Universidad de Lima

Escuela de Posgrado

Maestría en Dirección Estratégica de Contenidos

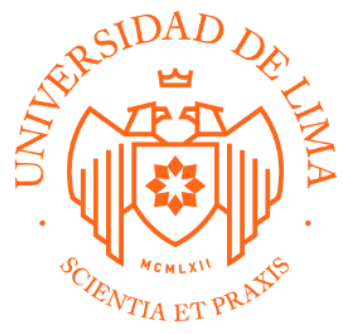

\title{
Proyecto de largometraje El infierno no es un lugar
}

Trabajo de investigación para optar el grado académico de Maestro en Dirección Estratégica de Contenidos

\section{Carlos Gustavo Quiroz Figuerola 20041982}

\author{
Asesora \\ Natalia Ames Ramello
}

Lima - Perú

Mayo de 2019 
Proyecto de largometraje El infierno no es un lugar 


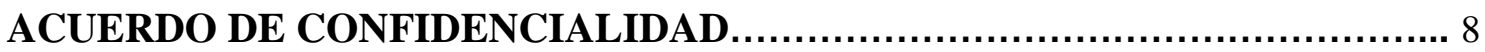

RESUMEN EJECUTIVO.................................................... 9

CAPÍTULO 1: PRODUCTO AUDIOVISUAL......................................... 11

1.1 Título de la Obra............................................... 11

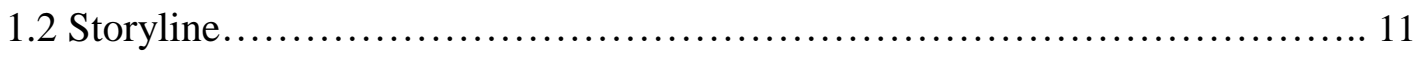

1.3 Sinopsis...................................................... 11

1.4 Género......................................................... 13

1.5 Motivación del director............................................... 13

CAPÍTULO 2: PROPUESTA VISUAL............................................ 16

2.1 Visual................................................................ 16

2.1.1 Argumento.................................................... 16

2.1.2 Comunicación y visión del mundo................................ 16

2.1.3 Dirección de fotografía........................................ 16

2.1.4 Dirección de arte.............................................. 19

2.1.5 Montaje...................................................... 21

CAPÍTULO 3: ANÁLISIS DE MERCADO.......................................... 22

3.1 Mercado general.................................................. 22

3.1.2 El mercado cultural ............................................. 22

3.1.3 El mercado mundial de cine.................................... 26

3.1.4 El sector cinematográfico en latinoamérica........................... 27

3.1.5 El mercado cinematográfico en el Perú............................ 32

3.2 Segmentos de mercado............................................. 36

3.2.1 El cine comercial.............................................. 36

3.2.2 El cine alternativo......................................... 39

3.3 Segmento objetivo.................................................... 41 
3.4 Características del Consumidor........................................ 42

3.4.1 Construcción del perfil del consumidor........................... 42

3.4.2 Perfil del espectador intermedio................................ 48

CAPÍTULO 4: ANÁLISIS DE LA COMPETENCIA.............................. 50

4.1 Competidores principales....................................... 50

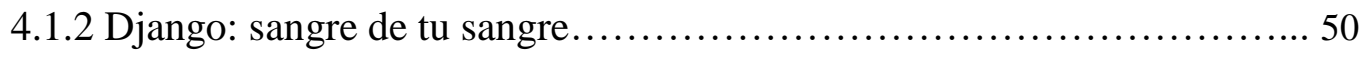

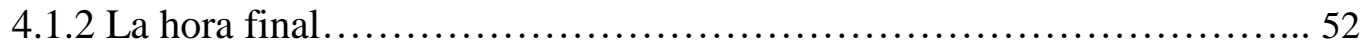

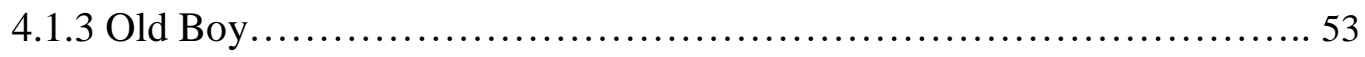

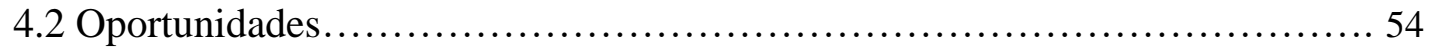

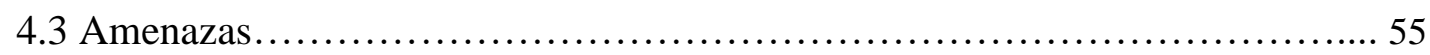

CAPÍTULO 5: MARKETING....................................................... 58

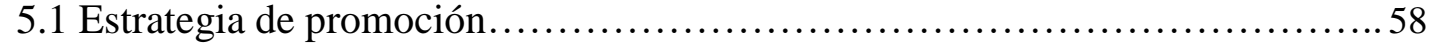

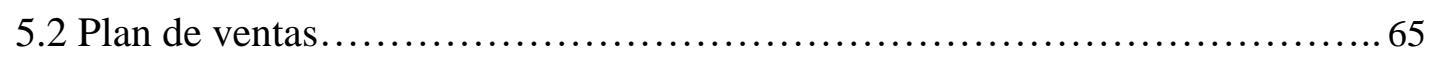

5.2.1 Distribución....................................................... 65

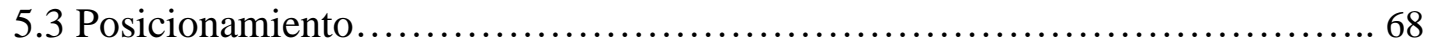

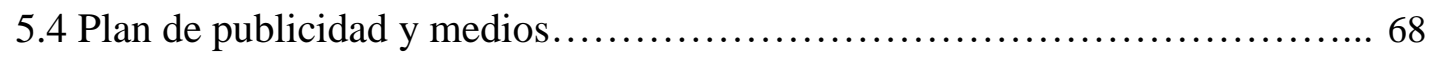

CAPÍTULO 6: OPERACIONES................................................. 71

6.1 Personal técnico................................................... 71

6.2 Personal artístico.................................................... 73

CAPÍTULO 7: FINANZAS......................................................... 76

7.1 Presupuesto detallado............................................ 76

7.2 Fuentes de financiamiento............................................ 80

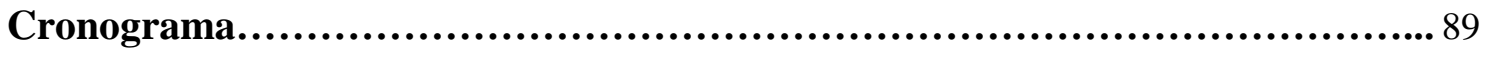

Bibliografía........................................................................ 90

Referencias.......................................................................... 92

Anexos.............................................................................. 94 


\section{ÍNDICE DE FIGURAS}

Figura 2.1: Paletas principales............................................ 17

Figura 2.2: Paletas secundarias............................................ 18

Figura 2.3: Paleta de arte primaria..........................................20

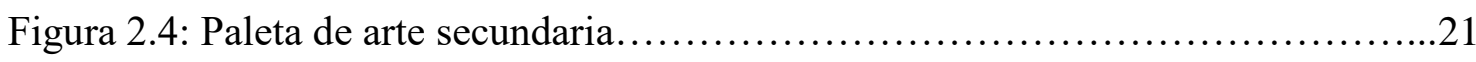

Figura 3.1: Segmentos de mercado en la economía naranja........................25

Figura 3.2: Segmentos de mercado especializados en la Economía Naranja............26

Figura 3.3: Principales indicadores de la industria cinematográfica latinoamericana...29

Figura 3.4: Participación de la Producción Cinematográfica de cada país en su propia Cartelera Comercial en América Latina 2014...................................... 32

Figura 3.5: Participación de empresas distribuidoras en el mercado latinoamericano según espectador..............................................................

Figura 3.6: Participación de las películas extranjeras y nacionales en el total de ingresos

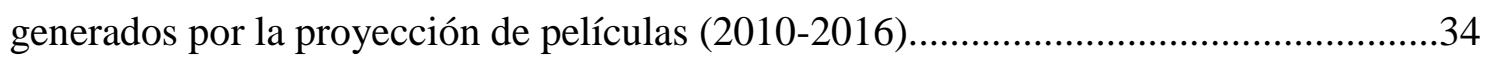

Figura 3.7: Número de producciones nacionales en los principales países de América

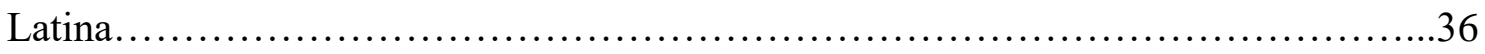

Figura 3.8: Características del consumidor intermedio...........................50

Figura 5.1: Parrilla de medios................................................69

Figura 6.1: Pietro Sibille. Fotogramas tomados de la película La hora fina .............73

Figura 6.2: Gerardo Zamora. Fotogramas tomados de la película Súper Condor........74 Figura 6.3: Amiel Cayo. Fotogramas tomados de la película Extirpador de idolatrías.74 


\section{ÍNDICE DE TABLAS}

Tabla 3.1: Contribución de la "economía naranja” a la economía de los países de América del Sur..............................................................24

Tabla 3.2: Producción mundial de largometrajes 20015-2013 ......................27

Tabla 3.3: Principales países productores de largometrajes 2005-2013...............28

Tabla 3.4: Principales indicadores de la industria cinematográfica $2014 \ldots \ldots \ldots \ldots \ldots . . . . .30$

Tabla 3.5: Principales indicadores de la industria cinematográfica en Perú 2007-

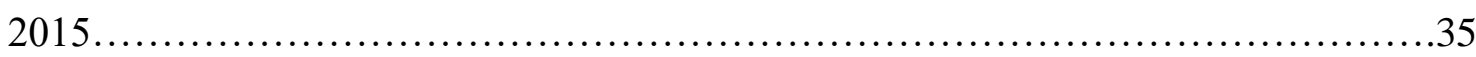

Tabla 3.6: Cinco películas peruanas galardonadas con premios internacionales más vistas en el Perú........................................................ 41

Tabla 3.7: Frecuencia de consumo de actividades..............................44

Tabla 3.8: Número de películas vistas al mes.................................45

Tabla 3.9: Frecuencia de consumo por género.................................46

Tabla 3.10: Tipo de película vista en los últimos meses.........................47

Tabla 3.11: Objetivo de ver películas.......................................48

Tabla 7.1: Presupuesto del proyecto....................................... 76

Tabla 7.2: Plan de financiamiento........................................... 80 


\section{ACUERDO DE CONFIDENCIALIDAD}

Me gustaría recibir una copia del Plan de emprendimiento audiovisual de la película El infierno no es un lugar producida por La Madeja con el único fin de invertir posiblemente en este proyecto. Reconozco que este Plan contiene información confidencial y es de propiedad exclusiva; cuya divulgación puede causar daño financiero a sus propietarios. Acepto no hacer copias de ninguna porción de él; no divulgar el Plan o cualquier parte de su contenido a terceros; y no hacer ningún uso del mismo que no sea para considerar la posibilidad de invertir en la película El infierno no es un lugar producida por La Madeja. Acepto devolver el Plan y cualquier documento de acompañamiento a los propietarios del mismo puntualmente, cuando haya completado mi revisión, cuando ya no tenga interés en considerar la posibilidad de invertir en él, cuando sea solicitado por sus propietarios, o lo que ocurra primero.

Nombre:

Firma:

Fecha: 


\section{RESUMEN EJECUTIVO}

Proyecto de largometraje El infierno no es un lugar producida por La Madeja.

\section{Concepto de proyecto:}

El proyecto es parte de la industria de entretenimiento dentro de la categoría audiovisual. Está dirigida a jóvenes adultos, en su mayoría universitarios, que buscan alternativas diferentes dentro del circuito comercial que no deslinden con sus preferencias con el cine de género.

El proyecto que se propone se inspira en las consecuencias que trajo consigo uno de los hechos más violentos de nuestra historia: el trauma social que generó la guerra contra Sendero Luminoso; guerra de la que las heridas hasta el día de hoy no han podido cicatrizar del todo. Además, toma como referente para su realización la estética del tratamiento de la venganza del Nuevo Cine Coreano que porta un valor diferencial ante su competencia en el mercado nacional.

\section{Situación actual:}

El proyecto actualmente se encuentra en la finalización de la escritura de la primera versión del guión. Con este primer borrador pretende que se vislumbre la estructura y el tratamiento que se pretende realizar. Sin embargo, es necesario ahondar más en la investigación y en la escritura de versiones que mejoren el relato hasta lograr consolidarlo a una versión que satisfaga al autor. Para ello, se postulará a convocatorias de talleres de revisión de guiónes en español y, más adelante, a concursos para conseguir fuentes de financiamiento para su realización.

Se pretende postular a los concursos promovidos por el Ministerio de Cultura del Perú para obtener estímulos económicos para la gestión del proyecto. También, se buscará ayuda mediante diferentes fondos internacionales, cuyo propósito es el fomento 
de estímulos económicos a través de la coproducción de la películas, como por ejemplo el Fondo Ibermedia o el Fondo Hubert Bals del Festival de cine de Róterdam, por dar algunos ejemplos que se adaptan y son accesibles al proyecto.

Como antecedente del proyecto, cabe mencionar que el guionista y director asignado para la realización de la película ha ganado en el 2018 el incentivo económico del Concurso Nacional de Proyectos de Cortometrajes y Videos Musicales promovido por el Ministerio de Cultura. Además, cuenta con una tesis de licenciatura sobre el tratamiento de la venganza en el cine de Park Chan-Wook, calificada como sobresaliente, lo cual lo hace un conocedor de la estética del cine coreano en el tratamiento de la venganza.

\section{Factores clave:}

Los factores clave de éxito del proyecto son el márketing y contar una propuesta que quiere diferenciarse de la oferta actual del mercado, a través del uso de los referentes visuales y tratamientos narrativos del cine coreano de los últimos años para adaptarlos a la realidad nacional . Se aplicará a través de una campaña transmedia que utilizá el recurso de simular los hechos de ficción con hechos reales con la finalidad de que genere expectativa por la trama y el tratamiento visual que se desarrolla en la película. 


\section{CAPÍTULO 1: PRODUCTO AUDIOVISUAL}

\subsection{Título de la Obra}

“El infierno no es un lugar."

\subsection{Storyline}

Lázaro logra huir de Ayacucho con la ayuda de su amigo Felipe tras la muerte de su novia, asesinada por Supay y el grupo senderista en el que militaban. Treinta años después, atormentado por sus recuerdos, vive obsesionado por encontrar a Supay para cobrar su venganza. Fortuitamente, se topa con la oportunidad y elabora un plan que lo lleva a descubrir que Supay es Felipe. De vuelta en Ayacucho, Felipe le revela que asesinó a su novia en venganza por la muerte de su hermana. Sin encontrar razón en sus motivos, cobra su venganza a costa de su propia vida.

\subsection{Sinopsis}

Lázaro junto a su novia Sofía entran a formar parte de la facción del PCP-Sendero Luminoso por su afinidad ideológica con el grupo durante sus años como estudiantes universitarios. Al realizar actividades con el grupo senderista, caen en cuenta que no es lo que ellos pensaban porque más allá de infundir una ideología a través del razonamiento, lo hacen por medio de la violencia e intimidación.

Deciden huir con ayuda de su amigo Felipe, pero son atrapados por los cabecillas Amaru y Machaqway, junto a sanguinario asesino enmascarado Supay. Quien asesina a Sofía en frente de Lázaro. En medio de eso, son emboscados por militares. Lázaro aprovecha el momento para escapar. Huye a la casa de sus padres, donde encuentra a su familia asesinada. Al enterrarlos, lo encuentra Felipe y lo convence de que huya de Ayacucho bajo la identidad de su hermano muerto. 
Treinta años después, Lázaro vive en Lima y trabaja como asistente de contabilidad. Pasa sus días atormentado por las muertes del pasado, con frustración e impotencia por no haber podido encontrar a los que le hicieron daño y esto lo obsesiona por buscar a Supay, quien sigue atormentando al pueblo de Vilca hasta la actualidad. Un día, yendo a realizar unos depósitos por encargo de la empresa donde trabaja, se encuentra fortuitamente con Machaqway, lo reconoce y lo sigue sin realizar los depósitos.

Llegan a la casa de Machaqway a quien sorprende y tortura para que le revele la identidad de Supay y Amaru. Solo le dice que Amaru es el que podría saber la identidad de Supay pero que no podrá llegar a él porque está en la cárcel. Al saber la identidad de Machaqway, Lázaro sabe en qué cárcel está encerrado y decide utilizar el dinero de los depositos para llegar a él.

Al volver a su oficina lo esperan el Señor Benites (su jefe) junto a la policía. Entre ellos está su amigo Felipe. Da la excusa que lo han asaltado y terminan por enviarlo prisión sin entregar nunca el dinero. En la cárcel se alía con una banda liderada por el taita Viejo Anselmo a cambio de parte del dinero robado. Con el tiempo desarrolla una gran confianza con él y le salva la vida. Por ello, el Viejo Anselmo lo ayuda a llegar a Amaruy organiza un motín. Lázaro logra llegar donde Amaru quien tampoco sabe quíén es Supay, pero le revela que fue Felipe el que lo delató cuando intentaba huír de Sendero. Confundido por la noticia, Lázaro se venga y huye de prisión para volver a Vilca a conseguir respuestas.

Lázaro llega al pueblo. Investiga el pasado de Felipe y descubre que tuvo una hermana llamada Isabela, que falleció años antes de que lo conociera en circunstancias misteriosas, y que sufría de abusos por parte de Sofí. Felipe llega a Vilca por una fotografía escolar enviada por Lázaro, donde se muestra a Isabela y Sofía como compañeras de promoción, con una inscripción para encontrarse donde asesinaron a su novía. Al estar en el lugar es sorprendido por Felipe y Supay, quienes hacen que pierda el conocimiento para llevarlo al pie de un acantilado.

Al recobrar el conocimiento, Lázaro está atado y le pregunta por qué lo traicionó. Felipe le explica que fue por venganza contra su novia Sofía, a quien culpaba por el suicidio de su hermana en el pasado, castigándola junto al pueblo y las personas que 
provocaron su muerte al humillarla, y él es parte de su venganza para que sufriera todo lo que el sufrió con la muerte de su hermana todos estos años. Que Supay es cualquier que sienta el deber de castigar al pueblo de Vilca por sus pecados. Siendo Felipe el que crea a Supay y quién mató a Sofía junto a su familia. Al escucharlo, Lázaro logra librarse de sus ataduras y asesina a otro Supay y deja inconsciente a Felipe.

Amanece en Vilca y Felipe está atado en la plaza con su máscara de Supay. Tiene una inscripción que lo señala como el asesino que ha atormentado a Vilca durante muchos años. La gente del pueblo sale extrañada de sus casas, se acercan a Supay, lo reconocen y empiezan lincharlo hasta matarlo. Lázaro moribundo contempla su venganza y muere tratando de encontrar el perdón..

\subsection{Género}

Policial, thriller, acción.

\subsection{Motivación del director}

El infierno no es un lugar es un proyecto que pretende hablar del resentimiento que se engendra en las sociedades como producto de la falta de percepción de la justicia entre sus individuos. Se trata comúnmente sociedades con falencias históricas que no han logrado cicatrizar las heridas causadas por un pasado violento, provocado por la discriminación, intolerancia y olvido de sus habitantes, y el tardío accionar del Estado para enmendarlo. Estos problemas están presentes en muchas sociedades, que tienen abandonados a algunos individuos, lo cual los expone a un accionar extremista para tratar de alcanzar la justicia con sus propias manos.

El Perú no está exento de estas falencias, como se puede apreciar a través de su historia, ejemplificadas por su reciente lucha contra la organización subversiva y terrorista Sendero Luminoso, que cometió actos atroces contra los peruanos durante los años 80s y 90s. Este período siempre ha llamado mi interés como peruano y realizador, por considerarlo un momento álgido de nuestra historia, que evidenció nuestros 
principales defectos como sociedad. Recordarlo constantemente es importante para disolver las diferencias que nos dividen y exaltar las virtudes que nos ayudaron a derrotar al mal que acarreamos en esos momentos difíciles del país.

Es por todo lo anterior, recurro nuevamente a desarrollar la temática senderista en uno de mis proyectos. Anteriormente escribí un guion con el nombre de La captura, que está basado en los acontecimientos narrados en el primer capítulo del libro Sendero: historia de la guerra milenaria en el Perú de Gustavo Gorriti. En él se cuenta el arresto del líder de Sendero Luminoso en enero de 1979, previo a su captura definitiva en 1992. El proyecto fue uno de los ganadores de Concurso Nacional de Proyectos de Cortometrajes y Videos Musicales de los Estímulos Económicos para la Cultura del 2018, y obtuvo un incentivo para su realización por parte de la Dirección del Audiovisual, la Fonografía y los Nuevos Medios del Ministerio de Cultura. Fue producido durante octubre de ese mismo año y actualmente en proceso de postproducción.

Otro elemento importante que me inspiró en desarrollar el presente proyecto parte de la admiración que tengo por el Nuevo Cine Coreano, que se ha venido desarrollando en estos últimos veinte años. Destacan, sobre todo, directores como Park Chan-Wook y Kim Ji-Woon, que muestran un estilizado tratamiento en sus películas al desarrollar la temática de la venganza, caracterizadas por una narrativa barroca que busca hibridar diversos géneros. Las películas de Park Chan-Wook son una fuerte influencia en la pasión que siento por el cine y fue esta admiración lo que me llevó a desarrollar una investigación de nombre El tutor silencioso: La venganza de las mujeres en el cine de Park ChanWook, con la cual obtuve mi título de licenciado por la Universidad de Lima en el 2017.

El interés por ambas temáticas son lo que motivan el proyecto El infierno no es un lugar. Lograr por medio de esta historia reflexionar sobre nuestra propia historia y ver cómo somos capaces de salir adelante por medio de nuestras virtudes como personas, pero sobre todo como sociedad. El infierno no es un lugar nos trata de advertir de que los pensamientos políticos fundamentalistas son tan nocivos como la venganza misma, aunque con el trasfondo de una historia de amor de alguien que busca la redención. 


\section{CAPÍTULO 2: PROPUESTA VISUAL}

\subsection{Visual}

\subsubsection{Argumento}

Luego de un pasado como senderista, Lázaro logra desertar del grupo con la ayuda de su amigo Felipe bajo la identidad de su hermano asesinado por el mismo grupo, pero con remordimientos por la muerte de su novia y su familia. Después de treinta años se encuentra preso de una vida rutinaria, acompañada de sentimientos de culpa, resentimiento y obsesionado por encontrar a Supay, el asesino de su novia. Fortuitamente se encuentra un día con Machaqway, uno de los responsables del asesinato de su novia, lo sigue y logra sacarle información sobre el paradero de los otros responsables para luego asesinarlos. Para ello, elabora un complejo plan de venganza que implica ir a prisión donde forzará a Amaru le revele que Felipe lo traicionó. La noticia lo desconcierta y vuelve al pueblo del que huyó para buscar respuestas. Ahí descubre que en realidad es Supay, el asesino de su novia y el cruel asesino de Vilca. Finalmente, logra llevar a Supay al pueblo de Vilca, donde es ajusticiado por los propios pueblerinos, con lo cual realiza su venganza a costa de su propia vida.

\subsubsection{Comunicación y visión del mundo}

Un ex senderista con un pasado tormentoso, afligido por el asesinato de su novia y su familia, decide tomar venganza treinta años después contra las personas que considera responsables, hasta involucrarse en la criminalidad para lograrlo. La venganza lo enrumba por un camino de violencia, pero no puede lograr la redención que tanto ansía. Eso es El infierno no es un lugar, un relato violento lleno de tragedia con clave dramática pero contado con las características de un thriller. Inspirado en la visión de la venganza del cine surcoreano, en donde se narran estrategias muy elaboradas para llevarla a cabo y que no logran la redención ansiada por sus personajes. No obstante, está contextualizado en el mundo del cine criminal. Es el reflejo de una sociedad con un pasado violento por discursos extremistas que permitieron aflorar resentimientos sociales que estuvieron por mucho tiempo invisibilizados, pero que hoy en día perduran con otra faceta: los altos índices de criminalidad e inseguridad que vive el Perú, como producto 
del olvido que tenemos como sociedad hacia nuestros ciudadanos. Lázaro intenta representar esa amnesia social y las consecuencias que pagan sus individuos.

\subsubsection{Dirección de fotografía}

Bajo este enfoque se trabajarán dos paletas de color principalmente, debido a que la historia está contada utilizando el recurso del flashback de los personajes. El pasado y el presente contarán con predominancia cromática de azules, verdes y blancos para construir una atmósfera fría que permita mostrar el clima apático, insensible y distante en el cual se mueven los personajes, pero con la diferencia de que para mostrar el pasado los colores se mostrarán con un contraste considerable. Independientemente de querer que se diferencie con este alto contraste el pasado del presente, también la intención es añadirle a este contexto una atmósfera hostil, adherente y con rasgos de dureza que aplasta a nuestro personaje.

Figura 2.1: Paletas principales

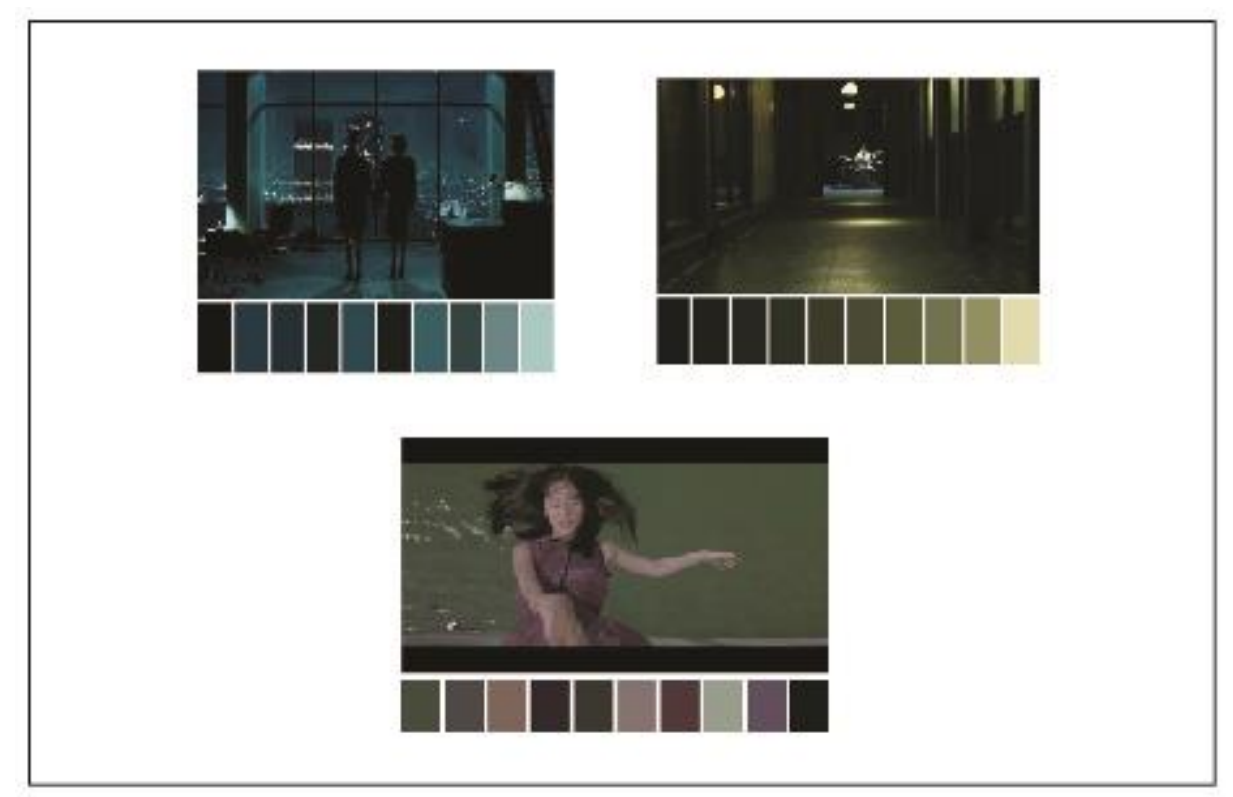

Fuente: Elaboración propia. Fotografías recuperadas de:

https://www.pinterest.es/pin/446419381809866164/

Adicionalmente tendrá una paleta de colores secundarios donde tendrían predominancia el rojo, el violeta y amarillo; proporcionados en pequeños toques, intentando mantener la sutileza, sobre todo en los escenarios nocturnos, añadiendo grandes diferencias. Además se pretende lograr con ellos ese clima fantástico y 
distorsionado del mundo de la venganza; mostrando a sus personajes como seres que se magnifican en la noche.

Figura 2.2: Paletas secundarias

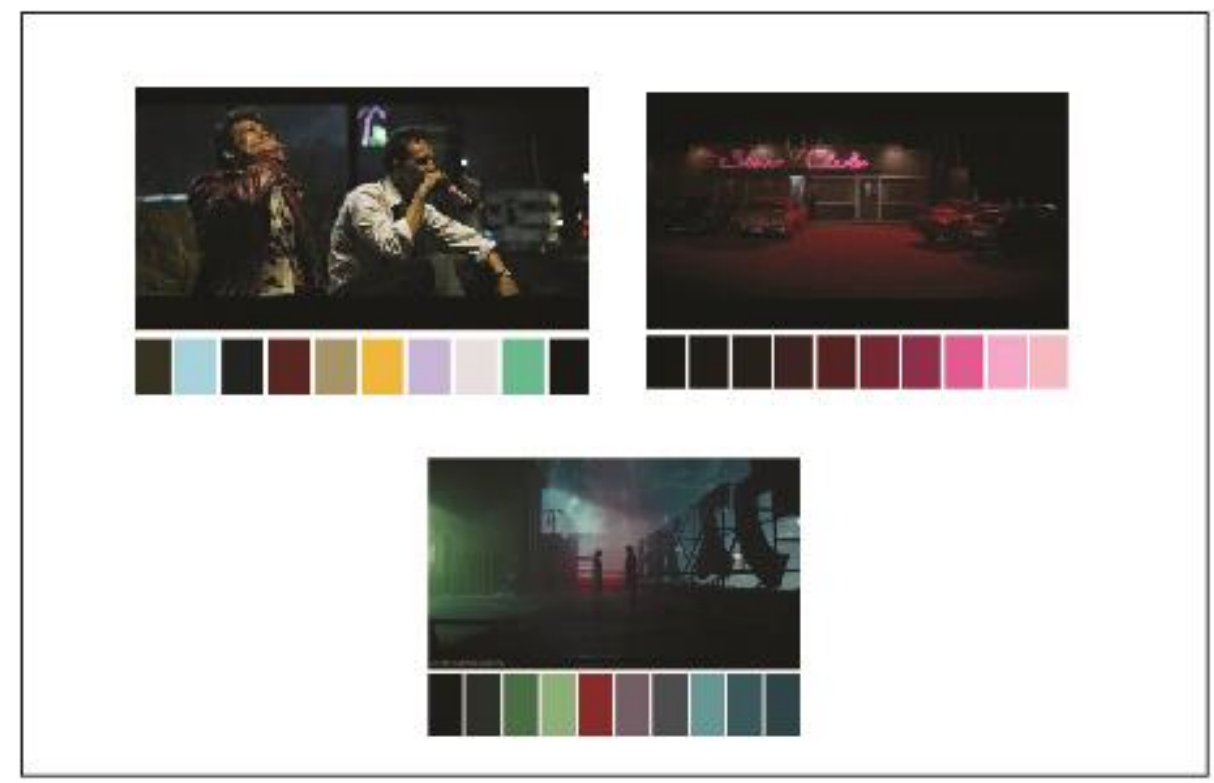

Fuente: elaboración propia. Fotografías recuperadas de:

https://www.pinterest.es/search/pins/?q=paletas\%20de $\% 20$ color\%20peliculas\&rs=type d\&term_meta[]=paletas\%7Ctyped\&term_meta[]=de\%7Ctyped\&term_meta[]=color\%7

Ctyped\&term_meta[]=peliculas\%7Ctyped

La predominancia de los verdes y azules se trabajará tratando de no afectar los tonos de piel de los personajes y, buscando la concordancia con el área de dirección de arte, se debe tener especial cuidado con el vestuario y los decorados de los escenarios debido a que al colorizar la imagen en estas tonalidades se podría afectar las otras tonalidades de los colores perseguidos.

Lo preponderante en la direccionalidad de la luz será lo cenital debido a que brinda mayores sombras en el rostro de los personajes con lo cual se busca, sumando los altos contrastes que tendrá en colorización, una mayor expresividad y, hasta cierto punto, dar una pequeña entonación siniestra a la gestualidad a los sujetos que se mueven en este mundo criminal y lo cual se justifica dentro del contexto del personaje. 
La intención de trabajar con dos paletas cromáticas es tener una marcada diferencia entre la vida monótona y atormentada de nuestro protagonista al inicio de la trama y su paso hacia el mundo de la venganza, exponiéndose a situaciones frenéticas para dar rienda suelta a sus instintos asesinos. En la primera solo se utilizarían luces fluorescentes con tonalidades frías para asociarlo con lo rutinario, aburrido y frívolo de su vida de oficinista en su día a día. En la segundo, cuando se sumerge en la venganza, se incorporan a estas tonalidades frías chispazos de color donde se utilizarán luces direccionales de tungsteno, HMI y fluorescentes, todas con filtro de color, que buscan crear atmósferas fantásticas alrededor de nuestro personaje.

Los lentes que se emplearán irán de angulares a normales con apertura de diafragma de $2.8 \mathrm{f}$ o menos para lograr poca profundidad de campo, sobre todo en el uso de primeros planos para mostrar difuso el entorno de los personajes y lograr captar por medio de la cercanía de la cámara gestos y expresiones que ayudarán a revelar sus conflictos más íntimos. Además, con los lentes angulares se busca dar una simulada deformidad a nuestros personajes en los primeros los planos, justificado por la distorsión a la que se someten en el submundo delincuencial, mostrándolos como seres corrompidos. En los planos más abiertos se brindará una mayor profundidad de campo para no perder la distorsión que da el angular y así "objetivar" a nuestro personaje principal dentro de un entorno distorsionado, independientemente si está en su faceta de oficinista o criminal, debido a que en ambos mundos Lázaro sea percibido bajo un matiz psicológico represivo y una atmósfera psicológica negativa de la cual no logrará zafarse.

En el tratamiento con la cámara será predominantemente el movimiento, manifestado en planos secuencia que ayudarán a brindar las tensiones propias del contexto desquiciado de la venganza en el que se desenvuelve nuestro personaje. Generando el suspenso necesario en acciones violentas que son el medio vertiginoso que Lázaro elige para consumar su venganza, mostrando un mundo insensible e inestable, de momentos instantáneos y vertiginosos con fugaces que no brindan ninguna garantía. Por otro lado, también se hará uso de los planos fijos agregando una doble composición por medio de enfoques y desenfoques en primer y segundo término, acompañados de paneos y trávellings ligeros y repentinos, para darle continuidad emocional al relato y no perder el movimiento que da la sensación de inestabilidad emocional y psicológica de nuestro personaje. 


\subsubsection{Dirección de arte}

Con la finalidad de mantener concordancia con la propuesta fotográfica y así lograr coherencia visual y narrativa en el relato, se trabajará con paletas cromáticas similares descritas líneas arriba con la intención de contribuir en el reforzamiento de las atmósferas frías que describen el clima emocional apático, indiferente y lúgubre del personaje en los momentos de su presente como oficinista. La segunda paleta donde se muestran colores más intensos, como los rojos, amarillos y violetas, es para crear una atmósfera fantástica del mundo criminal, donde finalmente se desenvolverá el personaje, evitando el uso de estos colores intensos para crear atmósferas cálidas, lo cual no es la intención del proyecto.

Figura 2.3: Paleta de arte primaria

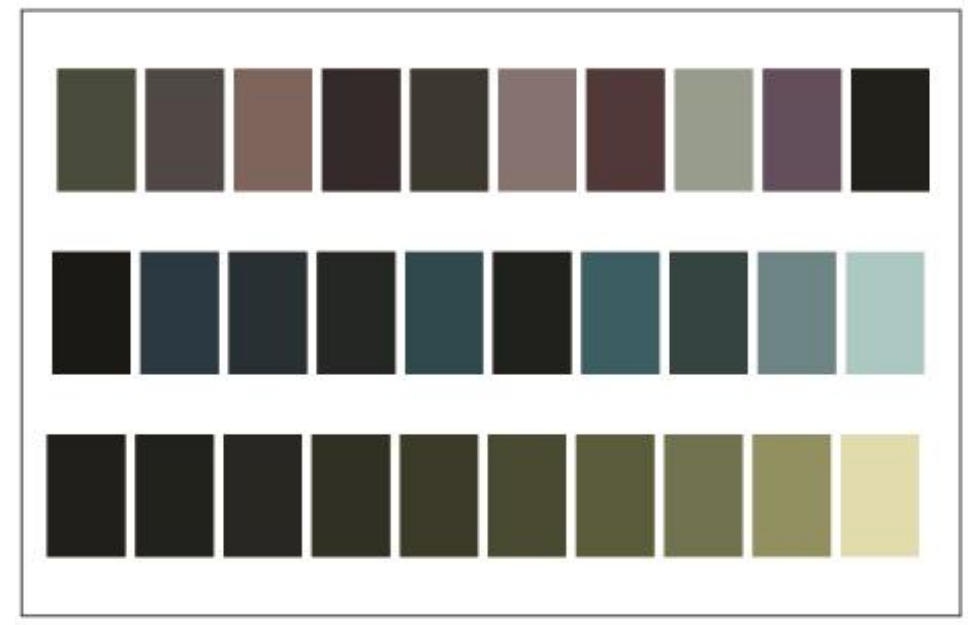


Figura 2.4: Paleta de arte secundaria

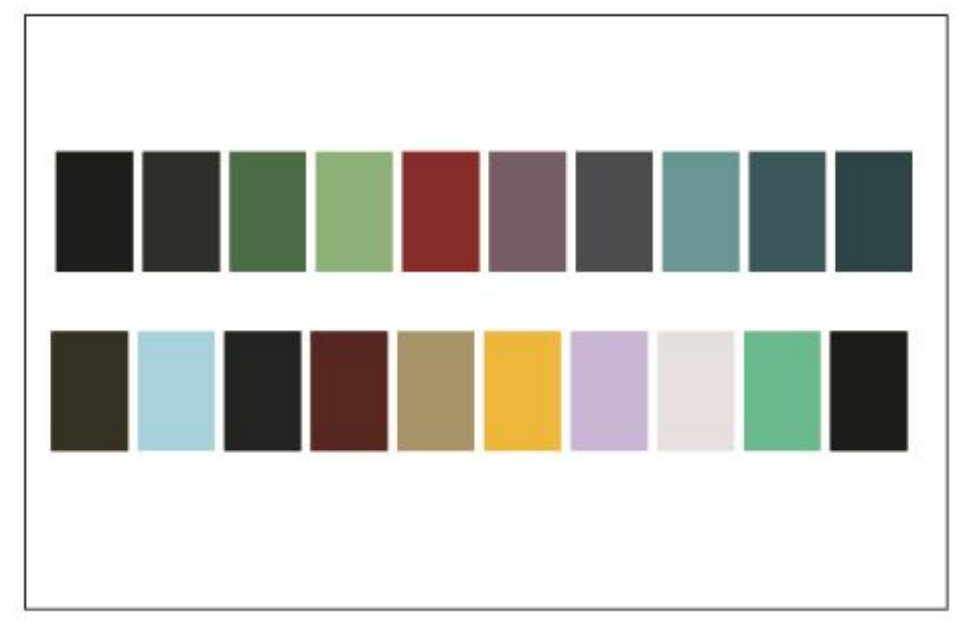

Fuente: Elaboración propia

Los escenarios de la primera parte, el momento de oficinista de nuestro personaje, deben ser pequeños, un ambiente donde la decoración debe darnos la sensación de opresión de oficina minúscula e improvisada, donde el acumulamiento de papeles y cajas muestran un ambiente deshumanizado y alienado. Si bien este ambiente muestra solo una parte de la historia, es importante notar el clima psicológico de abandono de Lázaro al encontrarse arrinconado en ese espacio por la clandestinidad en la que ha decido vivir. Los espacios en los que retorna a su vida criminal serán amplios y urbanos en su mayoría, y se destaca la indiferencia de sus ciudadanos atrapados en la rutina de su día a día. El decorado en estos espacios amplios será reducido para brindar la sensación de vacío en el que conviven los delincuentes, ya que se entiende su vida como algo fugaz donde el aislamiento es parte de su rutina.

En el vestuario se utilizará un traje que no le calza al personaje, lo cual nos da la impresión de descuido, como si el personaje no encaja donde está metido, y se mimetiza con ese ambiente desordenado en el que se desenvuelve. En el contexto criminal, el vestuario tendrá la característica de complementar la intensidad de los colores en el plano y lograr una coherencia con los colores de la paleta cromática. Además, los personajes envueltos en este mundo siempre tendrán algo blanco en su vestuario, que será difícil de mantener pulcro, como un simbolismo del contexto aberrante, absorbente y medio fantástico en el que se desenvuelven. En contribución a los vestuarios está el maquillaje, que pasará de un peinado que apenas parece sostenerse ordenado a mantenerse acomodado, y en todo momento tendrá un ligero oscurecimiento en sus párpados 
inferiores para simular ojeras, y dar la sensación de un constante agotamiento en nuestro personaje, sobre todo según se va introduciendo en su carrera delictiva para entonar su venganza.

\subsubsection{Montaje}

La presentación de la historia se distribuirá en diferentes espacios y tiempos en los que vive el personaje de forma alternada, que sigue una linealidad en el tiempo en que transcurren los sucesos. Es así como se mostrará el pasado del personaje para explicar qué motiva sus acciones en el presente. Para ello, se contará con el uso de flashbacks en el montaje, ayudados por el alto contraste que se subirá para estas escenas en la postproducción, sin que se afecte el raccord. 


\section{CAPÍTULO 3: ANÁLISIS DE MERCADO}

\subsection{Mercado general}

\subsubsection{El mercado cultural}

La economía naranja es el sector relacionado a los bienes y servicio artísticos y culturales a nivel mundial, denominada así por el Banco Interamericano de Desarrollo. Se definen como "el conjunto de actividades que de manera encadenada permiten que las ideas se transformen en bienes y servicios culturales, cuyo valor está determinado por su contenido de propiedad intelectual. El universo naranja está compuesto por: i) la economía cultural y las industrias creativas, en cuya intersección se encuentran las industrias culturales convencionales; y ii) las áreas de soporte para la creatividad" (Buitrago y Duque 2013: 40).

En el año 2011 el sector logró registrar US\$ 4.3 billones en todo el mundo, y generó más de 144 millones de puestos de trabajo, de los cuales 10.3 millones fueron generados en América Latina. "Este mismo sector viene registrando un incremento sostenido, tal es así que, durante la década pasada, entre los años 2002 y 2011, según cifras de la Conferencia de Naciones Unidas para el Comercio y el Desarrollo (UNCTAD), las exportaciones de bienes y servicios creativos crecieron en $134 \%$ en todo el mundo. Para el Perú se calcula para el 2011 que la Economía Naranja aportó en US\$4.7 mil millones de dólares involucrando a 660 mil trabajadores" (EGP, 2017:5). Según el Centro Nacional de Planeamiento estratégico (CEPLAN, 2016), el 2,6\% de nuestro PBI corresponde a la economía naranja, lo cual significa una gran oportunidad para el aprovechamiento de las industrias que la conforman. 
Tabla 3.1: Contribución de la economía naranja a la economía de los países de América del Sur

\begin{tabular}{|l|l|l|}
\hline País & $\begin{array}{l}\text { Contribución al PBI (miles } \\
\text { de millones de dólares) }\end{array}$ & $\begin{array}{l}\text { Contribución al empleo } \\
\text { (miles de trabajadores) }\end{array}$ \\
\hline Argentina & US\$17.08 & 550 \\
\hline Brasil & US\$66.87 & 1730 \\
\hline Colombia & US\$11.00 & 1160 \\
\hline Chile & US\$3.98 & 170 \\
\hline México & US\$ 55.01 & 5280 \\
\hline Perú & US\$4.72 & 660 \\
\hline
\end{tabular}

Fuente: BID (2013). Recuperado de Escuela de Gestión Pública (2017).

"Impacto económico del sector cinematográfico y audiovisual y análisis costobeneficio de la implementación del anteproyecto de la ley de la cinematografía y el audiovisual”. Lima, Perú: Universidad del Pacífico.

La economía cultural comprende actividades artísticas tradicionales e industrias creativas convencionales, además de aquellas actividades relativas a la construcción de un patrimonio cultural y su transmisión; y las industrias culturales comprende también a las industrias culturales convencionales y el grupo de creaciones funcionales, nuevos medios y software (Buitrago y Duque, 2013). Tanto la economía cultural como las industrias creativas conforman dos grandes segmentos de la economía naranja, donde las industrias creativas convencionales forman parte importante de ambos grupos que se definen como, según Buitrago y Duque (2013: pp), "actividades que proveen bienes y servicios basándose en los contenidos simbólicos artísticos y creativos, que pueden ser reproducidos y/o difundidos masivamente, y que son tradicionalmente reconocidas por tener una estrecha relación con la cultura". 
Figura 3.1: Segmentos de mercado en la economía naranja

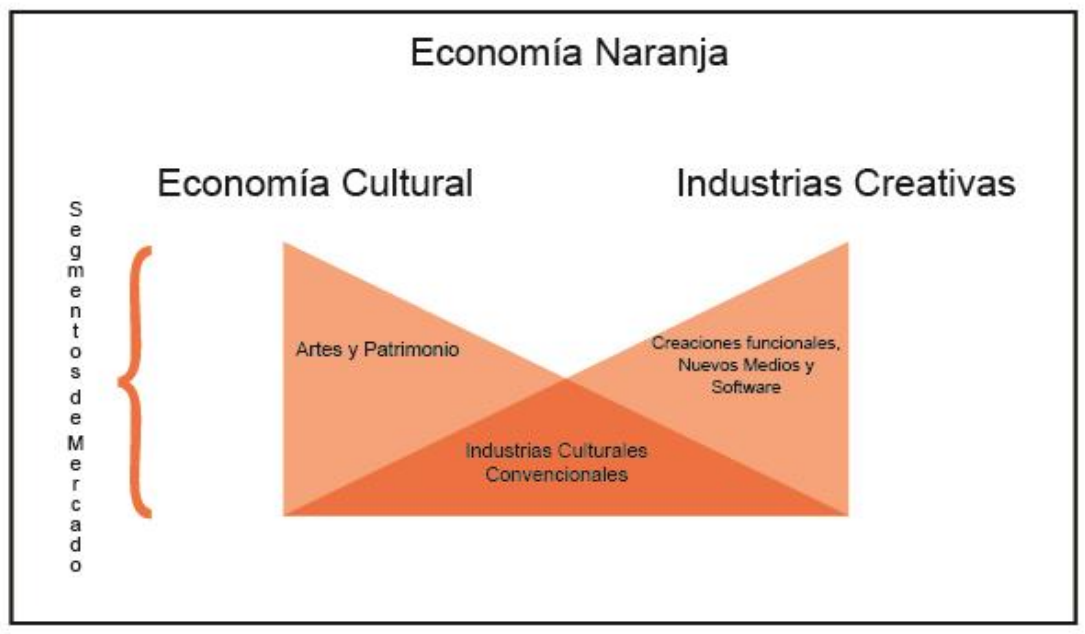

Fuente: elaboración propia con base en Buitrago y Duque (2013).

Las industrias culturales convencionales están conformadas por una gran variedad de sectores económicos, y se caracterizan por productos y servicios de producción intensiva, relacionados sustancialmente con el trabajo especializado; están altamente diferenciados y no cuentan con una estandarización. En ese ámbito no es común competir por volúmenes o precios, sino más bien por sus características únicas (Actividades económicas 2018). Este gran mercado está compuesto por las actividades editoriales, fonográficas y audiovisuales; en esta última se ubica el sector cinematográfico, televisivo y del video. 
Figura 3.2: Segmentos de mercado especializados en la economía naranja

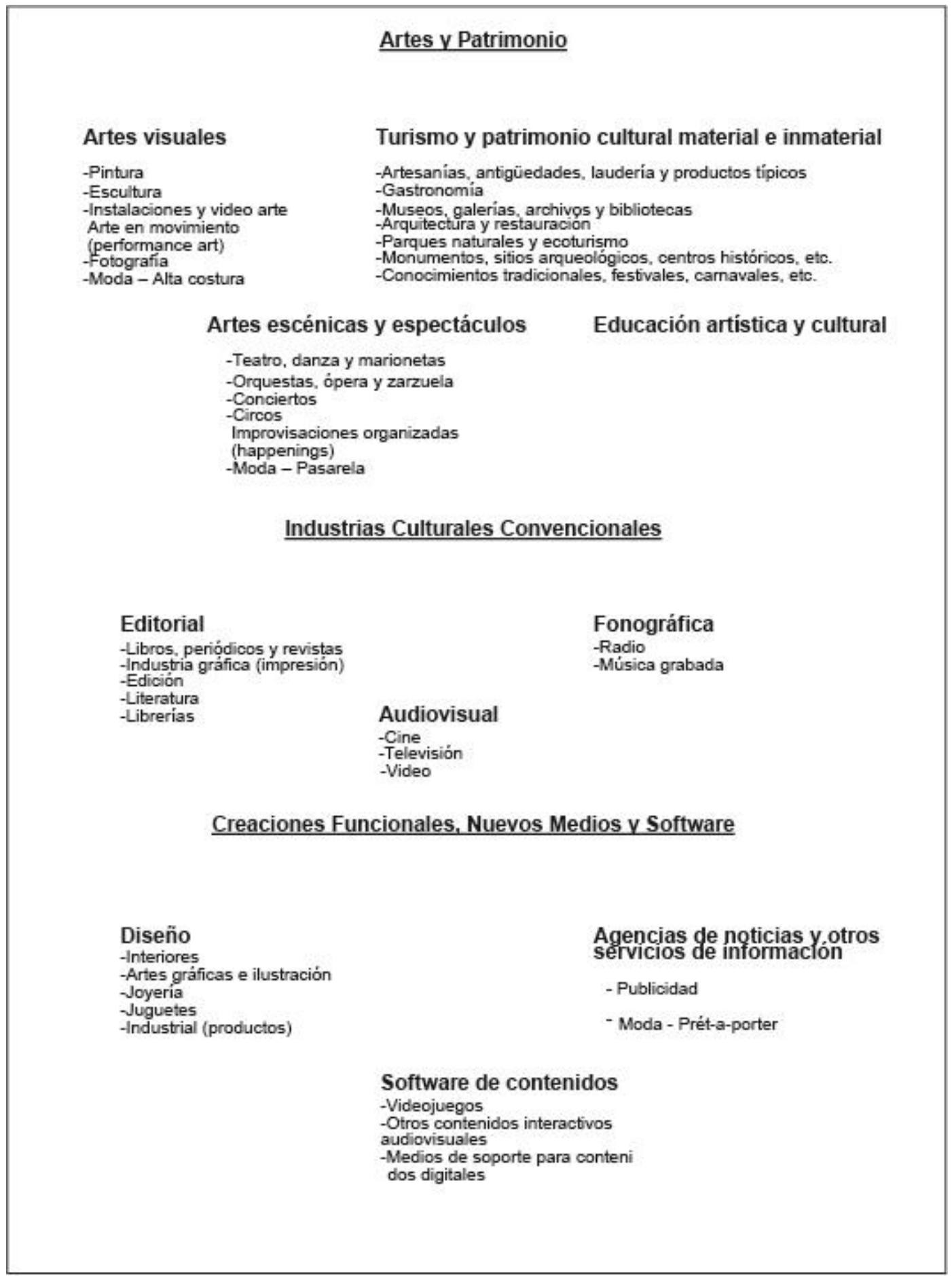

Fuente: elaboración propia con base en Buitrago y Duque (2013). 


\subsubsection{El mercado mundial de cine}

La producción cinematográfica mundial se ha caracterizado por un constante crecimiento durante los últimos años en cuanto al número de películas realizadas y estrenadas. También se muestra un dominio de cinco países en lo que se refiere a producción, consumo e ingresos, ya que aportan el 52\% de la producción cinematográfica mundial. En el 2013 el top cinco de naciones con mayor número de producciones a nivel mundial fueron India, China, Japón, Estados Unidos y Francia.

\section{Tabla 3.2: Producción mundial de largometrajes 20015-2013}

Fuente: Unesco for statistics (UIS) 2016. Adaptado por Manrique, Palomares y Villasante (2018).

La participación de estos cinco principales productores a nivel mundial se la han dividido

en

$\operatorname{los}$

últimos

conteos

\begin{tabular}{|c|c|c|c|c|c|c|c|c|c|}
\hline & $\mathbf{2 0 0 5}$ & $\mathbf{2 0 0 6}$ & $\mathbf{2 0 0 7}$ & $\mathbf{2 0 0 8}$ & $\mathbf{2 0 0 9}$ & $\mathbf{2 0 1 0}$ & $\mathbf{2 0 1 1}$ & $\mathbf{2 0 1 2}$ & $\mathbf{2 0 1 3}$ \\
\hline $\begin{array}{c}\text { Largome- } \\
\text { traje }\end{array}$ & 4,642 & 5,016 & 5,532 & 6,117 & 6,242 & 6,503 & 6,629 & 7,478 & 7,610 \\
\hline Paises & 95 & 89 & 96 & 100 & 100 & 94 & 90 & 88 & 86 \\
\hline $\begin{array}{c}\text { \% de los 5 } \\
\text { principales } \\
\text { productores }\end{array}$ & $\begin{array}{c}59.6 \\
\%\end{array}$ & $54.1 \%$ & $53.9 \%$ & $52.6 \%$ & $52.2 \%$ & $51.7 \%$ & $51.2 \%$ & $53.0 \%$ & $52.0 \%$ \\
\hline $\begin{array}{c}\text { Tasa anual } \\
\text { de } \\
\text { crecimiento }\end{array}$ & \multicolumn{2}{|c|}{$8005-2006$} & $\begin{array}{c}2006- \\
2007\end{array}$ & $\begin{array}{c}2007- \\
2008\end{array}$ & $\begin{array}{c}2008- \\
2009\end{array}$ & $\begin{array}{c}2009- \\
2010\end{array}$ & $\begin{array}{c}2010- \\
2011\end{array}$ & $\begin{array}{c}2011- \\
2012\end{array}$ & $\begin{array}{c}2012- \\
2013\end{array}$ \\
\cline { 2 - 10 } & $10.3 \%$ & $10.6 \%$ & $2.0 \%$ & $4.2 \%$ & $1.9 \%$ & $12.8 \%$ & $1.8 \%$ \\
\hline $\begin{array}{c}\text { Tasa de } \\
\text { crecimiento } \\
\text { 2005-2013 }\end{array}$ & \multicolumn{2}{|c|}{$63.90 \%$} \\
\hline
\end{tabular}

entre Estados Unidos, Francia, China, Japón, el Reino Unido e India. Esta última encabeza la lista cada año, por la mayor cantidad de producciones y por el crecimiento anual significativo de India, gracias a una industria establecida y solvente conocida como Bollywood. 
Tabla 3.3: Principales países productores de largometrajes 2005-2013

\begin{tabular}{|c|c|c|c|c|c|c|c|c|c|}
\hline Top 5 & 2005 & 2006 & 2007 & 2008 & 2009 & 2010 & 2011 & 2012 & 2013 \\
\hline 1 & $\begin{array}{l}\text { India } \\
1041\end{array}$ & $\begin{array}{c}\text { India } \\
1091\end{array}$ & $\begin{array}{l}\text { India } \\
1146\end{array}$ & $\begin{array}{l}\text { India } \\
1325\end{array}$ & $\begin{array}{c}\text { India } \\
1288 \\
\end{array}$ & $\begin{array}{c}\text { India } \\
1274\end{array}$ & $\begin{array}{l}\text { India } \\
1255\end{array}$ & $\begin{array}{l}\text { India } \\
1602\end{array}$ & $\begin{array}{c}\text { India } \\
1724 \\
\end{array}$ \\
\hline 2 & $\begin{array}{l}\text { EEUU } \\
872\end{array}$ & $\begin{array}{l}\text { EEUU } \\
673\end{array}$ & $\begin{array}{l}\text { EEUU } \\
789\end{array}$ & $\begin{array}{l}\text { EEUU } \\
773\end{array}$ & $\begin{array}{l}\text { EEUU } \\
751\end{array}$ & $\begin{array}{l}\text { EEUU } \\
792\end{array}$ & $\begin{array}{l}\text { EEUU } \\
819\end{array}$ & $\begin{array}{l}\text { China } \\
745\end{array}$ & $\begin{array}{l}\text { EEUU } \\
738 \\
\end{array}$ \\
\hline 3 & $\begin{array}{l}\text { Japón } \\
356 \\
\end{array}$ & $\begin{array}{l}\text { Japón } \\
417 \\
\end{array}$ & $\begin{array}{l}\text { China } \\
411\end{array}$ & $\begin{array}{l}\text { China } \\
422\end{array}$ & $\begin{array}{l}\text { China } \\
475\end{array}$ & $\begin{array}{l}\text { China } \\
542\end{array}$ & $\begin{array}{l}\text { China } \\
584\end{array}$ & $\begin{array}{l}\text { EEUU } \\
738 \\
\end{array}$ & $\begin{array}{l}\text { China } \\
638 \\
\end{array}$ \\
\hline 4 & $\begin{array}{l}\text { China } \\
411\end{array}$ & $\begin{array}{l}\text { China } \\
411\end{array}$ & $\begin{array}{l}\text { Japón } \\
417\end{array}$ & $\begin{array}{l}\text { Japón } \\
417\end{array}$ & $\begin{array}{l}\text { Japón } \\
417\end{array}$ & $\begin{array}{l}\text { Japón } \\
417\end{array}$ & $\begin{array}{l}\text { Japón } \\
417\end{array}$ & $\begin{array}{l}\text { Japón } \\
417\end{array}$ & $\begin{array}{l}\text { Japón } \\
417\end{array}$ \\
\hline 5 & $\begin{array}{l}\text { Francia } \\
240\end{array}$ & $\begin{array}{c}\text { Francia } \\
203\end{array}$ & $\begin{array}{c}\text { Francia } \\
228\end{array}$ & $\begin{array}{c}\text { Reino } \\
\text { Unido } \\
279 \\
\end{array}$ & $\begin{array}{c}\text { Reino } \\
\text { Unido } \\
313\end{array}$ & $\begin{array}{c}\text { Reino } \\
\text { Unido } \\
346\end{array}$ & $\begin{array}{c}\text { Reino } \\
\text { Unido } \\
299 \\
\end{array}$ & $\begin{array}{c}\text { Reino } \\
\text { Unido } \\
326 \\
\end{array}$ & $\begin{array}{c}\text { Francia } \\
270\end{array}$ \\
\hline
\end{tabular}

Fuente: Unesco for statistics (UIS) 2016. Adaptado por Manrique, Palomares y

Villasante (2018)

Se puede observar a India como la industria más grande por la cantidad de películas producidas por año, que se muestra muy por encima de sus demás competidoras. Sin embargo, tiene barreras como el idioma y las temáticas culturales en sus filmes que le impiden tener un espacio de distribución tan amplio como las películas estadounidenses y europeas que llegan, en su gran mayoría, a la cartelera comercial de los cinco continentes (Manrique, Palomares, y Villasante, 2018).

\subsubsection{El sector cinematográfico en Latinoamérica}

En los últimos años ha ido en aumento el optimismo hacia el sector cinematográfico y audiovisual, debido al constante incremento en los indicadores en toda la región, junto con el mercado mundial. Durante este período se instalaron más multicines y se incrementó el número de pantallas en la región, lo cual dio como resultado un mayor número de boletos vendidos y un incremento en la recaudación (Ministerio de Cultura 2016). 
Figura 3.3: Principales indicadores de la industria cinematográfica latinoamericana.

\begin{tabular}{|cc|}
\hline $12 \mathrm{mil}$ & $\begin{array}{c}\text { Pantallas } \\
\text { de muticines }\end{array}$ \\
\hline $\begin{array}{c}623.3 \\
\text { millones }\end{array}$ & Boletos \\
\hline $13.9 \%$ & $\begin{array}{c}\text { Cine latinoamericano } \\
\text { en mutticines }\end{array}$ \\
\hline 553 & $\begin{array}{c}\text { Estrenos } \\
\text { latinoamericanos }\end{array}$ \\
\hline 3 mill32 & $\begin{array}{c}\text { Dólares en } \\
\text { recaudacion }\end{array}$ \\
\hline
\end{tabular}

Fuente: Entidad de Gestión de Derechos de los Productores

Audiovisuales (2015). Recuperado de Ministerio de Cultura

(2016).

Según el Ministerio de Cultura (2016), el aumento en las salas de cine en la región es resultado de una inversión mayor por parte de cadenas internacionales de distribución y exhibición, ya que hay un aumento de $14 \%$ de pantallas de cine en la región, lo cual dio origen a la ampliación en el número de espectadores. Indicadores del 2014 colocan al Perú como el quinto país en la región con mejor infraestructura de exhibición cinematográfica (Ministerio de Cultura 2016). 
Tabla 3.4: Principales indicadores de la industria Cinematográfica 2014

\begin{tabular}{|c|c|c|c|c|c|c|}
\hline País & Pantallas & $\begin{array}{l}\text { estrenos de } \\
\text { largometraj } \\
\text { es }\end{array}$ & $\begin{array}{l}\text { estrenos de } \\
\text { largometraj } \\
\text { es nacionales }\end{array}$ & $\begin{array}{l}\text { estrenos de } \\
\text { largometraj } \\
\text { es } \\
\text { extrangeros }\end{array}$ & $\begin{array}{l}\text { Entradas } \\
\text { Vendidas } \\
\text { (millones de } \\
\text { boletos) }\end{array}$ & $\begin{array}{l}\text { Recaudació } \\
\text { n por } \\
\text { taquilla total } \\
\text { (millones de } \\
\text { dólares) }\end{array}$ \\
\hline Argentina & 867 & 436 & 167 & 269 & 45.6 & 247.4 \\
\hline Bolivia & 98 & 265 & 8 & 257 & 4.5 & 25.8 \\
\hline Brasil & 2833 & 387 & 114 & 273 & 155.6 & 833.7 \\
\hline Chile & 348 & 229 & 40 & 189 & 22.0 & 118.5 \\
\hline Colombia & 833 & 249 & 28 & 221 & 46.9 & 189.1 \\
\hline Ecuador & 300 & 177 & 17 & 160 & 14.5 & 56.8 \\
\hline México & 5678 & 330 & 68 & 262 & 240.3 & 832.6 \\
\hline Perú & 555 & 287 & 17 & 270 & 38.7 & 411.8 \\
\hline $\begin{array}{l}\text { Otros Países } \\
\text { latinoamericanos }\end{array}$ & 1280 & 1605 & 94 & 1511 & 55.3 & 416.6 \\
\hline total & 12792 & 3965 & 553 & 3412 & 623.3 & 3132.3 \\
\hline
\end{tabular}

Nota: La información presentada en el caso de Perú corresponde a la exhibición en pantallas de multicines.

Fuente: Elaboración propia a partir de Panorama Audiovisual Iberoamericano 2015-

Entidad de Gestión de Derechos de los Productores Audiovisuales (EGEDA); DAFO Ministerio de Cultura del Perú.

Además, el aumento de los multicines en la región mantuvo un correlato con los estrenos nacionales dentro de la cartelera comercial de cada país, lo cual produjo a la vez un mayor porcentaje de estrenos de cine latinoamericano en multicines. Cabe destacar que este aumento se dio principalmente en los países sudamericanos.

"Otros países que lograron ingresar mayor cantidad de largometrajes nacionales a la cartelera comercial local fueron Brasil con 114 y México con 68 títulos. Chile exhibió 40 de sus películas ese año. Perú y Ecuador lograron estrenar cada uno 
17 largometrajes nacionales, mientras que Bolivia estrenó 8. Los países que estrenaron menor cantidad de películas de producción local en su cartelera comercial fueron principalmente los países centroamericanos. Nicaragua ocupó el final de la lista con 3 películas nacionales en su cartelera comercial el 2014" (Ministerio de Cultura, 2016).

El incremento de estos factores nos permite vislumbrar un auge en el sector cinematográfico de la región. Entre los años 2010 y el 2014 aumentó en un 31.5\% el número de boletos vendidos, y se logró una recaudación que alcanzó los 13 millones de dólares. ${ }^{1}$ Dentro de la venta de esos boletos, es Argentina el país con mayor oferta de estrenos cinematográficos de la región, con 436 estrenos en el 2014, de los cuales 167 son producciones nacionales, y se convirtió también en el país con mayor porcentaje de estrenos nacionales dentro de su cartelera comercial con el 38.3\% (Ministerio de Cultura 2016). Cabe mencionar que esa situación se debe a la presencia de instituciones fuertes que promueven normas que fortalecen la producción y exhibición en la industria de ese país que lo ayudan a distinguirse de la región.

1 Datos obtenidos del Informe panorámico de las artes y las industrias culturales en el Perú Dirección General de Industrias Culturales y Artes / Sistema de Información de las Artes / Año 1 $n^{\circ} 2-2016$. 
Figura 3.4: Participación de la producción cinematográfica de cada país en su propia cartelera comercial en América Latina 2014.

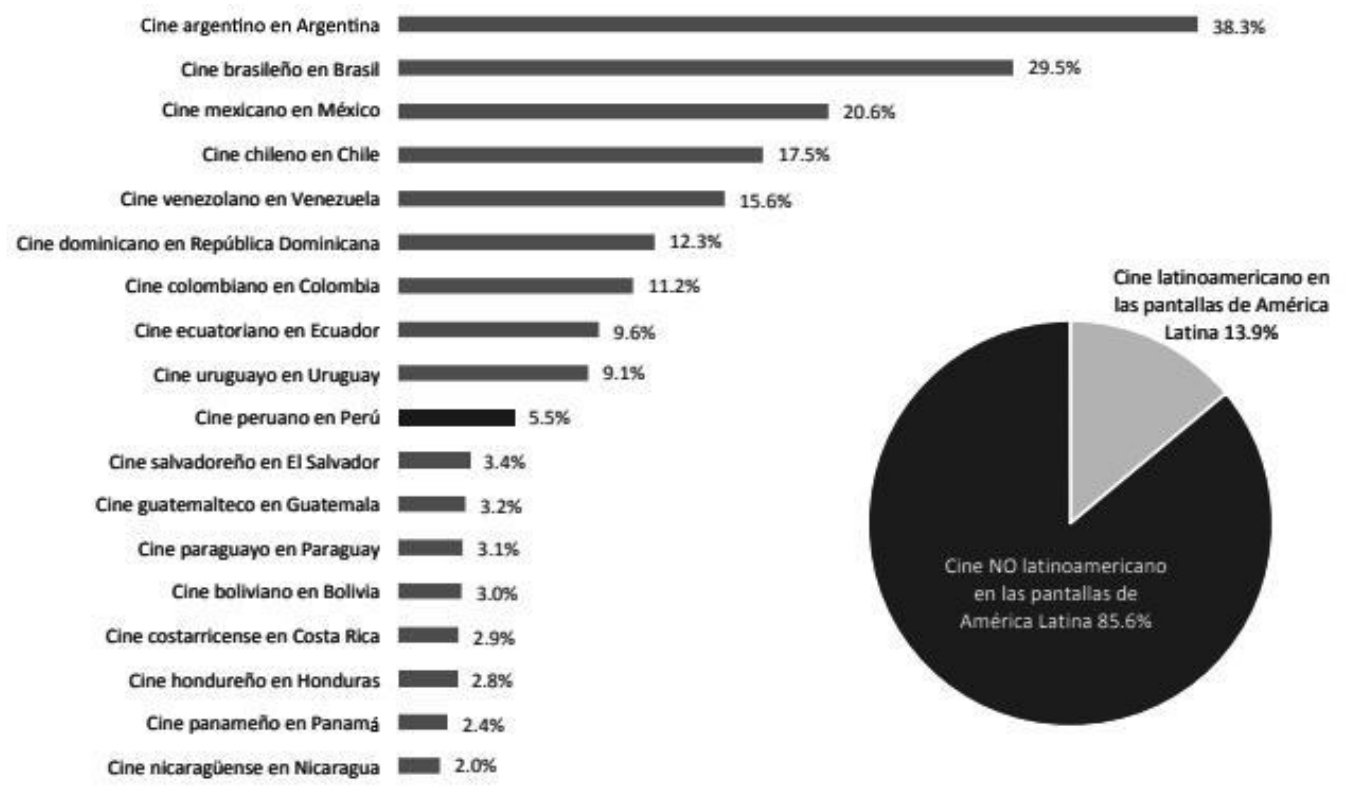

Fuente: Elaboración propia a partir de Panorama Audiovisual Iberoamericano 2015Entidad de Gestión de Derechos de los Productores Audiovisuales (EGEDA). Recuperado de DAFO - Ministerio de Cultura del Perú (2016).

A pesar del aumento de producciones nacionales estrenadas en su propia cartelera comercial, los porcentajes aún son incipientes si los comparamos con la gran cantidad de películas no latinoamericanas que llegaron a cartelera el 2014, como se puede apreciar en la gráfica (Gráfica 4). Esto se debe a que en la gran mayoría de países de la región no cuenta aún con instituciones sólidas y un marco normativo que promueva eficazmente la exhibición de sus producciones nacionales. Además, es notable la presencia de grandes empresas distribuidoras transnacionales, las majors, que dan prioridad de exhibición generalmente a películas de Hollywood. 
Figura 3.5: Participación de empresas distribuidoras en el mercado latinoamericano según espectador 2014 (porcentaje de boletos vendidos por películas distribuidas por cada empresa)

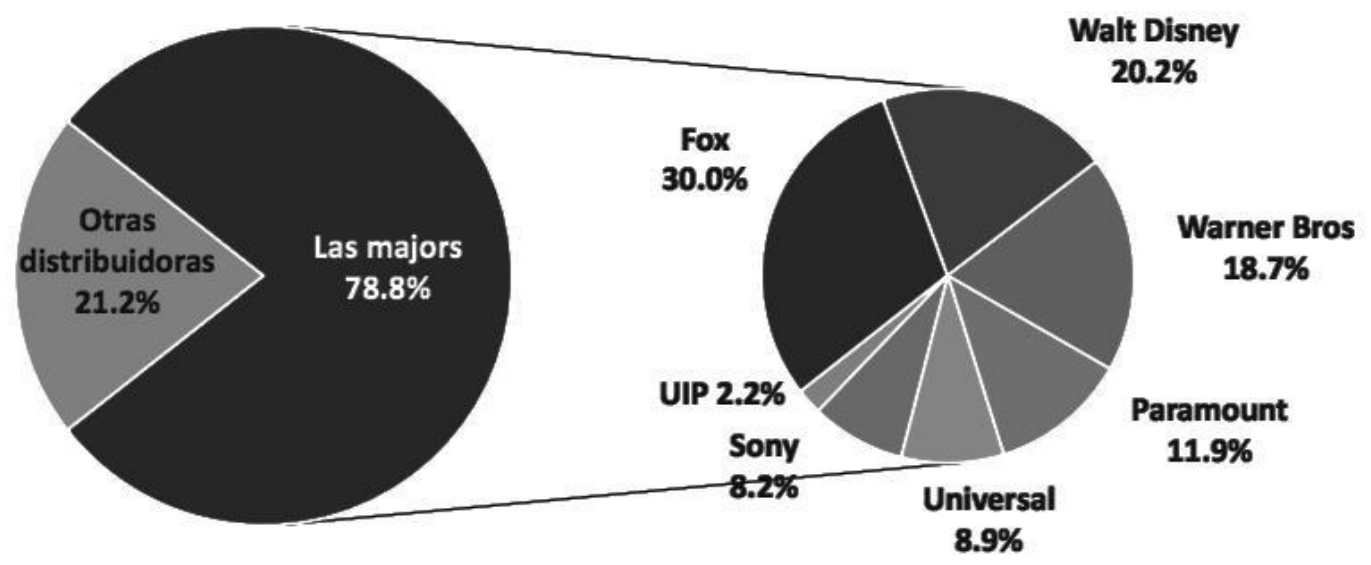

Fuente: Panorama Audiovisual Iberoamericano 2015 - Entidad de Gestión de Derechos de los Productores Audiovisuales (EGEDA). Recuperado de Dirección General de Industrias Culturales y Artes - Ministerio de Cultura (2016).

\subsubsection{El mercado cinematográfico en el Perú}

La tendencia de crecimiento que se viene proyectando en el sector no ha sido la excepción en el Perú; la taquilla nacional se ha caracterizado en estos últimos años por un incremento constante en la recaudación de boletería que corresponde al aumento de estrenos por año en la cartelera, lo cual permite avizorar un interés considerable en el consumo del sector. Según datos del Ministerio de Cultura (2016), la recaudación en soles por venta de boletos pasó de 285 millones de soles en el 2011 a 503 en el 2015, casi duplicando la recaudación en el lapso de 5 años.

Este incremento en la recaudación se corresponde con un progresivo aumento de estrenos durante los últimos años; entre los años 2007 al 2015 se pasó de 180 estrenos en multicines a 395 (Dirección General de Industrias Culturales y Artes - Ministerio de Cultura 2016). Dentro de esta demanda creciente se puede observar que son las producciones extranjeras las que dominan la escena de oferta cinematográfica en el país, ya que mantienen una participación del $90 \%$ de los ingresos brutos generados en los circuitos de cine de Lima y provincias (EGEDA-UP, 2017). En el siguiente gráfico se muestra esta evolución de los estrenos tanto nacionales como extranjeros en su participación evolutiva en la economía del sector. 
Figura 3.6: Participación de las películas extranjeras y nacionales en el total de ingresos generados por la proyección de películas (2010-2016).

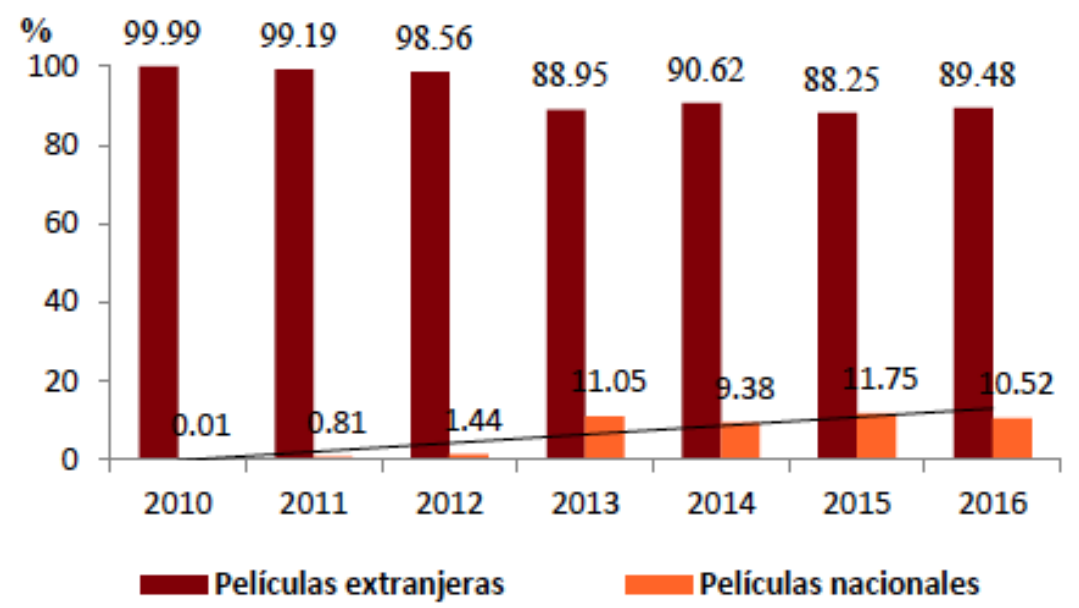

Fuente: Ministerio de Cultura-Cinedatos (2010-2016). Recuperado de EGEDA-UP (2017)

Sin embargo, esta creciente ola de estrenos de producciones internacionales en la cartelera nacional ha sido correspondida por un considerable aumento en los estrenos de producciones nacionales; según datos del Ministerio de Cultura (2016), durante el 2007 se estrenaron 4 películas peruanas mientras que en el 2015 pasó a 30 el número de estrenos. Esto demuestra un interés ascendente por parte de los espectadores peruanos hacia la producción nacional, y genera mucha expectativa en el crecimiento del sector y atrae a empresas que incrementan su inversión tanto en la infraestructura como en la producción. 
Tabla 3.5: Principales indicadores de la industria cinematográfica en Perú 2007-2015

\begin{tabular}{|c|c|c|c|c|c|c|c|c|c|c|c|}
\hline \multirow{2}{*}{ Año } & \multicolumn{2}{|c|}{$\begin{array}{l}\begin{array}{l}\text { Espacio de } \\
\text { exhibición }\end{array} \\
\text { d }\end{array}$} & \multicolumn{3}{|c|}{$\begin{array}{l}\text { Estrenos de largometrajes } \\
\text { en multicines }{ }^{2}\end{array}$} & \multicolumn{3}{|c|}{$\begin{array}{lcc}\begin{array}{l}\text { Entradas } \\
\text { multicines }\end{array} & \begin{array}{l}\text { vendidas } \\
\text { (millones }\end{array} & \begin{array}{l}\text { en } \\
\text { de }\end{array} \\
\text { boletos) } & & \end{array}$} & \multicolumn{3}{|c|}{ 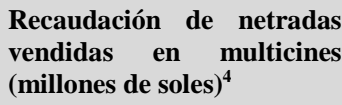 } \\
\hline & $\begin{array}{l}\text { Panata } \\
\text { llas en } \\
\text { multici } \\
\text { nes }\end{array}$ & $\begin{array}{l}\text { Microc } \\
\text { ines }\end{array}$ & $\begin{array}{l}\text { Nacion } \\
\text { al }\end{array}$ & $\begin{array}{l}\text { Extran } \\
\text { jero }\end{array}$ & Total & $\begin{array}{l}\text { Nacion } \\
\text { al }\end{array}$ & $\begin{array}{l}\text { Extran } \\
\text { jero }\end{array}$ & Total & $\begin{array}{l}\text { Nacion } \\
\text { al }\end{array}$ & $\begin{array}{l}\text { extranj } \\
\text { ero }\end{array}$ & Total \\
\hline 2007 & 291 & 32 & 4 & 176 & 180 & 0.2 & 16.2 & 16.5 & 1.6 & 122.0 & 123.6 \\
\hline 2008 & 291 & 32 & 10 & 185 & 195 & 0.6 & 18.0 & 18.5 & 4.3 & 152.4 & 156.7 \\
\hline 2009 & 299 & 32 & 7 & 192 & 199 & 1.0 & 21.3 & 22.2 & 8.0 & 194.6 & 202.6 \\
\hline 2010 & 346 & 32 & 9 & 205 & 214 & 0.1 & 22.8 & 22.9 & 0.8 & 218.4 & 219.3 \\
\hline 2011 & 396 & 36 & 9 & 238 & 247 & 0.2 & 29.3 & 29.6 & 2.1 & 290.2 & 292.4 \\
\hline 2012 & 425 & 36 & 9 & 239 & 248 & 0.5 & 30.6 & 31.1 & 4.5 & 321.7 & 326.2 \\
\hline 2013 & 474 & 36 & 13 & 276 & 289 & 4.0 & 30.2 & 34.2 & 41.3 & 327.5 & 368.7 \\
\hline 2014 & 555 & 36 & 17 & 270 & 287 & 3.8 & 34.8 & 38.7 & 39.4 & 372.4 & 411.8 \\
\hline 2015 & 554 & 36 & 30 & 365 & 395 & 5.6 & 40.4 & 46.1 & 59.2 & 444.8 & 504.0 \\
\hline
\end{tabular}

Fuentes: Dirección del Audiovisual, la Fonografia y los Nuevos Medios; Cinedatos (2007-2014); César Díaz (2015) y Red de Microcines del Grupo Chaski (2016).

Recuperado de Dirección General de Industrias Culturales y Artes - Ministerio de Cultura (2016).

En la tabla (tabla 3.4) se puede apreciar que se pasó de 4 películas estrenadas en el año 2008 a 30 en el 2015, sin contar estrenos en festivales de cine ni los espacios alternativos de exhibición. Este avance sustancial se debe, según Hendrickx (Perspectivas y posibilidades de crecimiento del cine peruano en el contexto mundial 2010), a que el número de realizaciones y estrenos en el país ha ido en aumento debido a dos factores primordiales. El primero corresponde a un cambio tecnológico en el sector, por el cual ya no se requiere que las películas sean rodadas en formato tradicional. A esto se ha hecho referencia en Bedoya 2015, al señalar la introducción del formato Digital Video (DV) y la cámara HD de alta definición como innovaciones que han impulsado el cine

\footnotetext{
${ }^{2}$ Se incluye a largometrajes de producción nacional, coproducción internacional y producción de las regiones del país con una duración de más de 75 minutos

${ }^{3}$ No se consideran estrenos en festivales de cine ni espacios alternativos de exhibición.

${ }^{4}$ No se considera la recaudación en microcines, cineclubes ni festivales.
} 
independiente, documental y "autogestionado". Estos formatos permiten la transferencia de datos de imágenes a formato computarizado (Cf. EGP-UP 2007).

Estos números traen consigo optimismo para la industria nacional; sin embargo, aún son incipientes en comparación con los demás países de la región.

Figura 3.7: Número de producciones nacionales en los principales países de América Latina

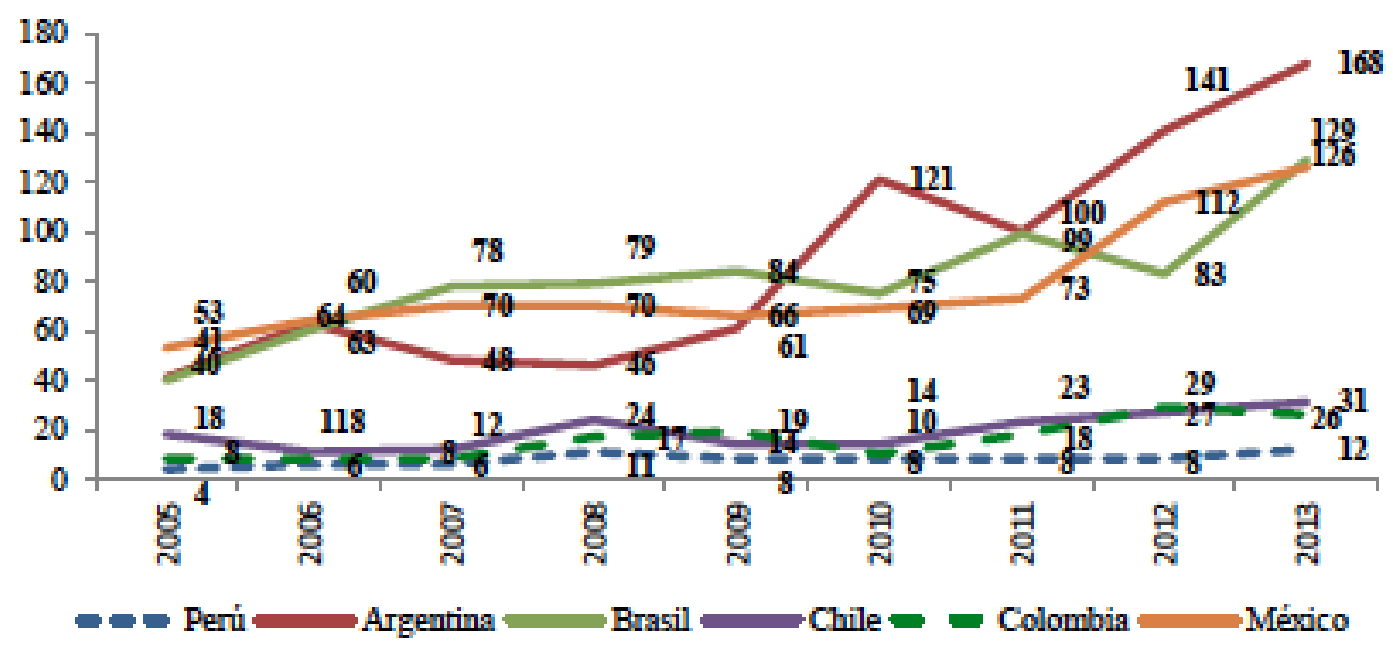

Fuente: UNESCO (2015). Recuperado de EGP-UP 2017.

El EGP-UP 2017 afirma, según datos del Ministerio de Cultura, que, a pesar de la crisis la crisis experimentada en el $2009^{5}$, entre 2011 y 2015 fueron 82 películas las que llegaron a salas comerciales; lo cual representa un poco más del $49 \%$ de las películas producidas y exhibidas a nivel nacional. Sin embargo, este aumento significativo no contabiliza otras producciones nacionales por estar ausentes en las principales salas del país. Ese es el caso de las producciones nacionales del denominado cine regional. Películas producidas fuera de Lima y que en su gran mayoría se exhiben en auditorios, losas deportivas, colegios y otros lugares de gran afluencia de público (Ministerio de Cultura 2016).

\footnotetext{
${ }^{5}$ Según (Bedoya 2015), este año mostró los peores resultados económicos para el cine peruano. De los 31 millones de espectadores que acudieron a salas de cine en el Perú, solo 472 mil lo hicieron para ver películas peruanas. Recuperado de EGP-UP (2017).
} 


\subsection{Segmentos de mercado}

El mercado peruano se rige actualmente por dos principales tendencias que ofrece la cartelera nacional. Por un lado, está cine comercial, enfocado tanto en un público masivo como en espectadores con gustos más exigentes. En la mayoría de los casos, estas películas fueron realizadas para obtener la mayor recaudación posible y por ello cuentan costosas campañas publicitarias. Por otro lado, está el cine alternativo, que ofrece una gran diversidad de películas provenientes de diferentes cinematografías y enfocadas en resaltar lo artístico. Se muestran en circuitos para un público más restringido y sofisticado.

\subsubsection{El cine comercial}

Está conformado en gran medida por películas que tienen como objetivo ser de consumo masivo y esperan ser éxitos de taquilla. Su principal finalidad es la recaudación monetaria, y dejan de lado, en muchos casos, la exploración artística y la complejidad en las temáticas. A las películas con estas características se les denomina blockbusters. Son producidas generalmente por las grandes productoras hollywoodenses, también llamadas majors, para vender un gran número de boletos tanto en los Estados Unidos como en el resto del mundo; y el Perú no es la excepción.

En el 2018, cuatro de las cinco películas más vistas en el país han sido producciones procedentes de esa cinematografía: Avengers: Infinity Wars, Jurassic World: Fallen kingdom, Incredibles 2 y Hotel Transylvania 3; siendo la primera de ellas la que actualmente se considera la película más taquillera de la historia del Perú. Según datos de Maykoll Calderón (2018) ${ }^{6}$, de las 25 películas más vistas del 2018, 23 son de procedencia hollywoodense, 3 del Reino Unido y 4 producciones peruanas, lo cual deja en claro el predominio de estas producciones en las preferencias del público nacional. En términos de porcentajes, según Jaime Akamine (2017), en promedio se estrenan en la cartelera peruana 250 títulos al año, de los cuales entre el $65 \%$ y $85 \%$ son de origen hollywoodense; el 12\% de cinematografías europeas como el Reino Unido, Francia y

${ }^{6}$ El Comercio, “Año 2018: Estas Fueron Las Películas Más Vistas Por Los Peruanos [FOTOS]." El Comercio, El Comercio, 29 Dec. 2018, elcomercio.pe/luces/cine/cine2018-son-peliculas-vistas-peruanos-noticia-592248 
España; poco del cine peruano con $12 \%$; y casi nada de cinematografías provenientes de Latinoamérica, Asia y África.

También encontramos producciones nacionales dentro del cine comercial del país, dentro de las cuales destacan las comedias nacionales encabezadas por el éxito de la productora Tondero con Asu Mare y sus secuelas, que durante los últimos cinco años ha mantenido sus producciones dentro de los filmes más vistos por los peruanos, compitiendo a la par con las grandes producciones hollywoodenses y de otras cinematografías. Esto ha dejado claro que el género cómico marca actualmente una tendencia en las preferencia de los espectadores peruanos al momento de elegir producciones nacionales. De las cinco películas nacionales más exitosas en taquilla, todas son comedias, de las cuales cuatro cuentan con más de un millón de espectadores (Cinencuentro 2017). Estas películas son altamente competitivas, y se pueden considerar blockbusters.

La fórmula recurrente de estos filmes tiene aspiraciones masivas y se caracteriza por traer figuras de la televisión nacional y contar temáticas simples con elementos que conectan con la cultura popular del país. Estos recursos pueden ser los causantes de que estas producciones no cuenten con el mismo éxito fuera de nuestras fronteras. Otro factor importante que considerar, sin desmerecer su preferencia por los peruanos, es que son las películas con menos restricciones y se pueden disfrutar tanto en grupo como en familia. Según Jorge Licetti, "Las películas que más les gustan a los peruanos son las comedias familiares. Si conjugas ambos elementos, aquí obtienes una combinación muy potente. Seguido a ello, las cintas de superhéroes son muy valoradas" (entrevista recuperada de https://gestion.pe/tendencias/preferencias-espectador-peruano-tipo-peliculas-ven$\underline{136703)}$.

Otros géneros que han alcanzado cifras interesantes durante los últimos años son el terror y el drama, y se han colocado entre las preferencias de los espectadores peruanos. Las películas de terror, independientemente de la calidad de las mismas, indican la posible tendencia del público hacia otro tipo de películas centrado en las cifras. No obstante, en los últimos tres años la cantidad de espectadores del género ha ido decayendo significativamente tanto como su producción. Esto se puede deber a la baja calidad en realización y guion de las mismas, y el excesivo recurso al found footage, con lo que se 
ha llegado a la fatiga del público. El 2014 fue un gran año para las películas de terror peruanas en términos de taquilla, los filmes lograron más de un millón de espectadores con cuatro estrenos ese mismo año. Con ello se colocaron como un género que atraía la atención de los espectadores gracias a las cifras que lo solventaban. Sin embargo, no se supo retener el interés dado que en los años siguientes la caída fue significativa.

Observando la cartelera que se ofrece en el circuito comercial, principalmente en los multicines de las principales cadenas como Cineplanet, UVK, Cinemark y Cinépolis, se percibe un predominio de los blockbusters y otras películas procedentes de Hollywood, aunque también cuentan con la presencia de algunas películas que diferencian estos cines según su cartelera. Claro que esto se da en una menor proporción y depende mucho de la ubicación de los cines por distritos, lo cual demuestra que hay diversidad de gustos entre sus públicos. Podríamos agruparlos en tres grandes segmentos:

a) Público con preferencias por los blockbusters nacionales e internacionales: conformado por una gran mayoría de espectadores que consumen películas de superhéroes y las grandes comedias nacionales. Van al cine con la mera intención de consumir producciones de entretenimiento ligero y en la mayoría de los casos en compañía de familiares y amigos. Consumen películas como Avengers: Infinity war, Black Panther, ¡Asu Mare! 3, Locos de Amor, etcétera.

b) Público con preferencias por el terror, el policial y thriller: En su mayoría consume producciones provenientes de Hollywood y en casos especiales de cinematografías de otra nacionalidad. También muestran un notable interés por producciones nacionales que han explorado el género, pero en los últimos tres años esta tendencia ha estado en caída. Es un público que se caracteriza por buscar emociones fuertes y normalmente van en compañía de amigos. Las películas con este contenido tienen gran acogida en cines ubicados en el cono norte y sur de Lima. Consumen películas como La Monja, Annabelle 2, Cementerio general, Django: sangre de tu sangre, Caiga quien caiga, etcétera.

c) Público con preferencias por el cine independiente o de autor: Es un público minoritario en el circuito comercial que busca propuestas diferentes o siguiendo sus gustos por un director. En su gran mayoría 
provienen del mercado norteamericano, pero también de otras cinematografías que logren llegar a la cartelera comercial. Van al cine solos o en pareja y visitan cines como Cineplanet Alcázar, Cinemark Jockey Plaza, UVK Platinum de San Isidro, UVK C.C. Chacarilla. Consumen películas como Moonlight, Manchester by the Sea, NN: Sin identidad, La hija de la laguna, etcétera.

\subsubsection{El cine alternativo}

Por otro lado, está el cine alternativo, que se caracteriza por películas que buscan explorar el lado artístico del cine, con temáticas diferentes caracterizadas por un complejo grado de elaboración. En este cine no se priorizan las preferencias masivas de los espectadores para encontrar un éxito monetario. Los espectadores que gustan de estas películas priorizan el valor artístico antes que un entretenimiento ligero, y difícilmente las encuentran en las salas comerciales debido a que no suelen ser rentables y son consumidas, en su mayoría, en circuitos especializados, como festivales, centros culturales, microcines y cineclubs. No tienden a preferir cinematografías de alguna nacionalidad en específico, lo cual permite valorar una mayor apertura en la exploración de diversas producciones. Les interesa la crítica especializada y son influenciados por ella, tanto como el boca a boca entre el público que gusta de este cine. Por ser un público cinéfilo son exigentes en sus gustos, y las distancias y horarios pueden no ser impedimentos muchas veces.

Los festivales especializados son las ventanas más importantes con las que cuentan los espectadores que gustan del cine alternativo, caracterizados por contar con películas independientes y con un mayor carácter autoral. Entre los más influyentes están el Festival de Cannes, el Festival de Venecia y el Festival de Berlín en Europa; el Festival Internacional de Cine Busan en Asia; el Festival Internacional de Cine de Toronto y Festival de Cine de Sundance en norteamérica; y el BAFICI y el Festival Internacional del Nuevo Cine de la Habana en Latinoamérica. Muchas de las películas galardonadas en estos festivales son las que alimentan la exhibición del circuito especializado nacional.

A nivel nacional, el festival con mayor alcance en número de espectadores es el Festival de Cine de Lima organizado por el Centro Cultural de la PUCP. En él se 
congregan un gran número de espectadores para acceder a películas que normalmente no encontrarían dentro de la cartelera nacional, tanto en producciones extranjeras como en nacionales. Algunos de los títulos traídos por el festival pasan al circuito de la cartelera comercial, debido al interés generado por el boca a boca que logró concentrar una cantidad interesante de espectadores en las salas de los festivales. Sin embargo, al igual que muchos festivales organizados en el país y el resto del mundo, la venta de tíckets no logra cubrir los costos de los festivales, y el Festival de Cine de Lima no es la excepción.

Al igual que los festivales, las películas del cine alternativo pocas veces resultan rentables para sus productores debido a las características de su público selectivo, ya que su mayor valor es el empeño artístico, y los reconocimientos y premios nacionales e internacionales que pueda lograr. Muchas de las películas peruanas que inician su exhibición en estos circuitos festivaleros difícilmente logran superar los 100,000 espectadores en el circuito comercial, a pesar de haber sido reconocidas o premiadas en el extranjero en festivales importantes. La única película peruana reconocida en el extranjero que superó los 100,000 espectadores en la cartelera comercial fue La teta asustada de Claudia Llosa, y gran parte de este arrastre se debió a su nominación al Oscar, premio con gran llegada en el público peruano.

Tabla 3.6: Cinco películas peruanas galardonadas con premios internacionales más vistas en el Perú

\begin{tabular}{|c|c|}
\hline Título & Número de espectadores \\
\hline La teta asustada & 249340 \\
\hline El evangelio de la carne & 61233 \\
\hline Madeinusa & 53000 \\
\hline Contracorriente & Casi 50000 \\
\hline El elefante desaparecido & 47675 \\
\hline
\end{tabular}

Fuente: Encinta.utero.pe. Elaboración propia (2019) (datos tomados de http://encinta.utero.pe/2015/12/26/todo-lo-que-necesitas-saber-sobre-la-taquilla-delcine-peruano-en-el-2015/)

Estos serían los públicos que segmentan este mercado: 
a) Público cinéfilo: es un público entusiasta que se caracteriza por ser exigente en cuanto a la calidad en el tratamiento y la puesta en escena de una película, que disfruta y analiza con ojo crítico. No solo busca pasar un buen rato, también busca satisfacer sus expectativas por encontrar lo novedoso y distinto. Consume películas que se exhiben en festivales especializados, centros culturales y microcines. También consumen contenido de plataformas de streaming como Netflix, Mubi y Criterion Collection para dar algunos ejemplos. Leen blogs y prensa especializada.

b) Público especializado: este es un público extremadamente pequeño. Tenemos periodistas, bloggers, críticos de cine, seleccionadores de películas para festivales, etc. Consumen cine prioritariamente con un afán crítico y de exploración a través de festivales internacionales y nacionales.

c) Público universitario: Público joven que recientemente se ha interesado por el cine nacional, apoyando propuestas como Wiñaypacha, por citar un ejemplo. El interés quedó demostrado en su exhibición en el Festival de Lima y durante la 3ra Semana del Cine organizado por la Universidad de Lima. La película llamó el interés de los estudiantes, que iniciaron una campaña por redes sociales que logró la extensión de la película en las salas nacionales y con una interesante afluencia del público. De la misma manera, El Limpiador y Chicama lograron respuestas interesantes del público universitario gracias a conversatorios que después se reflejaron en las salas.

\subsection{Segmento objetivo}

Entre los dos segmentos mencionados en el mercado cinematográfico nacional, existe una masa de espectadores cuyos gustos se deslizan entre ambos, mostrando sus preferencias tanto en el cine comercial como en el cine alternativo dentro de los circuitos de la cartelera nacional.

Los perfiles del público potencial al que irán dirigidos los esfuerzos del proyecto son: 
a) Público que consume frecuentemente cine comercial, pero buscando propuestas diferentes y novedosas: Es un espectador que ve cine comercial, pero que no necesariamente está dentro de sus prioridades, porque le atraen alternativas diferentes; está interesado por campañas de marketing novedosas y guiado por recomendaciones. Este grupo está conformado por el público que busca emociones fuertes y que gusta del cine independiente y de autor. Asisten al cine con regularidad, lo que les permite explorar alternativas diferentes, y son a los que principalmente apunta el proyecto. Sus preferencias se orientan por películas como La Última Tarde (2016), La Última Noticia (2015), La Hora Final (2017), Django: Sangre de tu sangre (2018).

b) Público universitario: La buena respuesta de este público hacia propuestas nacionales diferentes a las comerciales hace que el proyecto lo incluya en el público hacia el cual dirige su propuesta. Además es un público recurrente en las salas de cine, y muestra un notable apoyo y afán por explorar al cine nacional, lo cual se nota en su interacción constante con las diversas plataformas digitales.

Estos segmentos de espectadores son los objetivos del proyecto porque sus preferencias de consumo se ubican en la intersección de los gustos por el cine comercial y por el alternativo, y sus características son importantes para consolidar los parámetros del proyecto.

\subsection{Características del Consumidor}

\subsubsection{Construcción del perfil del consumidor}

En el afán de contar con mayores precisiones en la construcción de las características de consumo de nuestro público objetivo, el proyecto se ha apoyado en la investigación realizada por Manrique, Palomares y Villasante (2018), titulada "Estudio de consumo cinematográfico en estudiantes universitarios de Lima Metropolitana”, en donde elaboran por medio de encuestas y entrevistas a profundidad el perfil de tres tipos de consumidores de cine nacional dentro de su universo de investigación (universitarios con edad promedio de 21 años, dividido en tres grupos según edad: de 16-20 años el 52\%, de 21-25 años el 43\% y de 26-30 años el 5\%, de un total de 384 encuestados). Este universo se elige por ser parte de espectadores dentro de nuestro público objetivo. Además, el proyecto utilizará la data arrojada por la mencionada investigación para 
abstraer las características de nuestro consumidor, y agregando las que se han podido deducir al elaborar los alcances del segmento objetivo de proyecto. A continuación, se presentarán algunos cuadros que muestran los resultados de la mencionada investigación y que ayudarán a vislumbrar un perfil más exacto del consumidor al que va dirigido el proyecto.

Tabla 3.7: Frecuencia de consumo de actividades.

\begin{tabular}{|l|c|c|c|c|c|}
\hline & Diario (\%) & $\begin{array}{c}\text { Algunas veces } \\
\text { a la semana } \\
(\%)\end{array}$ & $\begin{array}{c}\text { Algunas veces } \\
\text { al mes (\%) }\end{array}$ & $\begin{array}{c}\text { Casi nunca } \\
(\%)\end{array}$ & Nunca (\%) \\
\hline $\begin{array}{l}\text { Escuchar } \\
\text { música }\end{array}$ & 82.81 & 13.28 & 3.13 & 0.52 & 0.26 \\
\hline Escuchar radio & 19.01 & 30.99 & 20.57 & 23.44 & 5.99 \\
\hline $\begin{array}{l}\text { Jugar } \\
\text { videojuego }\end{array}$ & 8.07 & 21.35 & 19.53 & 29.43 & 21.61 \\
\hline $\begin{array}{l}\text { Leer libros o } \\
\text { novelas }\end{array}$ & 13.54 & 32.29 & 35.94 & 14.58 & 3.65 \\
\hline $\begin{array}{l}\text { Leer } \\
\text { periódicos/revi } \\
\text { stas }\end{array}$ & 14.58 & 30.21 & 30.21 & 20.31 & 4.69 \\
\hline $\begin{array}{l}\text { Navegar } \\
\text { internet }\end{array}$ & 90.36 & 6.77 & 1.56 & 0.78 & 0.52 \\
\hline Redes sociales & 89.84 & 7.29 & 2.08 & 0.78 & 0.00 \\
\hline $\begin{array}{l}\text { Ver noticias, } \\
\text { deportes, } \\
\text { entretenimient } \\
\text { o en TV }\end{array}$ & 38.54 & 35.42 & 15.10 & 7.29 & 3.65 \\
\hline Ver películas & 20.83 & 45.31 & 30.21 & 3.39 & 0.26 \\
\hline Ver series & 27.08 & 38.02 & 27.08 & 5.21 & 2.60 \\
\hline
\end{tabular}

Fuente: Manrique, Palomares y Villasante (2018)

Nuestro consumidor no toma ir al cine como su mayor prioridad de entretenimiento; por eso se ubica dentro del espacio verde que muestra un porcentaje de 45.31\%. Los espacios marcados de amarillo muestran a los espectadores de este universo con una muy alta actividad en internet y redes sociales que se tomará en cuenta. 
Tabla 3.8: Número de películas vistas al mes

\begin{tabular}{|c|c|c|c|c|c|c|}
\hline $\begin{array}{l}\text { Perfil de } \\
\text { consumidor }\end{array}$ & $\begin{array}{l}\text { Menos de } \\
\text { una vez }\end{array}$ & $\begin{array}{c}\text { De } 1 \text { a } 5 \\
\text { veces }\end{array}$ & De 6 a 10 & $\begin{array}{l}\text { De } 11 \text { a } 20 \\
\text { veces }\end{array}$ & Más de 20 & $\begin{array}{l}\text { Total } \\
\text { general }\end{array}$ \\
\hline $\begin{array}{l}\text { Me } \\
\text { encantan las } \\
\text { películas, } \\
\text { soy un } \\
\text { fanático }\end{array}$ & $2(1 \%)$ & $49(31 \%)$ & $66(42 \%)$ & $30(19 \%)$ & 9 & 156 \\
\hline $\begin{array}{l}\text { Me gustan } \\
\text { mucho } \\
\text { algunas } \\
\text { películas; } \\
\text { sin } \\
\text { embargo, es } \\
\text { un interés } \\
\text { secundario }\end{array}$ & $8(4 \%)$ & $104(57 \%)$ & $52(28 \%)$ & $12(7 \%)$ & 8 & 184 \\
\hline $\begin{array}{l}\text { Veo } \\
\text { películas } \\
\text { porque hay } \\
\text { muchas de } \\
\text { ellas, pero } \\
\text { no estoy } \\
\text { particularme } \\
\text { nte } \\
\text { interesado }\end{array}$ & $12(27 \%)$ & $28(64 \%)$ & $4(9 \%)$ & & & 44 \\
\hline $\begin{array}{l}\text { Total } \\
\text { general }\end{array}$ & 22 & 181 & 122 & 42 & 17 & 384 \\
\hline
\end{tabular}

Fuente: Manrique, Palomares y Villasante (2018)

Se resalta con amarillo los consumidores que no muestran un interés primario en las películas, por ser la cualidad que describe a nuestro espectador, en coincidencia con el hecho de que pueden ir al cine de 1 a 5 veces al mes. También es interesante resaltar el número de personas con diferentes intereses que tienen la misma asistencia por mes, que según el cuadro son 181 del universo de la investigación. 
Tabla 3.9: Frecuencia de consumo por género

\begin{tabular}{|c|c|c|c|c|}
\hline Género & $\begin{array}{c}\text { La mayoría de } \\
\text { veces }\end{array}$ & Algunas veces & Rara vez & Nunca \\
\hline & $\%$ & $\%$ & $\%$ & $\%$ \\
\hline Drama & 30.73 & 46.09 & 19.79 & 3.39 \\
\hline Comedia & 47.40 & 41.93 & 9.11 & 1.56 \\
\hline Animación & 27.86 & 43.49 & 23.96 & 4.69 \\
\hline Documental & 9.64 & 31.51 & 40.89 & 17.97 \\
\hline Acción & 41.15 & 35.42 & 16.15 & 7.29 \\
\hline Aventura & 35.16 & 40.63 & 16.41 & 7.81 \\
\hline Fantasía & 26.04 & 40.63 & 21.61 & 11.72 \\
\hline Suspenso/Thriller & 35.94 & 38.28 & 18.49 & 7.29 \\
\hline Romance & 28.13 & 33.85 & 28.13 & 9.90 \\
\hline Terror & 35.68 & 25.26 & 23.96 & 15.10 \\
\hline Ciencia Ficción & 37.24 & 37.76 & 20.57 & 4.43 \\
\hline Musical & 11.20 & 24.22 & 35.94 & 28.65 \\
\hline Histórica & 11.20 & 28.39 & 40.63 & 19.79 \\
\hline Bélica (guerra) & 14.58 & 32.81 & 29.95 & 22.66 \\
\hline Juveniles & 25.00 & 35.42 & 22.92 & 16.67 \\
\hline
\end{tabular}

Fuente: Manrique, Palomares y Villasante (2018)

Como era de esperarse, se verifica que los géneros que más destacan en las preferencias son la comedia, la acción y, en menor medida pero interesantemente, el drama, entre los consumidores de este universo. Importante señalar los gustos por el thriller y el terror. Estas cifras destacan rasgos de nuestro espectador que gusta del drama, el thriller y la acción; y muestra un número considerable de espectadores que tienden a elegir estos géneros. 
Tabla 3.10: Tipo de película vista en los últimos meses

\begin{tabular}{|l|c|c|c|c|}
\hline & Muchas & Algunas & Pocas & Ninguna \\
\cline { 2 - 5 } & $\%$ & $\%$ & $\%$ & $\%$ \\
\hline $\begin{array}{l}\text { Blockbuster con } \\
\text { (películas con } \\
\text { estrellas de cine, } \\
\text { de asistencia } \\
\text { masiva, gran } \\
\text { presupuesto) }\end{array}$ & 56.25 & 31.51 & 6.77 & 5.47 \\
\hline $\begin{array}{l}\text { Independientes } \\
\text { (bajo presupuesto) }\end{array}$ & 9.64 & 32.55 & 38.28 & 19.53 \\
\hline $\begin{array}{l}\text { Películas } \\
\text { Animadas }\end{array}$ & 20.57 & 41.67 & 26.04 & 11.72 \\
\hline Documentales & 7.29 & 23.96 & 36.72 & 32.03 \\
\hline
\end{tabular}

Fuente: Manrique, Palomares y Villasante (2018)

Las preferencias se inclinan en su gran mayoría por los blockbusters, reafirmando las tendencias del público peruano. Sin embargo, hay un gran porcentaje de espectadores que asisten a ver tanto blockbusters como películas independientes. Se puede apreciar una tendencia más equilibrada entre algunos consumidores, para quienes el cine comercial no necesariamente es la primera elección, y se dan tiempo para ver otras cinematografías tanto en lo internacional como en lo nacional. 
Tabla 3.11: Objetivo de ver películas

\begin{tabular}{|l|c|c|c|c|}
\hline & $\begin{array}{c}\text { La mayoría de } \\
\text { las veces }\end{array}$ & Algunas veces & Rara vez & Nunca \\
\cline { 2 - 5 } & $\%$ & $\%$ & $\%$ & $\%$ \\
\hline $\begin{array}{l}\text { Entretenerme y } \\
\text { divertirme }\end{array}$ & 78.65 & 17.45 & 3.65 & 0.26 \\
\hline $\begin{array}{l}\text { Experimentar } \\
\text { fuertes emociones }\end{array}$ & 23.18 & 44.79 & 24.74 & 7.29 \\
\hline $\begin{array}{l}\text { Descubrir y } \\
\text { aprender sobre } \\
\text { personas y } \\
\text { culturas }\end{array}$ & 27.86 & 38.28 & 26.30 & 7.55 \\
\hline $\begin{array}{l}\text { Pasar tiempo de } \\
\text { calidad } \\
\text { amigos ron } \\
\text { familiares y }\end{array}$ & 50.00 & 35.16 & 11.72 & 3.13 \\
\hline
\end{tabular}

Fuente: Manrique, Palomares y Villasante (2018)

El objetivo principal del consumidor que busca el proyecto es entretenerse y divertirse, como señala el casi $79 \%$ de la investigación entre sus encuestados. Esta cualidad debe estar muy presente en la mayoría de públicos que van al cine pero lo que resulta interesante, y se incluiría en el perfil de espectadores que busca el proyecto, es la tendencia, no muy recurrente, por experimentar emociones fuertes para casi el $45 \%$. Esto demuestra que hay un público que en algunos momentos busca propuestas alternativas a las que hay en el mercado.

Cabe destacar que, en el proyecto, las emociones fuertes que pueden buscar experimentar los espectadores se darán a través del uso, por un lado, de un tratamiento dramático explícito en los momentos donde se desenvuelven las acciones truculentas. Mostrando en primeros planos las acciones tortuosas, acompañadas con derramamiento de sangre que demuestran el sadismo de los personajes: Lázaro, motivado por su deseo de venganza, tortura y asesina a los responsables de su tragedia con el mismo ensañamiento que ellos aplicaron con sus seres queridos y los pobladores de Vilca. Por otro lado, con un estilo visual que muestra métodos de tortura de cierta complejidad, 
inspirados en las acciones y torturas realizadas por Sendero Luminoso contra los que consideraban sus enemigos: La muerte de Amaru por medio de la técnica del torniquete (amarrando el cuello con una soga y ajustandola por atrás con un palo para ahoracar) y el dislocamiento de los hombros de Machaqway por medio del jalado de cuerdas de los brazos hacia atrás.

\subsubsection{Perfil del espectador intermedio}

Las preferencias del espectador que se ubica en el segmento objetivo oscilan, como se ha mencionado, entre las opciones que ofrece el cine comercial y el alternativo; por esa característica se le llamará espectador intermedio. Se trata de un consumidor selectivo, cuyas tendencias para la elección de un filme en específico dentro de la cartelera nacional se mueven según la coyuntura, recomendaciones de amigos, gustos por determinado estilo de películas, géneros, directores, etc. De vérselo como un espectador que coloca al cine dentro de sus principales fuentes de entretenimiento, pero no como la más importante.

No es un espectador exigente, pero suele elegir producciones que considera de calidad; no consume películas dobladas, solo subtituladas y en su idioma original. Prefiere los circuitos de cine que están cerca de donde vive o trabaja, que en su mayoría son multicines que se ubican dentro de los distritos de Miraflores, San Isidro, Surco y San Borja. Se mencionan esos distritos porque en su cartelera las películas están subtituladas y en su idioma original; además pueden contar con algunos títulos con menor tendencia comercial, y no están saturados solo de blockbusters.

Esto se corrobora solo con comparar la cartelera de Cineplanet Alcázar y la de Mall del Sur. Ambas pertenecen a la misma cadena, pero en la primera de ellas solo una película está doblada ( La gran aventura Lego 2) y cuenta con dos títulos que son un público más cinéfilo (La favorita y Un ladrón con estilo); mientras que en el Mall del Sur encontramos que todas las películas están dobladas y se identifica un gusto por las películas de terror y ciencia ficción con características del cine comercial. Es notorio que ambas carteleras van a públicos distintos, diferenciados no solo por su ubicación geográfica, sino también por características de consumo. 
Figura 3.8: Características del consumidor intermedio

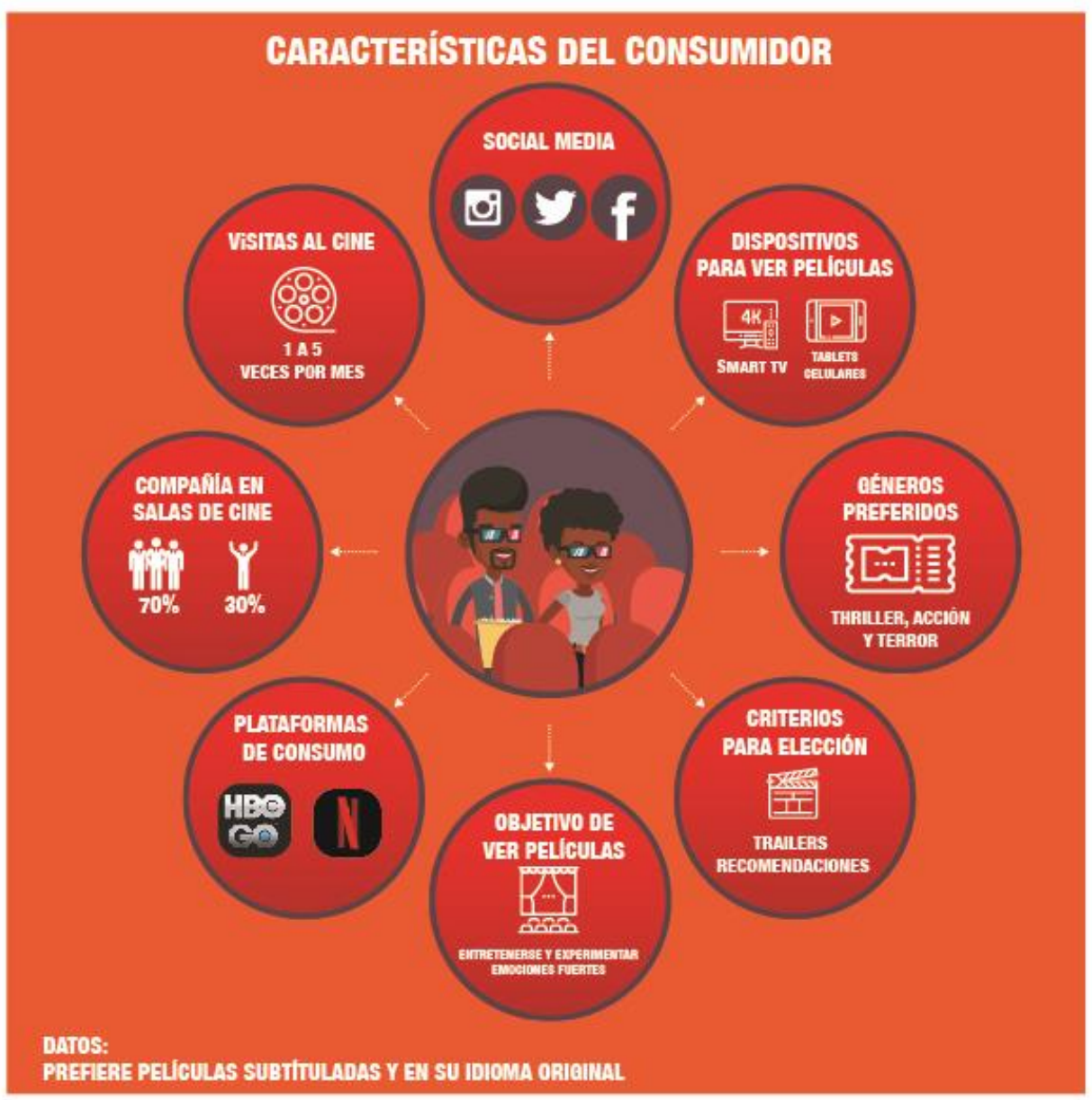

Fuente: Elaboración propia 


\section{CAPÍTULO 4: ANÁLISIS DE LA COMPETENCIA}

\subsection{Competidores principales}

La competencia del proyecto podría ser con cualquier película que comparta el mismo tratamiento de género o género parecido como podría ser el policial, el thriller o el drama; sin importar el lugar de procedencia de la película. Dentro del contexto de la producción nacional con mayores similitudes, lo más actual que encuentro sería Django: Sangre de tu sangre, película dirigida por Aldo Salvini y estrenada en enero del 2018. También está La hora final de Eduardo Mendoza estrenada en el 2017. En lo internacional estaría la película de origen coreano Old boy de Park Chan-Wook, que llegó a nuestros cines en 2006 con el título de Hipnosis mortal.

\subsubsection{Django: Sangre de tu sangre}

La temática del filme de Salvini tiene un parecido con la historia del proyecto, dado que hablan de personajes con un pasado violento que regresan al mundo criminal para lograr recuperar algo que pierden en el pasado. Es un policial que conjuga elementos del cine criminal y el thriller, y crea atmósferas y momentos a través de lo marginal, el lenguaje de la calle y el exceso, elementos que se pensaría estigmatizados por el público por los propios descuidos del cine peruanos de los años 80 s y 90 s. Sin embargo, el filme de Salvini tuvo un buen recibimiento por parte del público y la crítica, y logró un total de 433,047 espectadores, con lo cual demostró que es posible apuntar a una gran taquilla sin tener que recurrir al descuido ni al chiste fácil, como tantas otras películas peruanas, para encontrar el éxito en los últimos años. Ha mostrado un camino para futuras películas de género y temáticas similares que busquen calar en las preferencias de la audiencia nacional. Cabe destacar que Django es la secuela de una película recordada por la gente que en su momento gustó, y que además cuenta con el mismo reparto que popularizó la película original.

El infierno no es un lugar, por otro lado, cuenta con una narrativa barroca, llena circunstancias, momentos y personajes que construyen una historia de venganza que 
puede resultar atractiva al espectador, debido a que ha sido poco tratada en las producciones nacionales, lo cual le daría un caracter de novedad al trasladando la estética visual del cine coreano con el agregado de los matices locales e involucrando las acciones y situaciones propias del barroquismo coreano a los personajes principales que participan en la trama del proyecto: Lázaro vive con remordimientos y frustrado por la impotencia de no poder aliviar sus culpas por las muertes del pasado de las que se siente responsable. Pasando sus días como un muerto en vida, Su situación cambia al encontrarse con uno de los responsables de su desgracia y, a partir de ese momento, moverá cielo y tierra para llevar a cabo su venganza; en donde se dará cuenta que él es vítima de una venganza por parte de su mejor amigo Felipe. La venganza se desarrolla en dos direcciones entre ambos personajes.

Además la historia rememora un pasado vinculado a la época de la violencia en el Perú, y muestra que, aunque estemos en un momento de paz, hay heridas que aún no ha cerrado, con un tratamiento que pocas veces se le ha dado al terrorismo en el cine nacional. Un factor que no puede estar ausente en el proyecto es la presencia de rostros conocidos en la actuación, pero sin apelar a famas televisivas, ya que se busca distanciarse de producciones que buscan aprovecharlas para ser éxitos de taquilla. Esto claramente no es la intención primordial del proyecto.

En cuanto a diferencias en la fotografía, en Django ella es naturalista en exteriores y en interiores la oscuridad contrasta con colores intensos que invaden el ambiente, para exagerar el mundo criminal. La propuesta fotográfica de nuestro proyecto se compone principalmente de colorizaciones azules y verdes, para instalar una atmósfera fría que busca sumergir al espectador en el relato y en la psiquis del personaje, lo cual dista de la intención que se busca en Django en relación con el color. El uso de los planos secuencia, en Django se utiliza el recurso para mostrar el contexto criminal en el que se encuentra su personaje y sumergirlo al espectador en el mismo. En nuestro proyecto este recurso tiene otro objetivo, que es el de seguir una acción, complementándolo con coreografías elaboradas, para ver cómo los personajes pasan obstáculos, y atrapar así al espectador.

Otra diferencia atractiva para el espectador está en el recurso narrativo de varias líneas de tiempo que se encuentran y cobran sentido, para mantenerlo concentrado en la historia a través de más de una línea narrativa. Si bien este recurso narrativo complejiza 
la historia, podría ser atractivo para los espectadores. También el tratamiento sonoro es diferente, ya que se intenta plasmar el mundo criminal en su entorno natural por medio de sus propios sonidos; los reforzamientos musicales se utilizarán para describir el estado psicológico del protagonista en el desenvolvimiento de sus acciones, y para crear atmósferas que generen una mayor sensación de realismo en el espectador. En Django la música se usa como recurso para describir el contexto del barrio, en donde la picardía linda con el peligro.

\subsubsection{La hora final}

Una película de Eduardo Mendoza que se estrenó en septiembre del 2017 y tuvo una buena acogida por parte de los espectadores nacionales, ya que llevó a las salas un total de 224,732 espectadores en las siete semanas que estuvo en cartelera. Tuvo un buen inicio con 70,000 espectadores en su primer fin de semana y más de 100,000 durante la primera semana. La película congregó a muchos espectadores tanto por su temática (se vendía como la película que narraba la captura de Abimael Guzmán), como por el reparto con el que contaba.

Sin embargo, al ver sus números, se nota que tuvo un arranque muy fuerte para luego tener una caída considerable, ya que no mantuvo el éxito de las cifras de la primera semana. El éxito inicial se debió al mérito de una gran campaña mediática, tanto en televisión como en redes sociales, que llamó la atención de varios interesados por ver un policial diferente, inspirado en un evento importante, y esforzado por su estreno el mismo día que se cumplían 25 años de la captura del líder senderista. A pesar de ello, tuvo una caída de público significativa durante las siguientes semanas, debido a que la trama en sí era confusa en muchos momentos, y se perdía la línea narrativa al someter a los personajes a circunstancias inverosímiles que terminaron por confundir al público; además de contar con varias subtramas que no llegaban a despegar. Pero, sobre todo, porque los espectadores no encontraron en la película lo que esperaban ver.

La hora final se vendía como un policial que narraba la captura de Abimael Guzmán por los agentes del GEIN, cuando en la realización lo medular es la historia de amor que se da entre los agentes encubiertos y las dificultades personales de cada uno. 
Esto decepcionó a buena parte del público, que esperaba ver la historia de la captura del líder de Sendero Luminoso como argumento principal.

El proyecto El infierno no es un lugar, al igual que la película de Mendoza, da un peso importante en su argumento a la temática senderista y la violencia histórica, también recurrente en varias producciones nacionales. Pero se diferencia en darle mayor peso al lado ideológico que al histórico, ya que lo utiliza para describir el contexto en que desenvuelve la venganza de Lázaro. Todas las circunstancias, hechos y acciones que suceden se enfocan en la venganza del personaje, manteniendo así la narrativa clara en cuanto a su objetivo. Las líneas de tiempo, en cuanto las idas y vueltas del pasado al presente y viceversa, del proyecto se diferenciarán por medio de maquillaje, vestuario y colorización para que no representen un problema en el seguimiento de la historia y se confunda al público, ya que esos cambios de tiempo cuentan subtramas que cobran sentido en el tiempo presente del filme. Se busca así no repetir errores como los que se presentaron en La hora final en relación al tratamiento de las subtramas.

Finalmente, el proyecto emulará la exitosa campaña que tuvo La hora final en las semanas previas a su estreno, pero buscará diferenciarse dándole al público interesado una historia acorde con el discurso de venta: Se ofrecerá como la historia de un personaje que treinta años después ajusta cuentas con su pasado, por encima del contexto senderista en que se desarrollará en parte. Se presentará un policial con intenciones claras y altos elementos de acción.

\subsubsection{Old boy}

Es un filme coreano del reconocido director Park Chan-Wook, que llegó a las salas del Perú en el 2006 con el título de Hipnosis mortal; en él se narra la historia de Oh Dae-su, que es encerrado e incomunicado sin motivo aparente durante 15 años. Al recobrar su libertad, entra en una desesperada carrera contra el tiempo para llevar a cabo su venganza. La cinta tuvo una muy buena respuesta dentro de la crítica local, pero entre los espectadores obtuvo opiniones muy polarizadas debido a su contenido violento y perturbador, no apto para cualquiera. Además de contar con un título que más bien ahuyentaba el interés de la gente. 
Estas características que ahuyentaron el interés del espectador nacional en Hipnosis Mortal se pueden encontrar en el proyecto. Sin embargo, es evidente que el espectador peruano ha cambiado en sus hábitos de consumo cinematográfico siendo muy diferentes a las del 2006. En la actualidad hay una notable acogida de los espectadores a las producciones nacionales, sobre todo a las de género y ubica la comedia y el terror entre sus favoritas. Esos cambios de consumo del espectador peruano dan una oportunidad al proyecto que se distancia de la película coreana en mención.

Se cita la película por ser un referente importante de nuestro proyecto. Principalmente porque cuenta con elementos narrativos similares, como la venganza redireccionada y sorpresiva, originada por elementos fortuitos de un pasado lejano. Además, es un referente de una narrativa típicamente surcoreana que se caracteriza por tener muchos sucesos y tramas que parecen no relacionarse, para finalmente conectarse con la trama principal, elementos propios de la narrativa barroca del cine surcoreano. Otro elemento que es una fuerte influencia en el proyecto es el tratamiento hiperrealista de la violencia que caracteriza al cine coreano.

Como se ha indicado, el proyecto tiene como gran influencia el tratamiento de la temática vengativa del cine de Corea del Sur, principalmente en el exquisito tratamiento de la venganza del cine de Park Chan-Wook. A pesar de contar con estas marcadas referencias, el proyecto se mostrará como una propuesta novedosa con contenido y referencias locales, que podría ser bien recibido por un público que está abierto a nuevas propuestas, dispuesto a experimentar otro tipo de emociones más allá del mero entretenimiento.

\subsection{Oportunidades}

a) La producción nacional está pasando por su mejor momento en términos de taquilla: Desde el 2013 tanto la producción nacional como la taquilla han mostrado un vertiginoso aumento que, a pesar de sus altas y bajas en algunos años, muestra un panorama esperanzador para el mercado cinematográfico peruano. En el 2016, la asistencia del público a películas nacionales tuvo su pico más alto, pues llegó a pasar los 5.5 millones de espectadores (Cinencuentro 2017). 
Por otro lado, durante el 2018 las películas peruanas estrenadas fueron 59, de las cuales 23 llegaron al circuito comercial (Cinencuentro 2018).

b) Aumento de pantallas de cine a nivel nacional: de 291 pantallas registradas en el 2007, se pasó a contar con 554 para el 2015, lo cual constituye otro claro indicador del crecimiento del mercado cinematográfico en el Perú. Esto significa que las producciones nacionales tienen un espectro más amplio para su exhibición, lo cual implica un mayor tiempo de rotación en el circuito comercial, y un mayor acceso a los espectadores.

c) Aumento en las preferencias por los géneros policial y thriller: en los últimos tres años las películas peruanas que exploraron los géneros del policial y el thriller han tenido una gran aceptación por parte de los espectadores. Solo el año pasado, películas como Caiga quien caiga y Django: sangre de tu sangre estuvieron en la lista de las 10 películas peruanas más vistas del año, y ambas pasaron de los 350 mil espectadores.

d) Mayores incentivos por parte del Estado para la producción nacional: desde el 2011 hasta la actualidad, el Ministerio de Cultura ha ido aumentando el presupuesto para la promoción y contribución con la producción nacional. En el 2018 contribuyó con más de 19 millones de soles distribuidos en 20 categorías para el sector (Ministerio de Cultura 2018).

e) Creación de nuevos festivales en Lima y provincias: El Festival de Lima es el festival más importante actualmente en el Perú y congrega a miles de espectadores interesados en explorar diversas cinematografías. A eso se añade nuevos festivales que se han ido creando en la escena nacional en los últimos años, como la Semana del Cine y el Festival Lima Independiente, que incrementan sus cifras de espectadores cada año, lo cual demuestra un creciente interés del público peruano por producciones diferentes a las que ofrece el circuito comercial. Asimismo, sirven como ventana para muchas producciones nacionales que no logran insertarse en la cartelera de multicines.

\subsection{Amenazas}

a) Acaparamiento de los blockbusters y producciones hollywoodenses en la cartelera nacional: al igual que en otras partes del mundo, las grandes 
producciones hollywoodense recaudan el mayor porcentaje de la taquilla nacional y son por mucho el mayor porcentaje de películas que llegan a la cartelera. Dejan un espacio reducido a las películas nacionales en la elección del espectador, ya que ocupan entre el $65 \%$ al $85 \%$ de la cartelera nacional frente a un $9 \%$ que ocupan las producciones peruanas (Akamine 2017). Con ello, el incremento de pantallas no significa realmente mayor calidad y diversidad en lo que se ofrece.

b) Marcada preferencia del público por la comedia en el cine nacional: en los últimos 5 años la comedia ha sido la preferida del público. Hay que reconocer que son las responsables de reconciliar al espectador con el cine nacional, gracias en gran medida a las producciones de Tondero, que encontraron una "fórmula" exitosa que otros han copiado. Sin embargo, la exclusividad del gusto nacional por estas realizaciones ha generado una gran dependencia de ellas, ya que son las que aportan los números en la taquilla nacional. Por ellos muchos las ven como el único género rentable y se limitan las posibilidades de otros géneros.

c) Hegemonía de las majors en la distribución y exhibición nacional: el dominio de los filmes de los seis grandes estudios estadounidenses ejercen una marcada influencia en la composición de la cartelera nacional. Esto se debe a que cuentan con los taquillazos del año, que, junto a sus otras películas, negocian en paquete con los exhibidores, ejerciendo presión para lograr una posición preferencial frente a otras películas. No solo se empieza con el estreno comercial, sino que también se seleccionan fechas con mucho tiempo de anticipación, para no correr el riesgo de moverse frente a otros estrenos. Así logran acomodar el calendario comercial según sus requerimientos. Con ello dejan en desventaja y ponen obstáculos a las producciones nacionales, que muchas veces tienen que aceptar cualquier fecha para su estreno, para no correr el riesgo de que lo aplacen para mucho tiempo después, y no se perjudiquen las potencialidades de la producción.

d) Ausencia de políticas públicas que promuevan la exhibición de producciones nacionales: el auge del modelo de los multicines en la escena nacional ha ayudado a incrementar la infraestructura de exhibición, pero también ha impuesto un modelo de negocio que se acomoda a las necesidades y presiones de las grandes empresas distribuidoras, y que pone énfasis en los intereses monetarios que los multicines esperan de las películas que llenan sus salas. Este escenario produce que muchas películas nacionales se vean desprotegidas si no gozan de una convocatoria rápida entre la gente, y no duran una semana en la cartelera 
comercial. Esto deja de lado, muchas veces, acuerdos negociados con las distribuidoras y productores, y les quita la oportunidad a las producciones nacionales de competir en igualdad de condiciones. Se carece de políticas públicas que protejan a la cinematografía nacional en este escenario sin igualdad de condiciones y ventaja para las grandes distribuidoras. 


\section{CAPÍTULO 5: MÁRKETING}

\subsection{Estrategia de promoción}

La estrategia que se tomará para la promoción de El infierno no es un lugar parte de los antecedentes dejados por recientes producciones nacionales, que se seleccionaron por contar con características similares a las del proyecto en cuanto a público objetivo al que fueron dirigidas y las estrategias de explotación que eligieron según sus cualidades. Los proyectos referidos son Rosa Chumbe, La hora final y La hija de la laguna; todos ellos ganadores y premiados por el Ministerio de Cultura a través de la Dirección del Audiovisual, la Fonografía y los Nuevos Medios para la gestión y realización de los mismos.

La estrategia tiene como objetivo sorprender en un primer momento, llevando el mundo ficcional del proyecto a la realidad como primer paso, para luego continuar generando contenido adicional durante y después del estreno, para continuar con el enganche del público. Consta de los siguientes elementos:

1. Redes y medios digitales

2. Acciones de márketing de guerrilla

3. Acciones en el mundo real

4. Medios y prensa

5. Elaboración y lanzamiento de piezas promocionales en cuatro fases

\section{Redes y medios digitales (campaña de intriga):}

El público objetivo al que se dirige el proyecto se caracteriza por ser ávidos consumidores de internet y con una constante interacción en las redes sociales a través de distintos dispositivos móviles. Por ello, se diseñará una campaña que genere mucha expectativa por la trama que se desarrolla en la película. Esta campaña está inspirada en campañas como la de The blair witch proyect (1999), que utilizó el recurso de simular los hechos de la ficción como sucesos reales. En el caso de la película se hará lo mismo con los actos del asesino Supay y la obsesiva persecución de Lázaro para llevar a cabo su venganza. Se pondrá en marcha la estrategia por medio de videos y fotografías que 
simulen ser los actos crueles de Supay, y se soltaran en redes a manera de foundfootage, en donde se sugieran los actos del mismo a través de la página web, Facebook, Twitter, Youtube e Instagram. El lanzamiento de cada una de estas plataformas digitales obedecerá a tres etapas diseñadas para los diferentes momentos de la campaña:

- Etapa de expectativa: este es el momento inicial de la campaña que se centrará en generar intriga y expectativa en el público generando el mayor número de posibles espectadores 4 meses antes del estreno, a través de las siguientes plataformas:

$\rightarrow$ Página web: Se diseñará a manera de blog de un usuario anónimo, que sube los videos y fotos, y se generan discusiones con otros usuarios que especulan con la identidad del asesino. Luego del estreno se descubrirá que este usuario anónimo es Lázaro. Esto se hará con la finalidad de aprovechar la secuencia inicial de la película, donde se ve la obsesión que tiene por encontrarlo, para conectar con los espectadores.

$\rightarrow$ Youtube: Se generará un canal en esta plataforma por un usuario anónimo, donde se colgará los videos de los que se habla en el blog falso, donde se muestran los actos de Supay. Todo esto se hará con una estética de foundfootage y sugiriendo una imagen del asesino que nunca se verá con claridad.

$\rightarrow$ Twitter: Se generarán cuentas de usuarios ficticios que están interesados por saber quién es el asesino enmascarado, para generar expectativa entre los usuarios de la red y llevarlos por medio de enlaces a la página web.

- Etapa de crecimiento: este momento se dará un mes antes de la película. Ya se conocerá que la historia de Supay y Lázaro es un universo ficcional, pero se seguirá subiendo material para mantener el interés, explicando la temática de la película a través de entrevistas a los realizadores y actores, escenas polémicas y atractivas de la película (cliffhangers).

$\rightarrow$ Facebook: Fanpage, adonde se subirán los nuevos materiales promocionales de la película.

$\rightarrow$ Instagram: Por ser una plataforma basada en imágenes y videos cortos, se subirán materiales promocionales con la estética foundfootage vinculada a la película, continuando con la intriga por conocer la identidad de Supay. 
$\rightarrow$ Vimeo: Enlace con contraseña de la película completa para público especializado y del medio.

$\rightarrow$ Youtube: Material adicional y complementario de la película

- Etapa de consolidación: este momento se dará durante el tiempo que la película esté cartelera y después que cumpla su ciclo en el circuito comercial.

$\rightarrow$ Facebook: Posteo de noticias sobre la película y lanzamiento de nuevas imágenes complementarias al filme.

$\rightarrow$ Youtube: Nuevo material adicional y complementario de la película junto con escenas del detrás de cámaras.

$\rightarrow$ Instagram: Se subirán imágenes y videos corto donde se darán a conocer pequeños aspectos de la vida de Lázaro.

En el caso de los youtubers del sector, sería importante para la película, dada sus características, contar con su apoyo en la promoción con menciones o concursos donde se regalen entradas y merchandising de la película, además de entrevistas en blogs y páginas web especializados

\section{Acciones de márketing de guerrilla:}

Para complementar el desarrollo digital de la estrategia, se integrará un plan de márketing de acciones de guerrilla, aprovechando la respuesta de la gente a la campaña de intriga, y tratando de que sea coherente con la misma. Un primer paso será la elaboración de carteles con la imagen sugerida de Supay, imitando la estética de fotos tomadas a entidades misteriosas como el yeti, ovnis o el monstruo del lago Ness: afiches de SE BUSCA, y pósters promocionales de la película y colocados en espacios adecuados, por calles y distritos con un alto tránsito de gente.

\section{Conversatorios en universidades:}

Siguiendo experiencias de otras producciones nacionales como $\mathrm{El}$ limpiador y Como en el cine, se organizarán conversatorios en universidades del país para generar un mayor interés en gran parte del público meta al que apunta el proyecto, en donde se repartirán afiches y piezas de merchandising de la película. 


\section{Medios y prensa:}

El plan de márketing apunta principalmente a una campaña digital agresiva que se complemente con acciones de márketing de guerrilla. Sin embargo, no se pueden dejar de lado los principales medios impresos y otros, que se seleccionarán pensando en nuestro público objetivo amplio, pero con gustos exigentes. Asimismo, se contempla la participación en programas de entrevistas de televisión y cable especializados, con publicidad dirigida al público juvenil en sus horarios correspondientes, en noticieros, programas periodísticos y en espectáculos de media noche. Presencia en periódicos y revistas tales como Luces de El Comercio, Somos, Asia Sur, Cosas.

\section{Elaboración y lanzamiento de piezas promocionales en tres fases}

I. Primera fase de preparación: Se elaborarán los materiales como artes gráficos, artículos, clips y videos promocionales previos al rodaje de la película.

a) Contactar a las empresas distribuido y exhibidoras de las regiones donde haya interés en estrenar (Latinoamérica, Norteamérica, Europa y Asia):

1. Elaboración y entrega del Electric Press Kit (EPK) que contendrá los siguientes ítems:

- Sinopsis

- Afiches y pósters

- Videos con entrevistas a los principales miembros del equipo y los actores, hablando sobre la temática de la película y los retos de la puesta en escena.

- Arte de la película

$\rightarrow$ Vestuario, maquillaje, looks.

$\rightarrow$ Tour por las locaciones 
1. Negociación y firma de preacuerdos o contratos con empresas que promuevan la exhibición y distribución de cine latinoamericano, cine independiente, cine de género:

- Negociar los derechos de reproducción y exhibición por el período de un año.

- Negociar los gastos publicitarios y copias necesarias.

\section{b) Promoción e introducción de la película al público nacional}

1. Promoción del material audiovisual de la película: Videos cortos para campaña de intriga, entrevistas, producción de arte, tour de locaciones para redes sociales: Facebook, Twitter, Instagram, Youtube y Vimeo.

2. Promoción del arte gráfico de la película: diseño gráfico general, fotografías, afiche, posters para Instagram.

3. Promoción participativa en blogs, revistas, diarios afines con comunidades interesadas en cine y difusión de la cultura.

4. Actualización perenne de la página web y fanpage de Facebook con los materiales descritos según la etapa que corresponda al momento de la campaña digital.

II. Fase de lanzamiento en el mercado nacional e internacional:

a) Actualización del EPK de la película:

1. Sinopsis

2. Afiches y posters

3. Arte de la película

4. Clips con escenas que generen enganche por el suspense generado (cliffhangers)

5. Teaser y trailers con opción de subtítulos en inglés

6. Composición musical de la película

7. Videos con entrevistas al director, director de fotografía, director de arte. 
8. Videos con entrevistas a los actores donde comenten las particularidades de interpretar a sus personajes, las características del guion, escenas difíciles, etc.

9. Making of.

b) Postulación y presentación de la película a los festivales de cine:

1. Festivales de cine categoría A: Cannes, Venecia, Berlín, Toronto, San Sebastián, Sundance.

2. Otros festivales de interés: BAFICI.

c) Promoción con cuatro meses de anticipación al estreno en salas nacionales, haciendo uso de las estrategias en redes sociales que se enumeran a continuación:

1. Diseñar una campaña de intriga descrita

- Realizar videos que simularán ser grabaciones del mismo asesino.

- Material fotográfico de sus supuestas víctimas.

- Creación de blogs y portales webs que siguen con intriga los actos de Supay donde se generan especulaciones sobre su identidad, origen, inicios, etc.

2. Realización de teasers, trailers y pósters según la segmentación del público:

- Públicos que buscan emociones fuertes

- Públicos que prefieren cine independiente

- Jóvenes universitarios que buscan propuestas diferenciadas

3. Uso intenso de redes sociales con la finalidad de lograr una gran repercusión y captar la mayor cantidad de espectadores posibles a través de una campaña de intriga:

- Virales utilizando Facebook, YouTube e Instagram, divulgando el falso footage, escenas de película (cliffhangers). 
- Generar espacios de debate y discusión en torno a las temáticas que toca la película, a través de la participación de blogs, periódicos y revistas que congreguen a comunidades interesadas en el cine y la difusión de la cultura.

- Lanzamientos de teasers y trailers dirigidos a cada segmento por medio de Facebook, Instagram, Twitter y Youtube.

- Compartir por internet la música compuesta para la película.

- Compartir el arte gráfico de la película por medio de Instagram.

- Exponer el arte de la película con fotografías de los vestuarios y los looks mediante Instagram.

4. Publicidad impresa que nos transporte al contexto de la película:

- Carteles con imágenes sugeridas de Supay

5. Promoción en medios convencionales:

- TV: publicidad dirigida al público juvenil en sus horarios correspondientes, en noticieros, programas periodísticos y shows de media noche.

III. Etapa de consolidación después del estreno para recordar al público que la película está en exhibición:

a) Actualización constante del Facebook y la página webs con entrevistas a los actores y cabezas de las diferentes áreas de la película, material extra y complementarios, making of.

b) Entrevistas en los medios de prensa, blogs y webs especializados, comerciales de televisión y radio. 


\subsection{Plan de ventas}

El infierno no es un lugar es una película que habla sobre la degeneración que produce la venganza en los individuos y toca la temática de la violencia senderista y el mundo criminal. Por esas características y las de su público objetivo, se concibe como una producción de explotación mediana ${ }^{7}$; como señala Tamayo y Hendrickx (2013: 218), es una categoría "p ara películas medianas, de público relativamente amplio y con gustos algo exigentes".

\subsubsection{Distribución}

La película será estrenada comercialmente y se elegirán las salas estratégicamente para que sea vista en 50 pantallas concentradas en los distritos con mayor afluencia del público al que se dirige. Se considerará las características de nuestro público como la interactividad, movilidad, conectividad inmediata por redes para elaborar una estrategia escalonada, que partiría simultáneamente en salas y digital, con la finalidad de intensificar la experiencia del espectador y generar más expectativa antes, durante y después del estreno en salas.

El reto de lanzar la película simultáneamente por estas dos ventanas de distribución requiere discernir entre las que generan ingresos y las que generan enganche y reputación en nuestro público objetivo. A continuación, se detalla el diseño de la propuesta que ha sido pensada teniendo en cuenta las características de un espectador que decide cuándo, dónde y cómo ve un contenido:

\section{A. Distribución en salas comerciales:}

Para la selección de salas a nivel nacional se ha tomado en cuenta aquellas que tienen una alta afluencia de público interesado por propuestas novedosas y experimentar emociones fuertes. Priorizamos salas donde se realizan actividades vinculadas al cine, como festivales y eventos; y las que se encuentran cercanas a universidades y centros de estudio, por las potencialidades que poseen por estar cerca de un público juvenil.

${ }^{7}$ Tamayo, A., \& Hendrickx, N. (2018). Financiamiento, distribución y marketing del cine peruano (2da ed.). Perú: Fondo editorial de la Universidad de Lima 
- Lima: Cineplanet Alcázar, Salaverry, La Molina, Mall del Sur y Norte, Cinemark Jockey Plaza, San Miguel, Open Plaza Angamos y Megaplaza, UVK platino Basadre y Panorama, UVK Caminos del Inca

- Provincias: Cineplanet Arequipa, Cusco, Mall Plaza Trujillo, Cinemark Open Plaza Cajamarca

Con la intención de aumentar las ventas en las salas comerciales, se intentará establecer alianzas con uno o más multicines, para ofrecer paquetes de compra de funciones colectivas para universidades y otros centros de estudio. Estas funciones se programarían en horarios matutinos, que se encuentren dentro de los horarios de estudios de estas instituciones, y se contaría con el tiempo para realizar un intercambio de preguntas y respuestas del público con los realizadores.

\section{B. Exhibición gratuita por internet:}

Por medio de la página web y las redes sociales (como Facebook, YouTube e Instagram), se mostrará contenido adicional de la película que vinculen la ficción con la realidad, a través de videos y fotografías que simulan ser footage encontrado de las acciones del supuesto asesino Supay. Esto se hará para generar el interés del público en los momentos previos al estreno, y se continuarán realizando como material adicional que complemente la historia.

Esta exhibición complementaria del contenido de la película tiene la intención de generar la intriga del público para que hablen y discutan el contenido del filme en su lógica de realidad/ficción en los diversos espacios digitales, para generar recomendaciones y así atraer la mayor cantidad de espectadores posible. Esta estrategia se enmarca en el modelo de negocio freemium, donde se ofrece contenido de forma gratuita que tiene la finalidad de conseguir seguidores a partir de las recomendaciones, para luego ofrecer un servicio pagado con un valor añadido. 
También se ofrecerá el largometraje completo en forma gratuita, mediante un canal de Vimeo, el cual contará con enlace con contraseña, para críticos, periodistas, educadores, programadores de festivales, etc.

\section{Exhibición pagada por internet (3 meses después del estreno comercial):}

Se ofrecerá la película completa acompañada de los materiales extras realizados para la campaña de intriga y el making of en plataforma de pago, como Netflix, Amazon Prime, FilmIn.

\section{Exhibición en Bluray (6 meses después del estreno comercial):}

La venta del disco se lanzará en un empaque digipack que contendrá la película, material de la campaña de intriga, escenas borradas, making of, trailers y teasers, y un pequeño libro ilustrado con fotografías del rodaje, actores caracterizados y escenas de la película, firmado por el director y los actores. El digipack estará disponible solo online en tiendas virtuales, que permitan el pago con tarjeta de crédito y PayPal, con envío a todo el Perú y el mundo, tales como Amazon e EBay. Además, se hará un lanzamiento de un empaque único y de colección que será obsequiado entre la comunidad de nuestras redes.

\section{E. Exhibición de festivales nacionales e internacionales (12 meses antes del estreno comercial):}

Una vez terminadas todas las etapas de producción de la película, se apuntará al circuito de festivales internacionales en un primer momento, y luego se la presentará a los festivales nacionales, con la finalidad de no entorpecer las intenciones que se persiguen con la campaña de intriga que se lanzará los meses previos al estreno comercial.

\section{F. Exhibición en televisión (12 meses después del estreno comercial):}

La película se exhibirá en televisión acompañada de un banner disimulado con frases de la película, con la cual podrá participar por medio de Facebook a sorteos 
por afiches y merchandising de la película. Esta idea fue tomada de la estrategia de distribución de La hija de la laguna, por ser una idea que encaja con las intenciones del proyecto porque incentiva el seguimiento de las redes por parte del público mucho después de pasado el estreno en las salas comerciales.

\subsection{Posicionamiento}

El infierno no es un lugar pretende posicionarse como una película que narra una historia de venganza que surge del mundo de los horrores producidos por la violencia terrorista. Se trata de una película de género policial con elementos de thriller y acción con personalidad autoral. Está orientada al público juvenil que busca propuestas diferentes, que no se deslinden de lo entretenido y estén cargadas de emociones fuertes. Contará con una puesta en escena que busca conmocionar al espectador a través de las motivaciones intensas de sus personaje y en sus acciones representadas con realismo extremo. Es una película visceral, llena de vuelcos narrativos y mucha violencia; que tiene como referentes las cinematografías asiáticas procedentes principalmente de Japón y Corea del Sur de los últimos años. Por eso se presenta como una historia diferente, que explora la temática del terrorismo desde la perspectiva ideológica caracterizada por la decepción, la traición y la lucha por encontrar la redención.

\subsection{Plan de publicidad y medios}

Se propone las siguientes actividades, materiales y parrilla tentativa para el plan de medios.

\section{Actividades necesarias.}

- Envío de notas de prensa prestreno (teaser y trailer)

- Desarrollo de actividades puntuales con los protagonistas y director.

- Rueda de prensa / Press junkets como anuncio de campaña.

- PR con dos meses de anticipación al estreno. 
- Inicio de agenda y entrevistas con los protagonistas (prensa escrita, radio, tv y web)

- Tour de medios con el director

- Sostenimiento del proyecto en medios a través de NDP (durante toda la campaña)

- Coordinación de la conferencia de prensa y avant premier

- Agenda de mantenimiento

\section{Materiales de trabajo}

- Fotos en alta calidad. Foto fija rodaje, making of, afiche

- Material en video para acompañar entrevistas

- Información, sinopsis, cast

- Material gráfico para redes sociales (afiche oficial, banners, etc.)

- Información y contacto de todos los involucrados

\section{Parrilla de medios tentativa}

Figura 5.1: Parrilla de medios

\begin{tabular}{|c|c|c|c|c|}
\hline Diarios & TV & Revistas & Web & Radios \\
\hline El Comercio & Latina & Somos & El Comercio & RPP \\
\hline Perú 21 & América TV & Caretas & Perú 21 & Capital \\
\hline Publimetro & Panamericana TV & Cosas & Publimetro & Radio Nacional \\
\hline La República & TV Perú & Domingo & La Mula & \\
\hline Trome & RTV & Jepública & La República & \\
\hline Exitosa & RPP TV & Ventana & RPP & \\
\hline
\end{tabular}




\begin{tabular}{|l|l|l|c|l|}
\hline & Canal N & & Cinencuentro & \\
\hline & & & Fandango & \\
\hline
\end{tabular}

Fuente: elaboración propia 


\section{CAPÍTULO 6: OPERACIONES}

\subsection{Personal técnico}

\section{Director y guionista}

Carlos Quiroz Figuerola: Es actualmente docente de la Facultad de Comunicación de Universidad de Lima desde hace 9 años, y dirige las jefaturas de prácticas de los cursos de realización audiovisual: Taller de animación digital, Posproducción, Taller de documental, Técnicas audiovisuales y Taller de video. Además, trabaja en el Centro de Creación Audiovisual de la Universidad (CREA), desempeñando distintas funciones relacionadas con el audiovisual, sobre todo a lo relacionado a la dirección y edición de los trabajos que se proponen.

Adicionalmente cuenta con una experiencia de 12 años desempeñándose principalmente en la dirección de proyectos, en su gran mayoría para el sector privado. Es socio y fundador de La Madeja, empresa dedicada a la realización audiovisual desde el 2014, y de una nueva propuesta llamada Recall, empresa dirigida al sector de las nuevas tecnologías y el desarrollo de realidad virtual y aumentada.

En 2018 realizó la producción de su ópera prima La Captura, gracias al premio obtenido por el Concurso Nacional de Proyecto de Cortometrajes y Videos Musicales convocado por la DAFO; actualmente en proceso de postproducción.

\section{Director de fotografía}

Lino Anchi León: También es docente de la Facultad de Comunicación de la Universidad de Lima desde hace 8 años, en los cursos de Expresión Fotográfica y Foto e iluminación. Ha desempañado la dirección de fotografía en dos largometrajes nacionales (Todos somos estrellas y La entidad) y en varios cortometrajes nacionales (El campeón de la muerte, El desayuno, Los pájaros, Aura). También desempeñó el cargo para el cortometraje La captura. 
Se propone su trabajo por su trayectoria y el trabajo realizado junto al director del proyecto durante los últimos años, ya que se ha desarrollado una fuerte conexión y entendimiento en el trabajo que realizan juntos.

\section{Productora}

Macarena Coello Neyra: Es una joven productora que cuenta con una experiencia notable a su corta edad. Se ha desempeñado en el cargo en dos largometrajes: Todos somos marineros (productora de línea) y El corazón de la luna (Coordinadora de producción), película que actualmente está en proceso de postproducción. También para tres cortometrajes (Sheut, Intimidad y Somnotoscopio), todos ellos pertenecientes al mundo de la ficción. Se caracteriza por ser una productora con experiencia en la ficción, que ha explorado en sus producciones los diversos géneros y propuestas cinematográficas con sello de autor. Siempre está motivada para participar en propuestas diferentes y que representen un reto. Actualmente se desenvuelve como productora del Centro de Creación Audiovisual de la Universidad de Lima.

\section{Dirección de Arte}

El proyecto aún no cuenta con alguna propuesta en la dirección de arte, pero se buscarán perfiles acordes con el desarrollo, temática y características del proyecto; se busca profesionales familiarizados con la realización de thrillers, policiales y cine fantástico. Para esa tarea, se proponen los siguientes nombres:

- Hiromi Shimabukuro (Django: sangre de tu sangre)

- Aarón Rojas (El limpiador, Rosa Chumbe, El soñador)

\section{Editora}

Sandra Rodríguez es docente de la Universidad de Lima y postproductora del CREA. Actualmente está editando su primer largometraje: El corazón de la luna de Aldo Salvini, película producida por la Universidad. Gracias a la labor que viene desempeñando en la edición de la película, junto con el trabajo realizado 
con el director del proyecto en CREA, ha desarrollado gran compatibilidad con la visión que el director tiene con el montaje de El infierno no es un lugar.

\subsection{Personal artístico}

Por las características de la producción que es de exploración mediana y el público objetivo al que va dirigida, se ha considerado la posibilidad de rostros conocidos en algunos roles protagónicos o secundarios, pero que no desentonan con el género y la propuesta del filme. Por la etapa en la que se encuentra el proyecto, aún no se han definido el cásting del mismo; sin embargo, se proponen los siguientes actores para los roles protagónicos:

1. Lázaro: Es el personaje principal que ha pasado treinta años esperando el momento para llevar a cabo su venganza. Ha vivido en la clandestinidad gracias a una falsa identidad durante ese tiempo. Se envuelve en la vida criminal con el objetivo de encontrar a Supay, el asesino de Sofía, su novia y hacerlo pagar por eso y los duros años que lo hizo vivir. Es un personaje metódico, atormentado por su pasado y que convive con una ira contenida. Por ello, se buscará a un actor que interprete y exteriorice el mundo interno del personaje.

- Pietro Sibille: Actor peruano de 42 años, conocido por sus interpretaciones de personajes intensos y perturbados en el cine (Días de Santiago, La hora final, La última noticia). 
Figura 6.1: Pietro Sibille. Fotogramas tomados de la película La hora fina

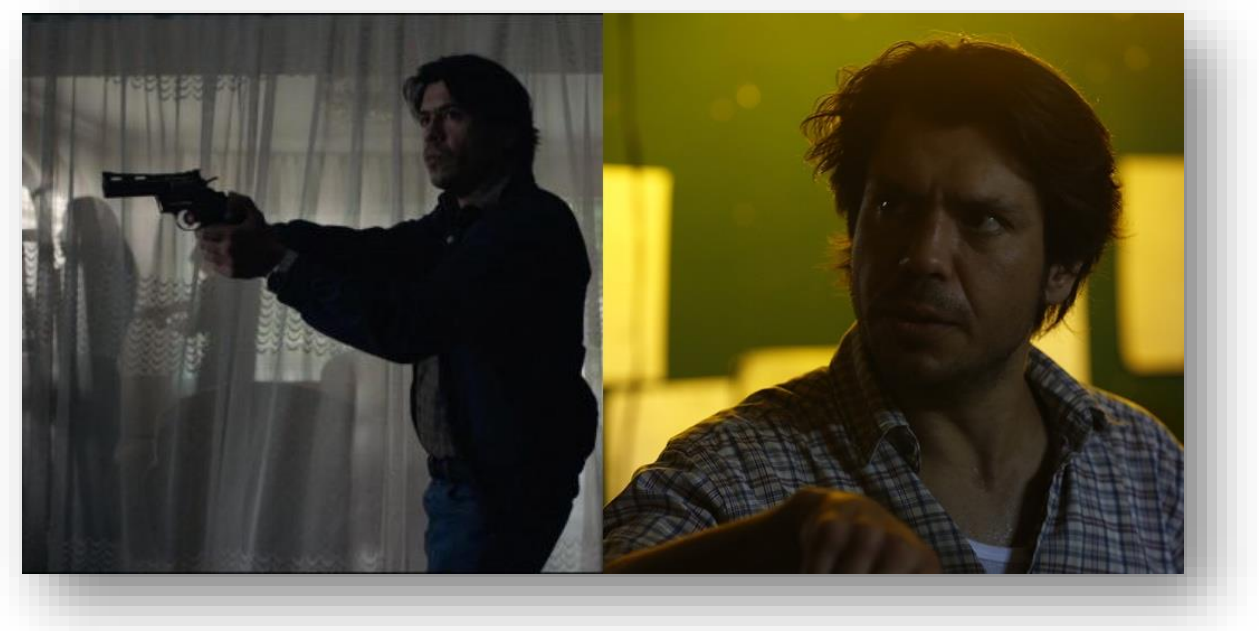

2. Supay: asesino en serie oculto tras una máscara. Buscado por la policía por muchos años sin tener una prueba segura de su identidad, sólo algunos videos y fotografías que circulan en periódicos e internet dan prueba de su existencia. Responsable por la muerte de la novia de Lázaro, y muchas personas de los pequeños pueblos de Ayacucho. Lázaro es uno de los pocos que lo ha visto y sigue con vida, y está obsesionado por encontrarlo para llevar a cabo su venganza y así encontrar la paz de su consciencia. Supay también es Felipe, el único amigo de Lázaro, quien en secreto ha ejecutado la venganza por la muerte de su hermana con Lázaro. Por las características del personaje, el actor que lo interprete debe contar con una marcada trayectoria en roles que exploten la expresión corporal y el trabajo con máscaras, de preferencia. En lo físico debe ser de estatura mediana y tener un rostro que transmita confianza. Las propuestas son:

- Gerardo Zamora: actor peruano de 42 años, conocido por sus roles en la televisión nacional, teatro y cine (Días de Santiago, Flor de retama). 
Figura 6.2: Gerardo Zamora. Fotogramas tomados de la película Súper Cóndor

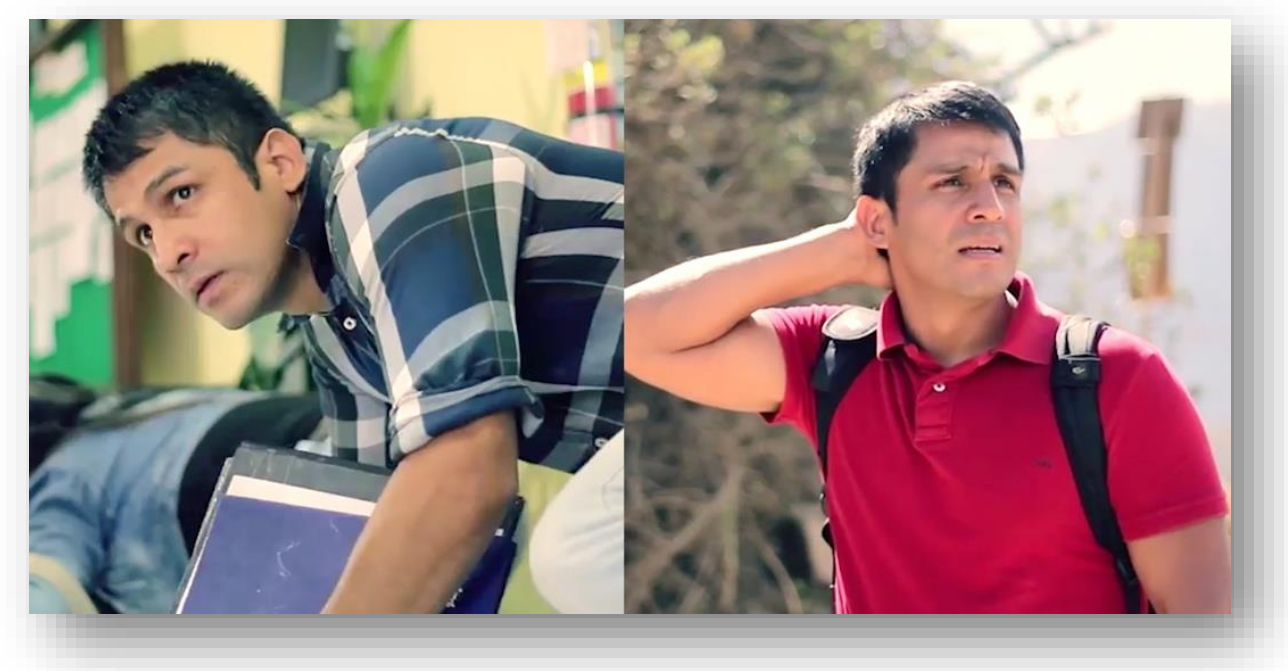

- Amiel Cayo: actor peruano de 50 años; en los últimos años ha interpretado papeles en películas de carácter independiente ( $N N$ : sin identidad, Retablo, The debt).

Figura 6.3: Amiel Cayo. Fotogramas tomados de la película Extirpador de idolatrías

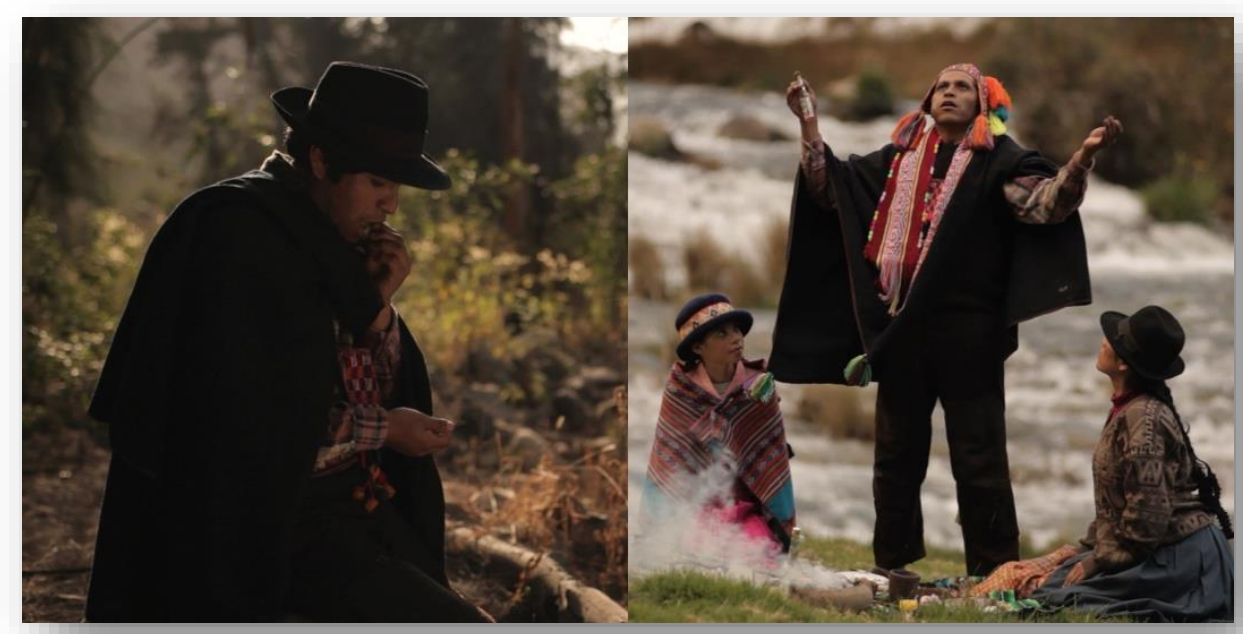




\section{CAPÍTULO 7: FINANZAS}

\subsection{Presupuesto detallado}

Para la realización del presupuesto se ha agregado el 25\% adicional a los servicios de cátering, alquiler de camión de luces, camioneta para cámara, seguridad y los servicios del personal técnico. Ello puesto que se suelen incrementar los costos por estos servicios al tratarse de una grabación en provincias: Ayacucho.

El detalle del presupuesto se suele hacer por etapas (preproducción, producción y post producción) para saber cuanto es la cantidad de dinero necesaria para realizarlas y así buscar el financiamiento para ejecutar el proyecto, que puede ser para que se realice por completo o, dependiendo las dificultades y costos, por etapas. En las películas realizadas hasta el momento, de las que fue posible encontrar la información, no se cuenta con algún antecedente que se haya costeado por mes, debido a que se suele buscar el financiamiento completo para iniciar las diferentes etapas (anexo 3). Generalmente, las etapas de preproducción y producción en un primer momento. A continuación, se hace un listado de películas donde el presupesto se ha realizado costeando la totalidad de las etapas de realización o por departamentos (dirección, arte, fotografía, equipos, etc):

- Viaje a Tumbuctú (2010).

- Wiñaypacha (2013).

- Chicama (2010).

Lo más cercano que se podría hacer para tener una proyección de los gastos de cada mes que dure el proyecto sería dividir el presupuesto total de cada etapa con los meses de duración que se proponen en el cronograma. Según Ricardo Bedoya (2015), las formas en las que se realiza una película se determinan por el modo y el tiempo de cada etapa de producción: preproducción, producción, postproducción y distribución. 
Tabla 7.1: Presupuesto del proyecto

\begin{tabular}{|l|l|}
\hline 1 dólar $=$ & $\mathrm{S} / 3,35$ \\
\hline
\end{tabular}

\begin{tabular}{|c|c|c|c|c|c|c|c|c|}
\hline COD. & Ítem & Unidad & Cantidad & $\begin{array}{c}\text { Costo } \\
\text { Unitario }\end{array}$ & $\begin{array}{l}\text { Costo Total } \\
\text { en Soles }\end{array}$ & $\begin{array}{l}\text { Total item } \\
\text { en Soles }\end{array}$ & $\begin{array}{c}\text { Subtotales } \\
\text { en Soles }\end{array}$ & $\begin{array}{c}\text { Totales } \\
\text { en } \\
\text { dólares }\end{array}$ \\
\hline 1 & GASTOS GENERALES (todas las etapa & & & & & & 55.560 & 16.585 \\
\hline 1.1 & ASPECTOS JURÍDICOS Y FINANCIE & & & & & 11.200 & & 3.343 \\
\hline 1.1 .1 & Asesoria legal y gastos legales & Paquete - & 1 & 3.500 & 3.500 & & & 1.045 \\
\hline 1.1 .2 & Gastos de timbre y notaría & Paquete & 1 & 700 & 700 & & & 209 \\
\hline 1.1 .3 & Gastos de transacciones, transferencias & Paquete - & 1 & 5.000 & 5.000 & & & 1.493 \\
\hline 1.1 .4 & Caja Chica & Seleccio - & 1 & 2.000 & 2.000 & & & 597 \\
\hline 1.2 & \multicolumn{5}{|c|}{ GASTOS ADMINISTRATIVOS Y DE OFICINA } & \multirow[t]{9}{*}{35.000} & & 10.448 \\
\hline 1.2 .1 & Alquiler oficina & Meses & 20 & 1.000 & 20.000 & & & 5.970 \\
\hline 1.2 .2 & Servicios públicos (luz, agua, gas) & Meses & 20 & 150 & 3.000 & & & 896 \\
\hline 1.2 .3 & Teléfonia fija & Meses & 20 & 50 & 1.000 & & & 299 \\
\hline 1.2 .4 & Telefonia movil & Paquete & 1 & 3.500 & 3.500 & & & 1.045 \\
\hline 1.2 .5 & Gastos de conexión a internet & Paquete & 1 & 3.000 & 3.000 & & & 896 \\
\hline 1.2 .6 & Insumos de oficina & Paquete & 1 & 1.500 & 1.500 & & & 448 \\
\hline 1.2 .7 & Alquiler equipos de oficina & Paquete & 1 & 2.500 & 2.500 & & & 746 \\
\hline 1.2 .8 & $\begin{array}{l}\text { Gastos de correo y mensajeria local e } \\
\text { internacional }\end{array}$ & Paquete - & 1 & 500 & 500 & & & 149 \\
\hline 1.3 & \multicolumn{5}{|c|}{ PERSONAL ADMINISTRATIVO Y SERVICIOS } & 9.360 & & 2.794 \\
\hline 1.3 .1 & Secretaria(s) & Paquete & 1 & 5.000 & 5.000 & & & 1.493 \\
\hline 1.3 .2 & Mensajero (s) & Paquete & 1 & 1.000 & 1.000 & & & 299 \\
\hline 1.3 .3 & Contador(es) y asistente contable & Meses - & 12 & 280 & 3.360 & & & 1.003 \\
\hline
\end{tabular}

2 PRE PRODUCCIÓN

2,1 1 PRODUCCIÓN

\begin{tabular}{|r|l|l|l|l|r|}
\hline 2.1 .1 & Productor ejecutivo & Paquete - & 1 & 15.000 & 15.000 \\
\hline 2.1 .2 & Coordinador de producción & Paquete - & 1 & 10.000 & 10.000 \\
\hline 2.1 .3 & Productor de linea & Paquete & 1 & 3.500 & 3.500 \\
\hline 2.1 .4 & Asistente(s) de producción & Paquete - & 4 & 1.000 & 4.000 \\
\hline
\end{tabular}

\begin{tabular}{|r|l|l|l|l|r|}
\hline 2.1 .1 & Productor ejecutivo & Paquete - & 1 & 15.000 & 15.000 \\
\hline 2.1 .2 & Coordinador de producción & Paquete - & 1 & 10.000 & 10.000 \\
\hline 2.1 .3 & Productor de linea & Paquete - & 1 & 3.500 & 3.500 \\
\hline 2.1 .4 & Asistente(s) de producción & Paquete - & 4 & 1.000 & 4.000 \\
\hline
\end{tabular}

\begin{tabular}{|r|l|l|l|l|r|}
\hline 2.1 .1 & Productor ejecutivo & Paquete - & 1 & 15.000 & 15.000 \\
\hline 2.1 .2 & Coordinador de producción & Paquete - & 1 & 10.000 & 10.000 \\
\hline 2.1 .3 & Productor de linea & Paquete - & 1 & 3.500 & 3.500 \\
\hline 2.1 .4 & Asistente(s) de producción & Paquete - & 4 & 1.000 & 4.000 \\
\hline
\end{tabular}

2,2 GUIÓN, DIRECCIÓN Y JEFES DE ÁREA

2.2.1 Guionista

\begin{tabular}{l|l}
2.2 .2 & Director \\
\hline 2.2 .3 & Disector
\end{tabular}

\begin{tabular}{|l|l|}
\hline 2.2 .3 & Director de fotografia \\
\hline
\end{tabular}

2.2.4 Director de arte

2.2 .5 Sonidista

2,3 SCOUTING DE LOCACIONES

\begin{tabular}{|l|l|l|l|l|l|}
\hline 2.3 .1 & Scout de locación & Paquete & 1 & 1.000 & 1.000 \\
\hline 2.3.2 & Productor de locaciones & Paquete & 1 & 9.000 & 9.000 \\
\hline
\end{tabular}

2,4 CASTING

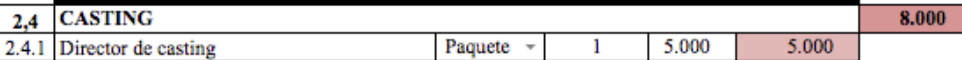

\begin{tabular}{|l|l|l|l|l|l|}
\hline 2.4 .2 & Asistente de casting & Paquete - & 1 & 1.500 & 1.500 \\
\hline 2.4 .3 & Alquiler locaciones para casting & Paquete - & 1 & 1.500 & 1.500 \\
\hline
\end{tabular}

2,5 ENSAYOS

\begin{tabular}{|c|l|l|l|l|l|}
\hline 2,5 & ENSAYOS \\
\hline 2.5 .1 & Pruebas maquillaje, vestuario y escenografia & Paquete - & 1 & 2.000 & 2.000 \\
\hline 2.5 .2 & Al & Pqu
\end{tabular}

\begin{tabular}{|l|l|l|l|l|l|}
\hline 2.5 .2 & Alquiler locaciones para ensayo & Paquete & 1 & 1.000 & 1.000 \\
\hline
\end{tabular}

2,6 PRUEBAS DE CÁMARA

\begin{tabular}{|c|l|l|c|c|c|}
\hline 2,6 & PRUEBAS DE CAMARA \\
\hline 2.6 .1 & Pruebas cámara & Paquete & 1 & 1.000 & 1.000 \\
\hline &
\end{tabular}

27 LOGISTICA

2.7.1 Transporte personas y carga terrestre

\begin{tabular}{l|l}
2.7 .2 & Transporte personas y carga aéreo
\end{tabular}

2.7.4 Alimentación

2.7.5 Alojamiento

2.7.6 Gastos de viaje

\begin{tabular}{|l|l|l|l|}
\hline Paquete - & 1 & 2.000 & 2.000 \\
\hline Paquete & 1 & 7.000 & 7.000 \\
\hline Paquete & 1 & 3.000 & 3.000 \\
\hline Paquete & 1 & 3.000 & 3.000 \\
\hline Paquete & 1 & 2.000 & 2.000 \\
\hline
\end{tabular}




\section{\begin{tabular}{|c|l|}
\hline 3,1 & PERSONAL DIRECCIÓN \\
\hline
\end{tabular}}

3.1.1 Director(es)

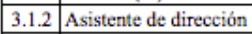

\begin{tabular}{|l|l|}
\hline 3.1 .3 & Otros asistentes de dirección \\
\hline 3.1 .4 & Cos \\
\hline
\end{tabular}

\begin{tabular}{|l|l|}
\hline 3.1 .4 & Continuista (Script) \\
\hline 3.1 .5 & roto Gija \\
\hline
\end{tabular}

\begin{tabular}{|l|l|}
\hline 3.1 .5 & Foto fija \\
\hline 3.1 .6 & Detas de
\end{tabular}

\begin{tabular}{|l|l|}
\hline 3.1 .6 & Detrás de cámaras \\
\hline
\end{tabular}

\begin{tabular}{|l|l|l|r|}
\hline Paquete & 1 & 20.000 & 20.000 \\
\hline Paquete & 1 & 8.000 & 8.000 \\
\hline Paquete & 1 & 3.000 & 3.000 \\
\hline Paquete & 1 & 5.000 & 5.000 \\
\hline Paquete & 1 & 3.000 & 3.000 \\
\hline Paquete & 1 & 2.000 & 2.000 \\
\hline
\end{tabular}

3,2 PERSONAL PRODUCCIÓN

\begin{tabular}{|l|l|l|l|}
\hline & \\
\hline Paquete & 1 & 15.000 & 15.000 \\
\hline
\end{tabular}

\begin{tabular}{|l|l|}
3.2 .1 & Productor $\mathrm{Ejecutivo}$ \\
\hline 3.2 .2 & Coordinador de producción \\
\hline
\end{tabular}

\begin{tabular}{|l|l|}
3.2 .2 & Coordinador de ps. \\
\hline 3.2 .3 & Productor de línea \\
\hline 3.2 .4 & As
\end{tabular}

\begin{tabular}{|l|l|}
\hline 3.2 .4 & Asistente(s) de producción \\
\hline
\end{tabular}

\begin{tabular}{|l|l|l|r|}
\hline Paquete & 1 & 15.000 & 15.000 \\
\hline Paquete & 1 & 7.000 & 7.000 \\
\hline Paquete & 1 & 5.000 & 5.000 \\
\hline
\end{tabular}

\begin{tabular}{l|l}
3,3 & ELENCO \\
\hline
\end{tabular} \begin{tabular}{|l|l|l|l|}
\hline Paquete & 5 & 1.000 & 5.000 \\
\hline
\end{tabular}

\begin{tabular}{|l|l}
3,3 & ELENCO \\
\hline $3,3,1$ & PREL \\
\hline
\end{tabular}

\begin{tabular}{|l|l|}
\hline 3.3 .2 & Secundarios \\
\hline 3.3 .3 & Fin \\
\hline
\end{tabular}

\begin{tabular}{|l|l}
\hline 3.3 .3 & Figurantes \\
\hline 3.3 .4 & Extras \\
\hline
\end{tabular}

\begin{tabular}{|l|l|}
\hline 3.3 .4 & Extras \\
\hline 3.3 .5 & Dobls \\
\hline
\end{tabular}

\begin{tabular}{l|l}
3.3 .4 & Dobles \\
\hline
\end{tabular}

\begin{tabular}{|c|c|c|c|}
\hline Seleccio & 0 & - & 35.000 \\
\hline Seleccio & 0 & - & 30.000 \\
\hline Seleccio & 0 & - & 10.000 \\
\hline Seleccio & 0 & - & 6.000 \\
\hline Dias & 3 & 400 & 1.200 \\
\hline
\end{tabular}

3,4 PERSONAL DEPARTAMENTO DE FOTOGRAFIA

3.4.1 Director de fotografia

3.4.2 Operador de cámara

\begin{tabular}{|l|l|}
\hline 3.4 .3 & Asistente de cámara I (foquista) \\
\hline
\end{tabular}

\begin{tabular}{|l|l}
\hline 3.4 .4 & Asistente de cámara II \\
\hline 3.45 &
\end{tabular}

3.4.5 Técrico de imagen digital (DIT)

3.4.6 Luminotécrico (Gaffer)

\begin{tabular}{|l|l|}
\hline 3.4 .7 & Asistente de luces I \\
\hline 3.49 & Oros asis
\end{tabular}

\begin{tabular}{|l|l}
3.4 .9 & Otros asistentes de luces \\
\hline 3.4 .0 & Maquisis
\end{tabular}

3.4.10 Maquinista

3.4.11 Electricista

\begin{tabular}{|l|l|}
\hline 3.4 .11 & Electricista \\
\hline 3.4 .12 & Operador Steady Cam \\
\hline
\end{tabular}

\begin{tabular}{|l|c|c|r|}
\hline Paquete - & 1 & 20.000 & 20.000 \\
\hline Seleccio & 0 & - & 7.000 \\
\hline Seleccio & 0 & - & 5.000 \\
\hline Seleccio & 0 & - & 3.500 \\
\hline Paquete & 1 & 5.000 & 5.000 \\
\hline Paquete & 1 & 9.000 & 9.000 \\
\hline Paquete & 3 & 5.000 & 15.000 \\
\hline Paquete & 1 & 2.000 & 2.000 \\
\hline Seleccio & 0 & - & 1.600 \\
\hline Seleccio & 0 & - & 2.800 \\
\hline Paquete & 1 & 6.000 & 6.000 \\
\hline
\end{tabular}

\begin{tabular}{|l|l}
3,4 & PERSONAL DEPARTAMENTO DE FOTOGRAFIA
\end{tabular}

\begin{tabular}{|c|l|}
\hline 3.4 .1 & Director de fotografia \\
\hline 3.42 & Opcrator \\
\hline
\end{tabular}

3.4.2 Operador de cámara

\begin{tabular}{lll}
3.4 .3 & Asistente de cámara I (foquista) \\
\hline 3.4 .4 & Assts
\end{tabular}

3.4.4 Asistente de cámara II

\begin{tabular}{|l|l|}
3.4 .4 & Asistente de cánara il \\
\hline 3.4 .6 & Téro de imagen digital (DIT) \\
\hline
\end{tabular}

3.4.6 Luminotécrico (Gaffer)

3.4.7 Asistente de luces I

3.4.9 Otros asistentes de luces

\begin{tabular}{|l|l|}
3.4 .10 & Maquinista \\
\hline 3.4 .1 &
\end{tabular}

3.4.11 Electricista

3.4.12 Operador Steady Cam

Paquete

76.900

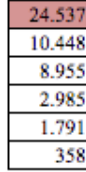

\begin{tabular}{|c|l}
\hline 3,5 & PERSONAL DEPARTAMENTO DE ARTE \\
\hline 3,5 & Di
\end{tabular}

\begin{tabular}{|l|c|c|c|}
\hline Seleccio & 0 & - & 7.000 \\
\hline
\end{tabular}

\begin{tabular}{|l|l|l|l|}
\hline Seleccio - & 0 & - & 5.000 \\
\hline
\end{tabular}

\begin{tabular}{|l|l|l|l|}
\hline Seleccio & 0 & - & 3.500 \\
\hline
\end{tabular}

Paquete

\begin{tabular}{|l|l|l|l|}
\hline Paquete - & 1 & 9.000 & 9.000 \\
\hline
\end{tabular}

\begin{tabular}{|l|r|r|r|}
\hline Paquete - & 3 & 5.000 & 15.000 \\
\hline
\end{tabular}

Paque

\begin{tabular}{|l|c|c|c|}
\hline Paquete & 1 & 2.000 & 2.000 \\
\hline Seleccio & 0 & - & 1.600 \\
\hline Seleccio & 0 & - & 2.800 \\
\hline Paquete & 1 & 6.000 & 6.000 \\
\hline
\end{tabular}

3.5.1 Director de arte

3.5.2 Asistente de arte I

3.5.3 Otros asistentes de arte

\begin{tabular}{|l|l|}
\hline 3.5 .4 & Productor de arte \\
\hline 3.5 .5 & \\
\hline
\end{tabular}

3.5.5 Efectista

3.5.6 Escenógrafo por 5 escenas

3.5.7 Equipo de elaboración de escenografias

\begin{tabular}{|l|l|}
\hline 3.5 .8 & Ambientador \\
\hline 3.5 .0 & Uil ro \\
\hline
\end{tabular}

\begin{tabular}{|l|l}
3.5 .10 & Utilero \\
\hline 3.5 .1 & Asistente(s) \\
\hline
\end{tabular}

3.5.11 Asistente(s) de utileria

3.5.12 Diseñador de vestuario

3.5 .13 Vestuarista

\begin{tabular}{|l|l}
3.5 .14 & Asistente(s) de vestuario \\
\hline
\end{tabular}

3.5.15 Maquillados

3.5.16 Asistente(s) de maquillaje

3,6 PERSONAL DEPARTAMENTO DE SONIDO
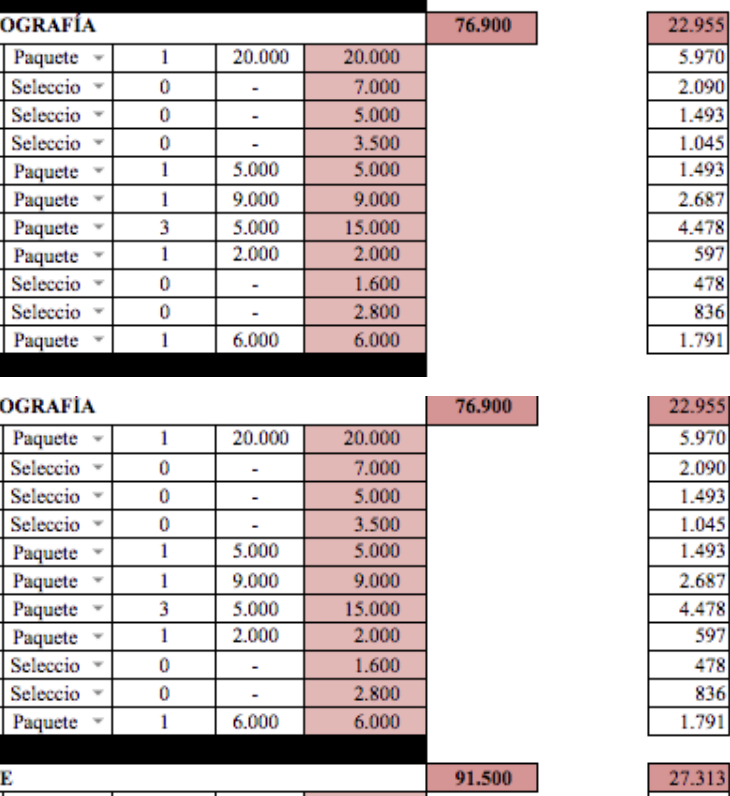

3.6 .1 Sonidista

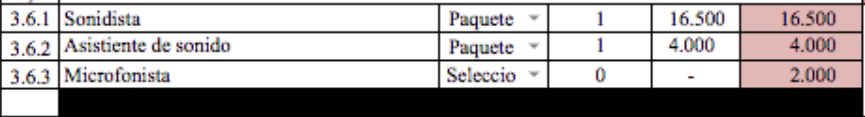

\begin{tabular}{|l|l}
\hline 3,7 & EQUIPO DE RODAJE, ACCESORIOS Y MATERIALES \\
\hline 3.1 & AL
\end{tabular}

\begin{tabular}{|c|c|c|c|}
\hline Paquete & 1 & 16.000 & 16.000 \\
\hline
\end{tabular}

91.500

\begin{tabular}{|l|l|l|l|l|l}
\hline 3.7 .1 & Alquiler Cámara y accesorios $4 \mathrm{~K}$ & Paquete $~$ & 1 & 40.000 & 40.000 \\
\hline
\end{tabular}

\begin{tabular}{|l|l|l|l|l|l|}
\hline 3.7 .2 & Alquiler maleta con 6 lentes más dos ópticas & Paquete $~$ & 1 & 50.000 & 50.000 \\
\hline
\end{tabular}

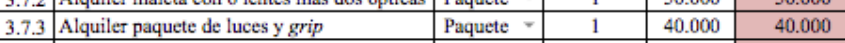

Alquiler otros equipos (grúas, jibs, dollies,

cabezas, camera car, monturas vehículos,

3.7 .4 otros)

3.7 .5 Alquiler generador $100 \mathrm{kw}$

Discos duros u otros medios de

3.7.7 almacenamiento

Compras misceláneas de rodaje, accesorios

3.7 .8 materiales

Paquete

Paquete -

\begin{tabular}{|l|l|l|l|}
\hline Semanas & 4 & 5.200 & 20.800 \\
\hline
\end{tabular}

Sele

nar

2.000 


\begin{tabular}{|c|c|c|c|c|c|c|c|}
\hline \multirow{2}{*}{3,8} & \multicolumn{5}{|c|}{$\begin{array}{l}\text { MATERIALES DE ARTE, ESCENOGRAFIA, UTILERÍA, MAQUILLAJE } \\
\text { Y VESTUARIO }\end{array}$} & 56.000 & \multirow{2}{*}{$\begin{array}{r}16.716 \\
1.493 \\
\end{array}$} \\
\hline & $\begin{array}{l}\text { Efectos especiales en escena: disparos, } \\
\text { explosiones, juegos pirotécnicos, vehículos, } \\
\text { etc. }\end{array}$ & Paquete - & 1 & 5.000 & 5.000 & & \\
\hline 3.8 .3 & Compras y alquileres escenografia & Paquete - & 1 & 20.000 & 20.000 & & 5.970 \\
\hline 3.8 .4 & Compras y alquileres utilería & Paquete $=$ & 1 & 18.000 & 18.000 & & 5.373 \\
\hline 3.8 .5 & Compras y alquileres vestuario & Paquete - & 1 & 9.000 & 9.000 & & 2.687 \\
\hline 3.8 .6 & Compras y alquileres maquillaje & Paquete $*$ & 1 & 4.000 & 4.000 & & 1.194 \\
\hline 3,9 & MATERIALES DE SONIDO & & & & & 100 & 30 \\
\hline 3.9 .2 & Materiales de grabación & Paquete - & 1 & 100 & 100 & & 30 \\
\hline 3,10 & LOCACIONES & & & & & 18.000 & 5.373 \\
\hline 3.10 .1 & Alquiler de locaciones & Paquete - & 1 & 15.000 & 15.000 & & 4.478 \\
\hline 3.10 .2 & Reparación y daños en locaciones & Paquete & 1 & 3.000 & 3.000 & & 896 \\
\hline 3,11 & LOGISTICA & & & & & 138.000 & 41.194 \\
\hline 3.11 .1 & Transporte personas y carga terrestre & Paquete - & 1 & 25.000 & 25.000 & & 7.463 \\
\hline 3.11 .3 & Radios & Paquete $~=$ & 1 & 1.500 & 1.500 & & 448 \\
\hline 3.11 .4 & Enfermería y primeros auxilios & Paquete $=$ & 1 & 3.000 & 3.000 & & 896 \\
\hline 3.11 .5 & Seguridad & Paquete $~$ & 1 & 4.000 & 4.000 & & 1.194 \\
\hline 3.11 .6 & Alimentación & Paquete & 1 & 45.000 & 45.000 & & 13.433 \\
\hline 3.11 .7 & Alojamiento equipo de rodaje y actores & Paquete & 1 & 50.000 & 50.000 & & 14.925 \\
\hline 3.11 .9 & Cafetería y mantenimiento & Paquete - & 1 & 1.500 & 1.500 & & 448 \\
\hline 3.11 .10 & Seguros temporales & Paquete $\sim$ & 1 & 8.000 & 8.000 & & 2.388 \\
\hline
\end{tabular}

\begin{tabular}{|c|c|c|c|c|c|c|c|c|}
\hline 4 & POST PRODUCCIÓN & & & & & & 129.500 & 38.657 \\
\hline 4,1 & EDICIÓN & & & & & 24.500 & & 7.313 \\
\hline 4.1 .1 & Montaje & Paquete - & 1 & 13.000 & 13.000 & & & 3.881 \\
\hline 4.1.2 & Asistente de edición I & Paquete - & 1 & 3.000 & 3.000 & & & 896 \\
\hline 4.1 .3 & Otros asistentes de edición & Paquete & 1 & 2.000 & 2.000 & & & 597 \\
\hline 4.1.4 & Alquiler de equipos de edición & Paquete - & 1 & 6.500 & 6.500 & & & 1.940 \\
\hline 4,2 & LABORATORIO & & & & & 6.000 & & 1.791 \\
\hline 4.2 .1 & Coordinador de postproducción & Paquete - & 1 & 6.000 & 6.000 & & & 1.791 \\
\hline 4,3 & FINALIZACIÓN & & & & & 52.000 & & 15.522 \\
\hline 4.3.1 & Conformación & Paquete - & 1 & 13.500 & 13.500 & & & 4.030 \\
\hline 4.3.5 & Colorización & Paquete $=$ & 1 & 15.000 & 15.000 & & & 4.478 \\
\hline 4.3 .7 & $\begin{array}{l}\text { Subtitulación (subtitulación, subtitulación } \\
\text { DCP, spotting list, traducciones) }\end{array}$ & Paquete - & 1 & 3.500 & 3.500 & & & 1.045 \\
\hline 4.3.9 & Efectos visuales & Paquete - & 1 & 20.000 & 20.000 & & & 5.970 \\
\hline 4,4 & ENTREGA (incluye película y tráiler) & & & & & 13.500 & & 4.030 \\
\hline$\overline{4.4 .2}$ & Copia 0 y posteriores & Paquete - & 1 & 5.000 & 5.000 & & & 1.493 \\
\hline 4.4 .3 & Codificación DCP - DCI & Paquete - & 1 & 3.000 & 3.000 & & & 896 \\
\hline 4.4.4 & Master DCP & Paquete - & 1 & 2.000 & 2.000 & & & 597 \\
\hline 4.4 .5 & Archivo master (HDCamSR u otros) & Seleccio - & 0 & - & 2.000 & & & 597 \\
\hline 4.4 .6 & Formatos varios & Seleccio - & 0 & - & 1.500 & & & 448 \\
\hline 4,5 & SONIDO (incluye película y tráiler) & & & & & 35.500 & & 10.597 \\
\hline 4.5 .1 & Edición de sonido & Paquete - & 1 & 15.000 & 15.000 & & & 4.478 \\
\hline 4.5.2 & $\begin{array}{l}\text { Grabación y edición foley (incluye artista y } \\
\text { sala) }\end{array}$ & Paquete & 1 & 7.000 & 7.000 & & & 2.090 \\
\hline 4.5 .3 & Doblaje & Paquete - & 1 & 3.500 & 3.500 & & & 1.045 \\
\hline 4.5.4 & Mezcla final y codificación & Paquete - & 1 & 10.000 & 10.000 & & & 2.985 \\
\hline 4,6 & MÚSICA & & & & & 49.000 & & 14.627 \\
\hline 4.6.1 & $\begin{array}{l}\text { Derechos música original (composición y } \\
\text { producción temas originales y música }\end{array}$ & Paquete - & 1 & 16.000 & 16.000 & & & 4.776 \\
\hline 4.6.2 & $\begin{array}{l}\text { Estudio de grabación (alquiler, honorarios } \\
\text { personal de estudio, otros) }\end{array}$ & Paquete - & 1 & 13.000 & 13.000 & & & 3.881 \\
\hline 4.6 .3 & Honorarios músicos (intérpretes) & Paquete - & 1 & 20.000 & 20.000 & & & 5.970 \\
\hline 4,7 & TRAILER & r & & & & 4.000 & & 1.194 \\
\hline 4.7 .1 & Elaboración trailer & Paquete & 1 & 4.000 & 4.000 & & & 1.194 \\
\hline 4,8 & LOGÍSTICA & & & & & 14.500 & & 4.328 \\
\hline 4.8.1 & $\begin{array}{l}\text { Transporte personas aéreo nacional o } \\
\text { internacional }\end{array}$ & Paquete - & 1 & 5.000 & 5.000 & & & 1.493 \\
\hline 4.8 .2 & Gastos de envío & Paquete - & 1 & 2.000 & 2.000 & & & 597 \\
\hline 4.8 .3 & Alojamiento nacional o internacional & Paquete - & 1 & 5.500 & 5.500 & & & 1.642 \\
\hline 4.8 .4 & Gastos de viaje & Paquete - & 1 & 2.000 & 2.000 & & & 597 \\
\hline
\end{tabular}




\begin{tabular}{|c|c|c|c|c|c|c|c|}
\hline 4,7 & TRAILER & 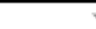 & & & & 4.000 & 1.194 \\
\hline 4.7 .1 & Elaboración trailer & Paquete & 1 & 4.000 & 4.000 & & 1.194 \\
\hline 4,8 & LOGISTICA & & & & & 14.500 & 4.328 \\
\hline 4.8 .1 & $\begin{array}{l}\text { Transporte personas aéreo nacional o } \\
\text { internacional }\end{array}$ & Paquete & 1 & 5.000 & 5.000 & & 1.493 \\
\hline 4.8 .2 & Gastos de envío & Paquete & 1 & 2.000 & 2.000 & & 597 \\
\hline 4.8 .3 & Alojamiento nacional o internacional & Paquete & 1 & 5.500 & 5.500 & & 1.642 \\
\hline 4.8 .4 & Gastos de viaje & Paquete & 1 & 2.000 & 2.000 & & 597 \\
\hline
\end{tabular}

\begin{tabular}{|c|c|c|c|c|c|c|c|c|}
\hline 5 & \multicolumn{6}{|c|}{ PUBLICIDAD, PROMOCION Y DISTRIBUCION } & \multirow{6}{*}{67.000} & \multirow{2}{*}{$\begin{array}{r}20.000 \\
7.761 \\
\end{array}$} \\
\hline $5,1$. & PUBLICIDAD Y PAUTA & & & & & 26.000 & & \\
\hline $5,1.1$ & Publicidad y/o pauta medios impresos & Seleccionar & 0 & - & 5.000 & & & 1.493 \\
\hline $5,1.2$ & Publicidad y/o pauta en internet y medios & Seleccionar & 0 & - & 15.000 & & & 4.478 \\
\hline $5,1.3$ & Diseño y montaje de página web & Seleccionar & 0 & - & 3.000 & & & 896 \\
\hline $5,1.4$ & Impresión material promocional & Seleccionar & 0 & - & 3.000 & & & 896 \\
\hline 5,2 & HONORARIOS & & & & & 23.500 & & 7.015 \\
\hline $5,2.1$ & Diseño y/o producción de campaña & Seleccionar & 0 & - & 5.000 & & & 1.493 \\
\hline $5,2.2$ & Concepto y diseño material impreso & Seleccionar & 0 & - & 3.000 & & & 896 \\
\hline $5,2.3$ & Jefe de prensa & Seleccionar & 0 & - & 2.500 & & & 746 \\
\hline $5,2.4$ & Agentes de prensa & Seleccionar & 0 & - & 1.000 & & & 299 \\
\hline $5,2.5$ & Campaña digital redes sociales & Seleccionar & 0 & - & 12.000 & & & 3.582 \\
\hline & & & & & & & & \\
\hline 5,3 & AVANT PREMIERE & & & & & 5.500 & & 1.642 \\
\hline $5,3.1$ & Conferencia de prensa y relaciones públicas & Seleccionar & 0 & - & 4.000 & & & 1.194 \\
\hline $5,3.2$ & Gastos logística, bebidas y bocaditos & Seleccionar & 0 & - & 1.500 & & & 448 \\
\hline & & & & & & & & \\
\hline 5,4 & DISTRIBUCIÓN & & & & & 4.000 & & 1.194 \\
\hline $5,4.1$ & Inscripciones a festivales y muestras & Seleccionar & 0 & - & 4.000 & & & 1.194 \\
\hline 5.5 & LOGÍSTICA & & & & & 8000 & & 2388 \\
\hline \begin{tabular}{|c|c|c|}
$5,5.1$ \\
\end{tabular} & Transporte personas y carga terrestre & Seleccionar & 0 & - & 2.000 & 年 & & 597 \\
\hline $5,5.2$ & Transporte personas nacional & Seleccionar & 0 & - & 2.000 & & & 597 \\
\hline $5,5.3$ & Alojamiento nacional & Seleccionar & 0 & - & 2.000 & & & 597 \\
\hline $5,5.4$ & Gastos de viaje & Seleccionar & 0 & - & 2.000 & & & 597 \\
\hline 6 & TOTAL & & & & & & 1.090 .060 & 325.391 \\
\hline
\end{tabular}

\subsection{Fuentes de financiamiento}

Respecto del costo del proyecto, para llevarlo a cabo con integridad y con todas sus etapas, el presupuesto asciende a S/. 1023060 soles o \$ 305391 dólares, según la tasa preferencias que se ha colocado (S/. 3.35 x \$1 dólar). Para lograr la realización del proyecto se recurrirá a fondos de ayuda prioritariamente nacionales e internacionales, coproducciones, patrocinios y auspicios como su principal fuente de financiamiento. Existen otros tipos de financianmiento, de los cuales se hará una lista para reconocer las oportunidades que podrían brindarle al proyecto:

1. Concursos Estatales que brindan estímulos no reembolsables: esta sería la principal fuente de financiamiento a la que apuntaría el proyecto, Serían dos principalmente: La Dirección del Audiovisual, la Fonografía y los Nuevo Medios y el Fondo Ibermedia. Estas entidades son las principales fuentes de financiamiento para la realización de proyectos 
cinematográficos en el Perú. Hasta el año 2016, ambas entidades, habían financiado 78 peliculas (EGEDA-UP, 2017).

2. Autofinanciamiento: es la modalidad de financiamiento donde el productor es el que dispone del capital necesario para financiar parte del proyecto o la totalidad del mismo. En el caso de El infierno no es un lugar, se ha considerado un pequeño porcentaje a través de esta modalidad. El origen vendría de los ahorros del realizador que invertiría para ayudar a resolver imprevistos que podrían surgir en las etapas de publicidad y distribución de la película.

3. Prestamos bancarios: El financimiento por medio de préstamos bancarios tendrían que darse por medio de la obtención de un préstamo personal a nombre del productor o realizador. Debido a que las entidades bancarias no suelen prestar dinero para los proyectos con estas características. Esta modalidad de financiamiento -a través del préstamo personal- podría ser una posibilidad para el proyecto, pero en pequeña escala y con la finalidad de cubrir gastos menores para su culminación. Según Hendrickx y Tamayo (2018), los casos en lo que se ha recurrido a esta modalidad de financiamiento son pocos, debido a que en el Perú un filme no puede ser una garantía.

4. Inversionistas: La búsqueda de inversionistas para el proyecto no se descarta, pero sí se tiene una noción clara que es un camino sumamente complicado para conseguir finaciamiento, debido a las características del proyecto: es un filme independiente por no contar con la representación de una casa realizado importante en el Perú, es la ópera prima del realizador y las particularidades del género que contiene grandes cantidades de violencia. Estas caracteríscas se resaltan porque no hay ningún antecedente cinematográfico donde se haya accedido a esta modalidad de financiamiento que cuente con ellas. Las producciones que han logrado financiarse por medio de capital de inversionistas se han particularizado por ser propuestas de productoras importantes como Tondero, por citar un ejemplo. Además, en su mayoría son comedias que tienen una gran acogida por parte de los espectadores peruanos. Un antecedente que mantiene el entusiasmo por la búsqueda de inversionistas para el proyecto, es Cementerio general digida por Dorian Fernández- 
Moris. Este filme de terror logró ser producida en parte por inversiones de empresas de origen amazónico que lograron cubrir gran parte del costo de producción (La Mula, 2013).

5. Coproducciones: son ayudas nacionales o internacionales en las que dos o más empresas se llegan a un acuerdo para unir recursos en pos de la realización de un filme. La búsqueda de coproducciones para el proyecto son las segundas para el proyecto, por porcentaje que se puede obtener para cubrir el presupuesto de la producción. Más adelante se detallan las coproducciones que pueden ser viables para el proyecto.

6. Auspicios y patrocinios: el proyecto apunta a buscar el apoyo de diversas empresas comerciales que podrían estar interesadas en que sus marcas y/o productos figueren en la realización de la película. El monto que se propone el proyecto a recaudar por medio de esta modalidad es un porcentaje pequeño, se podría calcular como máximo un 5\% del costo del proyecto (un aproximado de 50000 soles). De conseguirse este monto, se considerará un extra del presupuesto de la película, que tendrá como finalidad cubrir imprevistos en la realización. Se considera el porcentaje de esta participación debido a las propias características de la película y que están detalladas más a delante.

7. Crownfounding: es una forma interesante de conseguir fuentes de financiamiento y a las cuales el proyecto es totalmente receptivo. Esta modalidad de financiación se centra en apoyar películas que de otra manera no podrían ingresar al mercado cinematográfico que con frecuencia está lleno de producciones con presupuestos medianos o grandes. En otras latitudes como Los Estados Unidos, Canada o Europa es un modelo que cuenta con muchos casos de éxito en el apoyo de cintas independientes para que entren en el mercado cinematográfico, muchos de ellos consiguiendo el apoyo económico para realizar las películas en su totalidad. En el Peru no ha habido esos casos. Sin embargo, hay películas como La última noticia, El limpiador y Rodar contra todo que se valieron del crownfounding para recaudar fondos para ciertas etapas y no para totalidad del proyecto. Para este proyecto se tendrá en cuenta esta modalidad para recaudar fondos para la etapa de postproducción principalmente. 
Los concursos, fondos de ayuda y coproducciones a los que se piensa postular han sido seleccionados porque las características del proyecto se ajustan para su postulación y serían con los que contaría con mayores posibilidades de conseguir sus beneficios, Sin la obtención de los beneficios de los fondos de ayuda no sería muy difícil realizar el proyecto, debiado a que conseguir otras fuentes de financiamiento, A continuación, la tabla donde se muestra nuestro plan de financiamiento.

Tabla 7.2: Plan de financiamiento ${ }^{8}$

\section{Modelo Plan de Financiamiento}

Empresa: LC3J sac

Proyecto: El infierno no es un lugar

\begin{tabular}{|l|l|l|c|}
\hline Origen & Estado & Monto & Porcentaje \\
\hline Recursos propios & Disponible & S/. 20 000 & $2 \%$ \\
\hline $\begin{array}{l}\text { Premios o ayudas } \\
\text { nacionales }\end{array}$ & Por postular & S/. 649 440 & $63 \%$ \\
\hline $\begin{array}{l}\text { Premios o ayudas } \\
\text { extranjeras }\end{array}$ & Por postular & S/. 35 560 & $4 \%$ \\
\hline $\begin{array}{l}\text { Aportes coproducciones } \\
\text { internacionales }\end{array}$ & Por postular & S/. 106746 & $10.5 \%$ \\
\hline $\begin{array}{l}\text { Aportes coproducciones } \\
\text { nacionales }\end{array}$ & Por solicitar & S/. 211 313.50 & $20.5 \%$ \\
\hline Total & & S/. 1 023 060 & $\mathbf{1 0 0 \%}$ \\
\hline
\end{tabular}

\footnotetext{
${ }^{8}$ Modelo de tabla tomado de la Dirección del Audiovisual, la Fonografía y los Nuevos Medios (DAFO).
} 
A continuación, se explica el motivo de la solicitud de los fondos de ayuda y coproducciones según etapas:

1. Primera etapa: Desarrollo y escritura de guion

a. Concurso Nacional de Desarrollo de Desarrollo de Proyecto de Largometraje:

La convocatoria de este concurso ha sido lanzada por la DAFO en los últimos años y cuyo fondo de ayuda que asciende a lo S/. 30000 soles. De ganarse el premio se contará con los fondos para la investigación, el desarrollo y la escritura del guion, para trabajarse en el lapso de un año. Para este concurso se postulará a través de la persona jurídica LC3J S.A.C., con la cual se postuló en el 2018 al Concurso Nacional de Proyectos de Cortometraje, del cual fuimos declarados ganadores de uno de los premios.

b. Solicitud Fondo Ibermedia:

Fondo de ayuda cuyo propósito es la fomentación de estímulos a la coproducción de películas para el cine y la Televisión en los países iberoamericanos. Uno de sus programas es para desarrollos de proyectos y será este al que se postulará en esta etapa, solicitando el monto de US\$ 10,000 para el desarrollo y escritura del guion.

c. Sundance Institute/NHK International Filmmakers Award

Es un premio que se realiza para premiar a cineastas emergentes cuyo talento sirva para el desarrollo de la industria. Al ganador de este premio se le concede la suma de US\$10,000 para el desarrollo del guion, lo cual además incluye la asistencia a reuniones creativas del festival y la ayuda por parte del personal durante el tiempo que dure el proyecto. 
La obtención de estos premios serviría de ayuda para la búsqueda de coproductores y otros fondos de ayuda.

2. Segunda etapa: Preproducción y producción del proyecto

a. Concurso Nacional de Proyectos de Largometraje de Ficción:

El concurso cuenta con un premio máximo de S/. 675,000 soles. Se utilizarían para la gestión de la producción y postproducción del proyecto. La postulación sería con LC3J S.A.C.

b. Solicitud de coproducción con la Universidad de Lima:

La Universidad de Lima se ha caracterizado por brindar apoyos económicos a varias producciones nacionales, a través de patrocinios, en los últimos años. Apoyos que se realizaron por diversos medios: aportes de dinero, préstamos de sus instalaciones, equipos de grabación, equipos de luminaria, prestación de servicios de sus profesionales y apoyo de practicantes. Películas como El bien esquivo, Como en el cine, La vigilia y más, han sido beneficiarias de este tipo de ayuda. Actualmente está asumiendo la producción completa de El corazón de la Luna de Aldo Salvini, a través de su Centro de Creación Audiovisual. Por medio de este centro se solicitará la coproducción con la Universidad, a través de equipos de rodaje, accesorios y materiales, equivalentes a un monto aproximado de S/. 167,800 soles. Anteriormente, ya se ha contado con el apoyo de este tipo por parte de la Universidad en una oportunidad.

c. Solicitud Fondo Ibermedia:

Se postulará al programa de Coproducción para largometrajes y documentales, solicitando el monto de US\$ 50,000.

3. Tercera etapa: Posproducción del proyecto 
a. Solicitud Fondo Hubert Bals del Festival Internacional de Cine de Róterdam:

Este fondo brinda apoyo y da un impulso a cineastas talentosos e innovadores de países con cinematografías en desarrollo, ofreciendo ayudas para el desarrollo de guion y para la posproducción de los proyectos. Se postulará a esta plataforma con la finalidad de contar con el aporte asignado de 30,000 euros para la posproducción.

b. Solicitud de coproducción con la Universidad de Lima:

Se solicitará la ayuda para cubrir gran parte de posproducción, por medio de préstamos de equipos y prestación de servicios profesionales para la edición de la película y el trailer. El monto que cubriría se aproxima en S/. 32,550 soles.

c. Festival de Cine de La Habana:

A través del fondo de ayuda Nuestra América Primera Copia, este festival premia con financiamiento para la posproducción de un proyecto en construcción. El apoyo se da por medio de recursos financieros o en prestación de servicios para que las películas lleguen a ser exhibidas. Se solicitaría un monto que se aproxime a los US\$20,000.

Desde hace algunos años la empresa privada viene invirtiendo en producciones nacionales por medio del product placement, que consiste en mostrar a la marca dentro de la película como mecanismo publicitario; lo óptimo es que se dé con naturalidad dentro de la pantalla. También se da a través de la inserción de la marca en los diferentes materiales promocionales del proyecto ${ }^{9}$, como logo auspiciador. Se buscará el auspicio de marcas que sean afines a la lógica del proyecto. Estas podrían ser:

9 Tamayo, A., \& Hendrickx, N. (2018). Financiamiento, distribución y marketing del cine peruano (2da ed.). Perú: Fondo editorial de la Universidad de Lima 
1. Marcas de motocicletas: por ser el vehículo que se identifica con el protagonista y ser parte importante de la trama.

a. Honda y Yamaha: las marcas idóneas por el posicionamiento que gozan en el Perú por su tiempo en el mercado: imagen de marca del trabajador; resistente, emocionante y divertida a la vez.

2. Bebidas energéticas: por estar vinculadas con las emociones extremas, lo adrenalínico y emocionante.

a. Monster: el estilo de vida que transmite la marca es compatible con las emociones que brinda el proyecto, además de que el gran parte del público objetivo al que va dirigido el proyecto es el público juvenil que sigue a la marca.

Como se puede observar, el proyecto depende de los premios que pueda obtener y en las coproducciónes que pueda conseguir para su ejecución. Sería una prioridad para la realización del proyecto obtener el beneficio del Concurso Nacional de Proyectos de Largometraje y la coproducción con la Universidad de Lima que juntos suman el costo total para la gestión de las etapas de preproducción y producción de la película. Esta dependencia se debe básicamente a que se considera que al buscar fuentes alternativas de financiamiento no se llegaría a obtener un porcentanje del costo importante para ejecutarlo en, por lo menos, dos de las primeras etapas. Debido a las características del proyecto antes descritas y por los escasos antecedentes que se encuentran cuando se revisan casos de películas locales donde la mayor parte del financiamiento haya sido por parte de la inversión privada.

El mercado cinematográfico peruano ha tenido una tendencia ascente en lo que se refiere a la acogida de los espectadores nacionales. Este crecimiento, como se ha detallado anteriormente, se ha dado sobre todo en las cintas de comedia y terror. Aun así, el mercado no se muestra constante y los resultados que tienen la gran mayoría de películas peruanas que llegan a cartelera no siempre son predecibles. Por estos motivos, es díficil asegurar una cantidad mínima de espectadores que tendría que tener para percibir una ganancia. Lo que se podría hacer es un estimado con una cinta nacional con características 
parecidas, y se toma como ejemplo la última película de Aldo Salvini: Django: sangre de tu sangre. Esta película tuvo más de cuatro cientos mil espectadores durante las semanas que estuvo en sala. Con ello, se podría hacer una proyección similar para El iniferno no es un lugar. 


\section{Cronograma}

\begin{tabular}{|c|c|c|c|c|c|c|c|c|c|}
\hline & \multirow[b]{2}{*}{ Actividad } & \multicolumn{8}{|c|}{ Año 1} \\
\hline & & Mes 1 & Mes 2 & Mes 3 & Mes 4 & Mes 5 & Mes 6 & Mes 7 & Mes 8 \\
\hline \multicolumn{10}{|c|}{ Preproducción } \\
\hline 1.1. & Scouting de locaciones & $\mathbf{x}$ & $\mathbf{x}$ & & & & & & \\
\hline 1.2 & Casting de sctores principules y secundurios & & $\mathbf{x}$ & & & & & & \\
\hline 1.3 & Preprouducción de atte: vestuarios y utileriz & & & $\mathbf{x}$ & & & & & \\
\hline 1.4 & Pruebas de cimarza & & $\mathbf{x}$ & & & & & & \\
\hline 1.5 & Pruebas de maquillaje: peinados y looks & & & $\bar{x}$ & & & & & \\
\hline 1.6 & Prueba de maquillaje VFX & & & & $\mathrm{x}$ & & & & \\
\hline 1.7 & Pruebas Visual FX & & & & $\mathbf{x}$ & & & & \\
\hline 1.8 & Tränites permisos de grabación & & & & & & & & \\
\hline 1.9 & Ensayo con actores $y$ pruebes de vessuario & & & & $\mathbf{x}$ & & & & \\
\hline 1.10 & Conatratación de servicios de catering y transpocte & & & & $\mathrm{x}$ & & & & \\
\hline 1.11 & Elaboración güón sénice seripv'storyboard & & & & & & & & \\
\hline \multicolumn{10}{|c|}{ Producción } \\
\hline 2.1 & Rodaje & & & & & $\mathbf{x}$ & & & \\
\hline \multicolumn{10}{|c|}{ Posproducción } \\
\hline 3.1 & Edieión offline & & & & & & $\mathbf{x}$ & $\mathbf{x}$ & \\
\hline 3.2 & Montaje & & & & & & & & $\mathrm{x}$ \\
\hline 3.3 & Colorización & & & & & & & & \\
\hline 3.4 & VFx & & & & & & & & \\
\hline 3.5 & Sonito & & & & & & & & \\
\hline 3.6 & Musicalización & & & & & & & & \\
\hline \multicolumn{10}{|c|}{ Distribución y Marketing } \\
\hline 4.1 & \begin{tabular}{|l|} 
Promocióa y publicidad \\
\end{tabular} & & & & & & & & \\
\hline 4.2 & Avanta premierce y exhibibión & & & & & & & & \\
\hline
\end{tabular}

\begin{tabular}{|c|c|c|c|c|c|c|c|c|c|c|}
\hline & & \multicolumn{9}{|c|}{ Año 1} \\
\hline \multirow{2}{*}{\multicolumn{11}{|c|}{$\frac{1}{\text { Preproduccín }}$}} \\
\hline & & & & & & & & & & \\
\hline 1.1. & Scouting de locaciones & & & & & & & & & \\
\hline 1.2 & Casting de actores principales y secundarios & & & & & & & & & \\
\hline 1.3 & Preproducción de arte: vestuarios y utileria & & & & & & & & & \\
\hline 1.4 & Pruebas de cámara & & & & & & & & & \\
\hline 1.5 & Pruebas de maquillaje: peinados y looks & & & & & & & & & \\
\hline 1.6 & Prueba de maquillaje VFX & & & & & & & & & \\
\hline 1.7 & Pruebas Visual FX & & & & & & & & & \\
\hline 1.8 & Trámites permisos de grabación & & & & & & & & & \\
\hline 1.9 & Ensayo con actores y pruebas de vestuario & & & & & & & & & \\
\hline 1.10 & Contratación de servicios de catering y transporte & & & & & & & & & \\
\hline 1.11 & Elaboración guión ténico scriptstoryboard & & & & & & & & & \\
\hline \multicolumn{11}{|c|}{ Produción } \\
\hline \begin{tabular}{|llll}
2.1 & & & \\
\end{tabular} & Rodaje & & & & & & & & & \\
\hline \multicolumn{11}{|c|}{ Posproducción } \\
\hline 3.1 & Edición offline & & & & & & & & & \\
\hline 3.2 & Montaje & $\mathrm{x}$ & & & & & & & & \\
\hline 3.3 & Colorización & & $\mathrm{x}$ & & & & & & & \\
\hline 3.4 & VFX & & & $\mathrm{x}$ & & & & & & \\
\hline 3.5 & Sonido & $\mathbf{x}$ & & & & & & & & \\
\hline 3.6 & Musicalización & $\mathbf{x}$ & & & & & & & & \\
\hline \multicolumn{11}{|c|}{ Distribución y Marketing } \\
\hline 4.1 & Promoción y publicidad & & & & $\mathrm{x}$ & $x$ & $x$ & $x$ & & \\
\hline 4.2 & Avanta premiere y exhibición & & & & & & & & $\mathrm{x}$ & $x$ \\
\hline
\end{tabular}




\section{Bibliografía}

Escuela de Gestión Pública (Ed). (2017). Impacto Económico del Sector Cinematográfico y Audiovisual y Análisis Costo-Beneficio de la Implementación del Anteproyecto de la Ley de la Cinematografía y el Audiovisual. Lima, Perú: Universidad del Pacífico. Recuperado de: http://dafo.cultura.pe/wpcontent/uploads/2017/09/Estudio-UP-Ley-de-Cine-VF.pdf

Restrepo, F. B., \& Márquez, I. D. (2013). La economía naranja: Una oportunidad infinita. Punto Aparte.

Manrique, G, \& Palomares, F, \& Villasante, J. (2018). Estudio de consumo cinematográfico en estudiantes universitarios de Lima Metropolitana (tesis de pregrado). Pontificia Universidad Católica del Perú, Lima, Perú.

Dirección General de Industrias Culturales y Artes - Ministerio de Cultura. (2016). Dafo - Infoartes. Recuperado de: http://dafo.cultura.pe/wpcontent/uploads/2017/03/Bolet\%C3\%ADn-Infoartes-Sector-audiovisual.pdf

El Comercio. “Año 2018: Estas fueron las películas más vistas por los peruanos [FOTOS].” El Comercio, 29 Dec. 2018, http://elcomercio.pe/luces/cine/cine$\underline{\text { 2018-son-peliculas-vistas-peruanos-noticia-592248 }}$

Akamine, Jaime. “¿Cómo se mueve la industria cinematográfica en el Perú?” El Comercio, 10 Apr. 2017, http://elcomercio.pe/eldominical/actualidad/mueveindustria-cinematografica-peru-413161.

Gestión, R. “Las preferencias del espectador peruano: ¿qué tipo de películas ven?” (2017, June 07). Recuperado de https://gestion.pe/tendencias/preferencias-espectadorperuano-tipo-peliculas-ven-136703 
Chávez, R., Chávez, R., Zavala, S., Zavala, S., Sarmiento, Á, Chunga, F., . . Ugarelli, J. C. (2017, December 31). "Análisis de la taquilla del cine peruano 2017 (parte 1)". Recuperado de https://www.cinencuentro.com/2017/12/30/analisistaquilla-cine-peruano-2017-pt-1/

Chávez, R., Ugarelli, J. C., Wong, A., Sarmiento, Á, Chunga, F., Ugarelli, J. C., . . . Ugarelli, J. C. (2019, February 12). “Análisis de la taquilla del cine peruano del 2018”. Recuperado de https://www.cinencuentro.com/2019/02/07/analisistaquilla-cine-peruano-2018/

Tamayo, A., \& Hendrickx, N. (2018). Financiamiento, distribución y marketing del cine peruano (2da ed.). Perú: Fondo editorial de la Universidad de Lima

Bardales, P. (2013). ¿Es posible creer en una industria de cine en el Perú? La Mula: lamula.pe. Perú. Recuperado de: lamula.pe/2013/04/12/es-posible-creer-en-unaindustria-de-cine-en-el-peru/pacobardales/

Bedoya, R. (2015). Formas y métodos de producción de cine en el Perú. Lima: Fondo Editorial. Universidad de Lima. 


\section{Referencias}

Denegri, C. (productora) \& Calero, J. (director). (2016). La última tarde. Perú: Factoría Sur Producciones / Bhakti Films

Útero. Todo lo que necesitas saber sobre la taquilla del cine peruano en el 2015. (n.d.). Recuperado de: http://encinta.utero.pe/2015/12/26/todo-lo-que-necesitassaber-sobre-la-taquilla-del-cine-peruano-en-el-2015/

Portocarrero, J. (productor) \& Legaspi, A. (2015). La última noticia. Perú: Grupo Chaski

Mendoza, E. (2017). La hora final. Perú: La Soga Producciones

Ciccia, G. (productor) \& Salvini, A. (director). (2018). Django: Sangre de mi sangre. Perú: La soga producciones

Gum, T. (productora) \& Mitchell, M. (director). (2019). La gran aventura Lego 2. EEUU: Warner Bros. / LEGO / Warner Animation Group / RatPac-Dune Entertainment / Vertigo Entertainment / Village Roadshow / Lin Pictures

Lanthimos, Y. (director). (2018). La favorita. EEUU: Coproducción Reino UnidoIrlanda-Estados Unidos; Element Pictures / Scarlet Films / Film4 Productions / Waypoint Entertainment

Lowery, D. (director). (2018). Un ladrón con estilo. EEUU: Dentity Films / Wildwood Enterprises / Endgame Entertainment / Conde Nast Entertainment / Sailor Bear.

Park, C. (director). (2003). Old boy. Corea del Sur: Show East Co. Ltd

Chávez, R., Chávez, R., Chávez, R., Chávez, R., Sarmiento, Á, Chunga, F., . . Ugarelli, J. C. (2017, July 01). Taquilla 2016 (parte 4) - Números reales, ¿crece en verdad el cine peruano? Recuperado de: 
https://www.cinencuentro.com/2017/07/01/taquilla-2016-crece-en-verdad-elcine-peruano/

Chávez, R., Chávez, R., Zavala, S., Zavala, S., Sarmiento, Á, Chunga, F., . . Ugarelli, J. C. (2017, June 19). Taquilla 2016 (parte 1) - Los reyes del cine peruano. Recuperado de: https://www.cinencuentro.com/2017/06/15/taquilla-2016reyes-del-cine-peruano-tondero/

Myrick, D. \& Sanchez, E. (directores). (1999). El proyecto de la bruja de Blair. EEUU: Artisan Entertainment / Haxan Films

Siles, M. (director). (2014). Extirpador de idolatrías. Perú: La Luna Pintad Producciones

Nieto, A. (director). (2015). Súper Cóndor. Perú: Nima Producciones 


\section{Anexos}

Anexo 1: Guión (Primera Versión) 
Anexo 2: Propuesta de Afiche

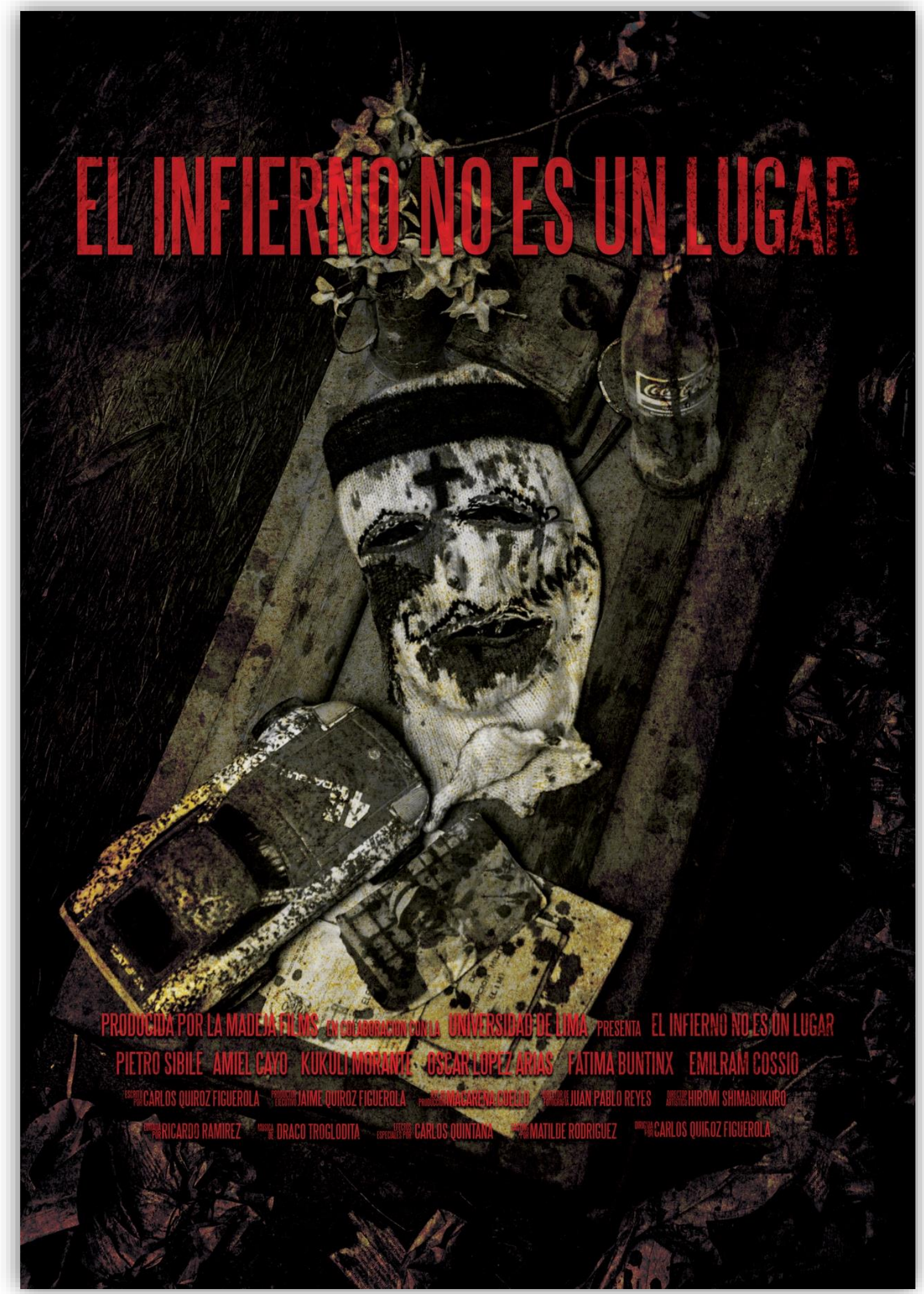




\section{Anexo 3: Modelos de presupuesto}

Viaje a Tumbuctú (2010)

+ PAESUPUESTO VIAE A TOMBUCTÚ - TOMEUKTU FILMS

Anexo A.

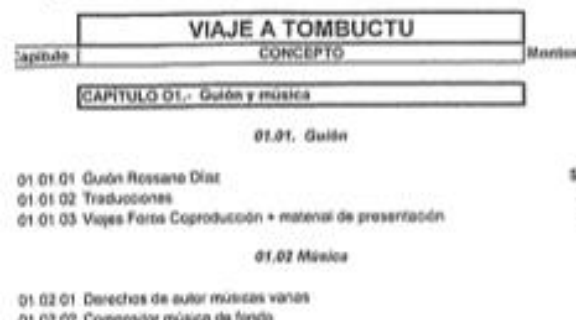

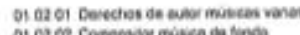

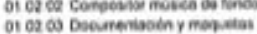

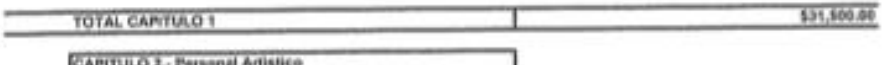

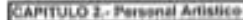

o2.01 Proteganisites

cot ot os Menara

of ot 02 Mna mara

Der

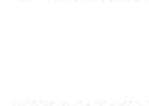

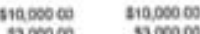

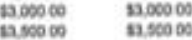

\section{2 az Prineipalos}

020201 Camen

0020202 Poos

120200 Manan

020205 Mana with

$\$ 1000000$

35.00000

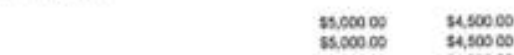

$\$ 1,00000 \quad \$ 1,500000$

$1,00000-31,40000$

32,00000
51,0000

31,00000000

02.03 Secusdainos

azos os cartande.

020302 Carie anevor

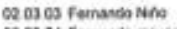

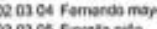

020305 Fonets roper

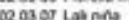

Q2 03 ca Lat mayn

02 0309 Pepe reto

Q2 es 10 Pose eneyou

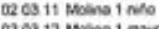

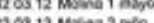

(1)

O2.00 14 Moles 2 mog

$240000 \quad 235000$

400000000000

$500000 \quad 5500$

$500006 \quad 530000$

$545006 \quad 530000$

$\begin{array}{lll}500000 & 354000\end{array}$

$\begin{array}{ll}540000 & \$ 36000 \\ 500000 & \$ 540000\end{array}$

$\begin{array}{ll}500000 & \$ 59000 \\ 500000 & \$ 36050\end{array}$

$500000 \quad 154060$

\$50000000

$\$ 15000 \quad \$ 13500$

62 or 01 Moldatera

020400 Setiotos?

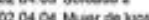

pat os ot Otreve I

2 or ces Ches 1 fiesis

0204 or Euspas

az ces on cholos bus

02 on 03 soldor 1 an

azor 10 Mand so Fordas.

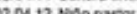

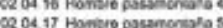

02 as Figureelisa (extras)

$51500 \quad 51500$

02.04 Pequelas partes

sises

$\begin{array}{ll}51500 & 52500 \\ 11500 & 51500\end{array}$

$11500 \quad 51500$
12000

$\begin{array}{ll}12500 & 52500 \\ 57000 & 57000\end{array}$

$\$ 7000 \quad 57000$
$\$ 7000$

$\$ 7000 \quad \$ 5000$

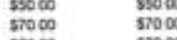

57000

s00 00

35000
35000

35000
55000

56000
55000

55000
$\$ 5000$

$\sin 00$

31500

51500

02 es 02 Tacosis bus

02 co is Tanstats Aarcopione

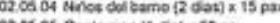

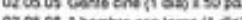

cesol

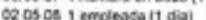

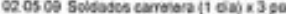

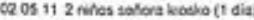

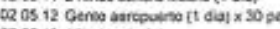

O2 CS 13 Aliader (1) Sial)

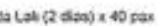

(1) dal $\times 20$ pe

1 sai) $\times 10$ pax

\begin{tabular}{|c|c|}
\hline & \\
\hline $\operatorname{sis} \infty$ & 31500 \\
\hline $5: 500$ & 51500 \\
\hline & 55000 \\
\hline 510000 & $\$ 76000$ \\
\hline s1s 00 & $\$ 1500$ \\
\hline 31500 & S1500 \\
\hline$\$ 1500$ & $\$ 1500$ \\
\hline$\$ 3000$ & 20000 \\
\hline$\$ 50000$ & 5500 \\
\hline 30000 & $395 \infty$ \\
\hline 530000 & 350000 \\
\hline 51500 & MISc0 \\
\hline 580000 & 530000 \\
\hline$\$ s 000$ & 25000 \\
\hline 515000 & 513000 \\
\hline 200000 & $=00000$ \\
\hline
\end{tabular}

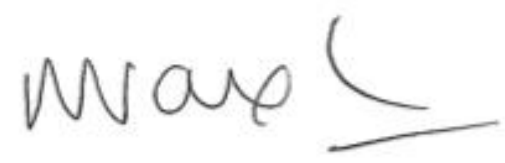




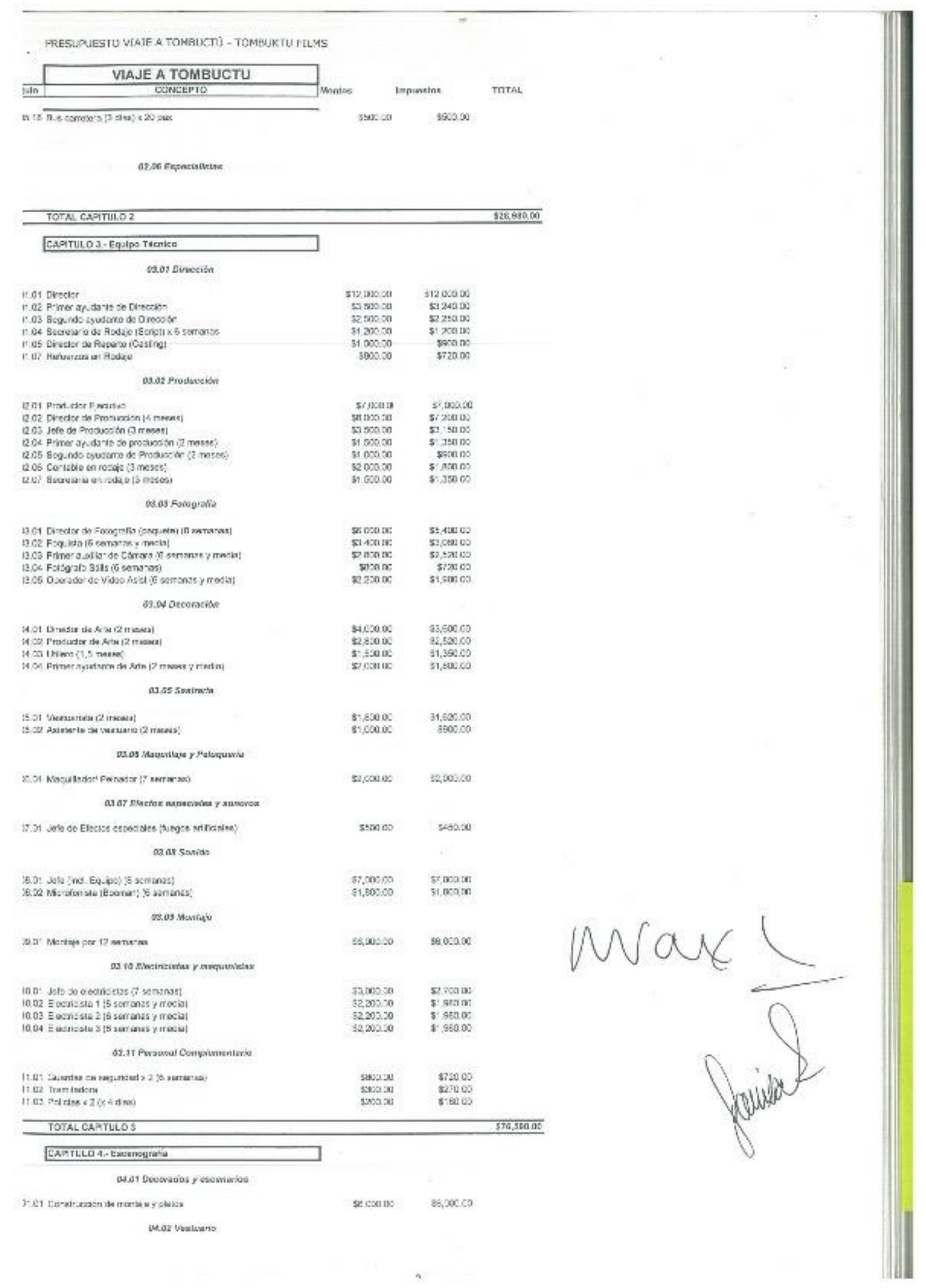



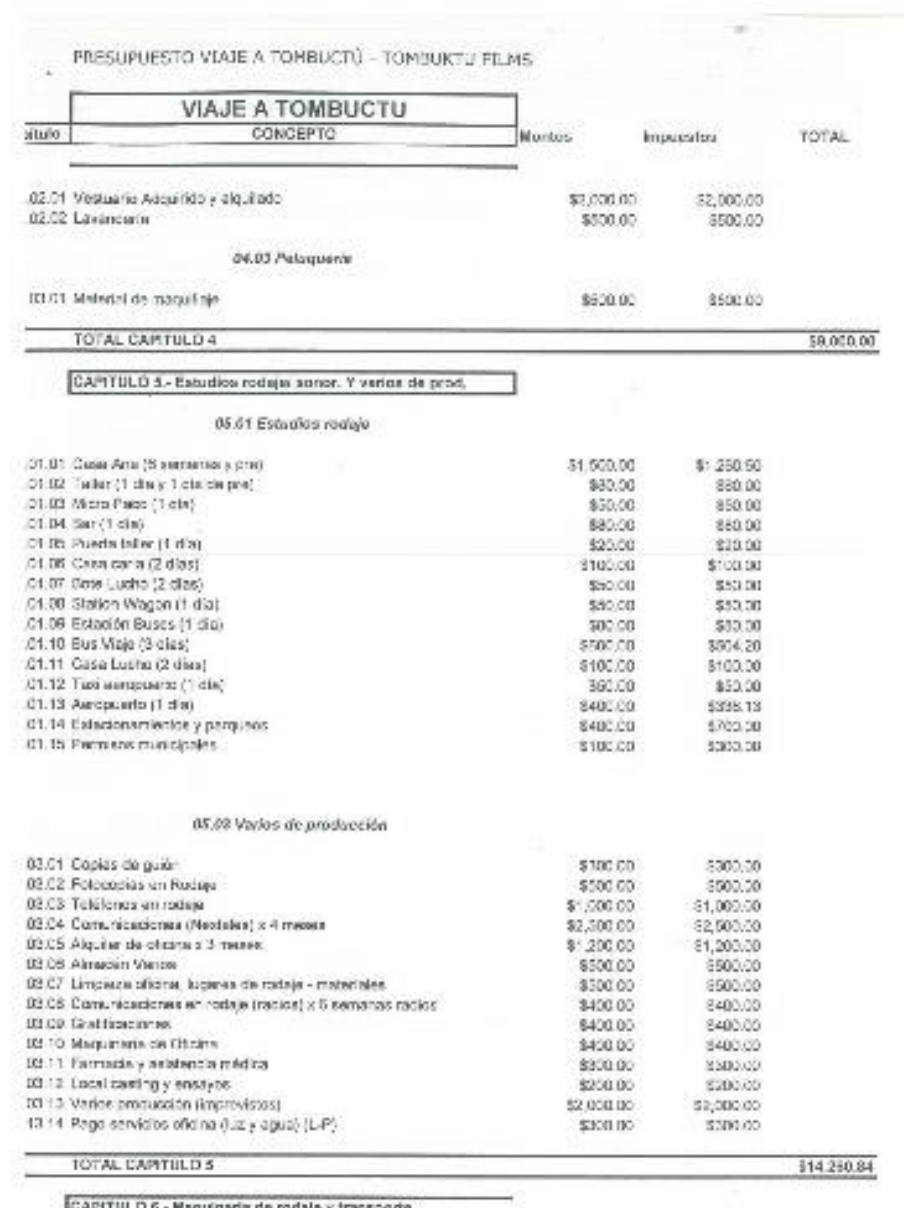

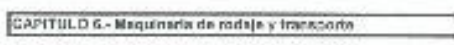

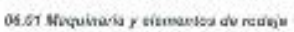

61. C: Cimas arcasis

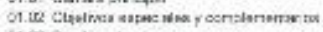

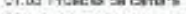

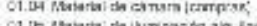

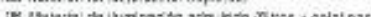

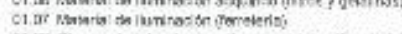

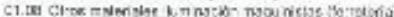

C1: IE Asintoms

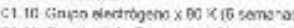

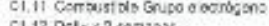

c1.13 grosity Gan

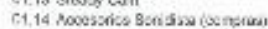

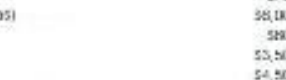

\$18.05axe 330000:

3100000 a1 6000

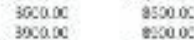

arsocax sisecos

3ecax soceo:

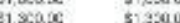

sace sisuo

sisace sisul:

șaili:

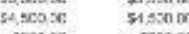

$142 \pm 0.4$

as.or Trumporsta an nothin

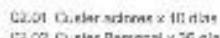

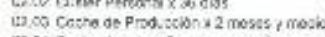

cres cothe de sno 2 masse : rock

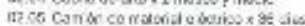

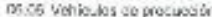

06.0T Basoline

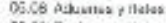

D.CO Toia ne vatem

Fon:

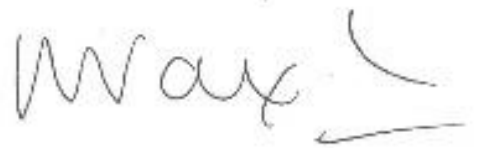

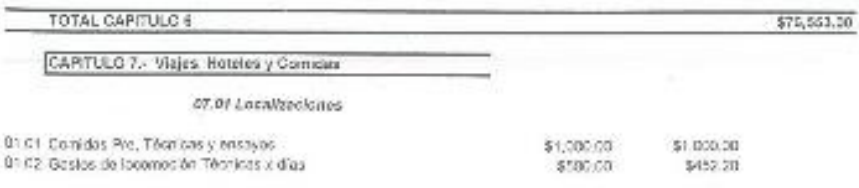

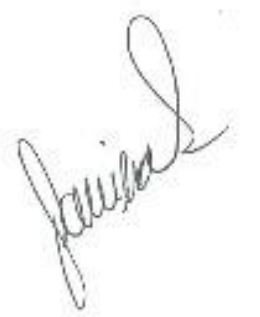

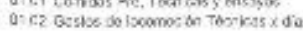




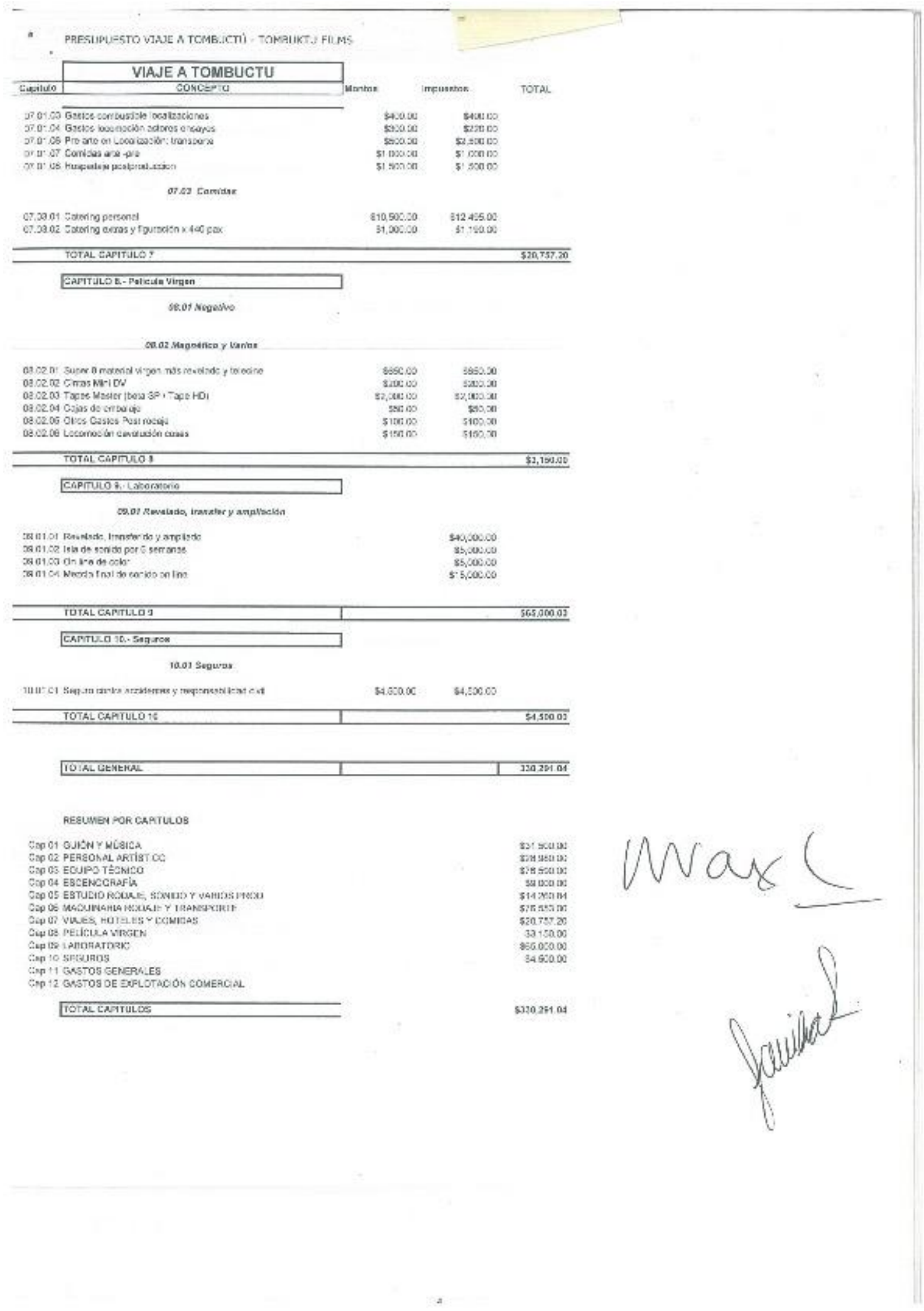


Wiñaypacha (2013)

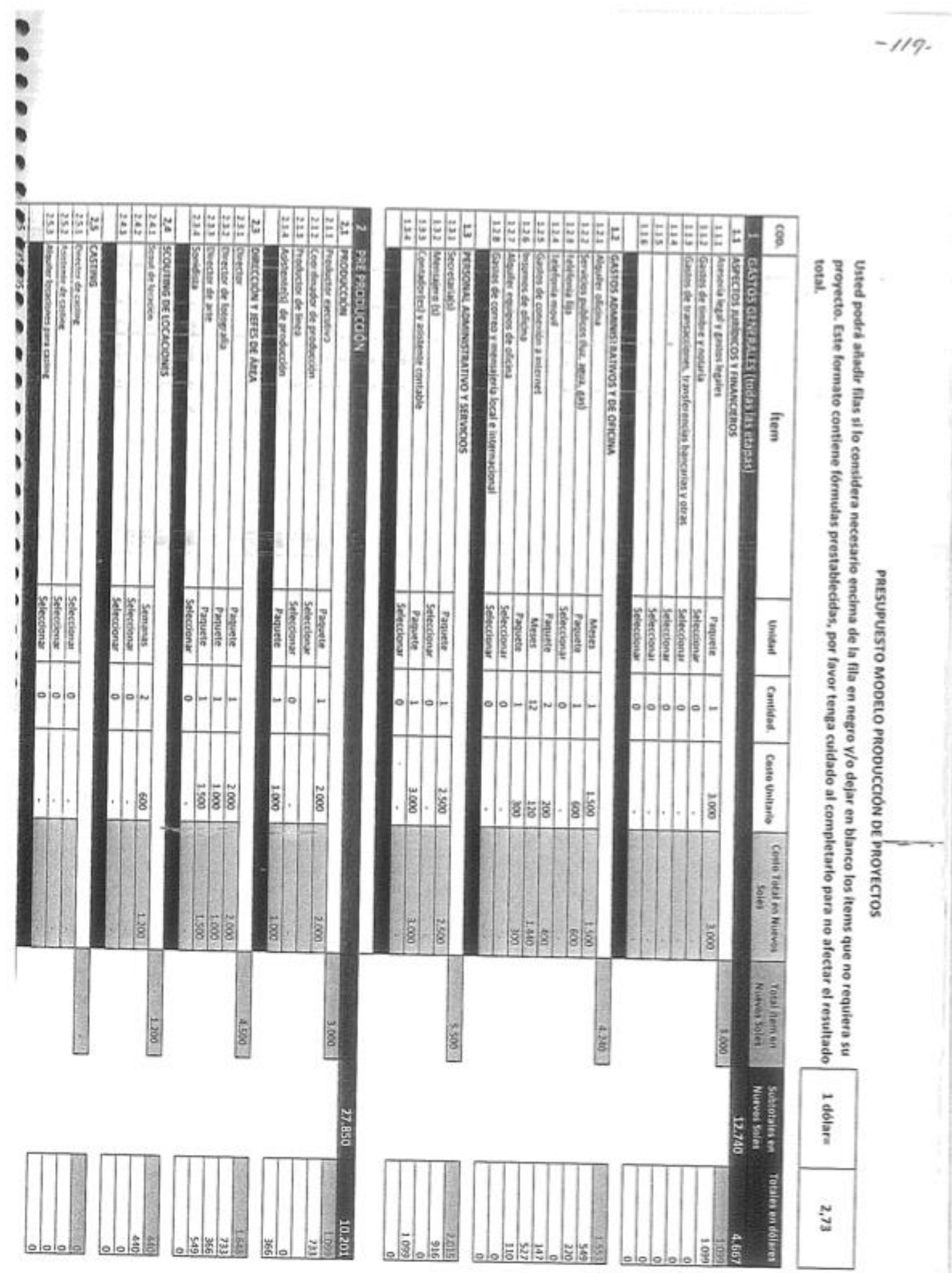




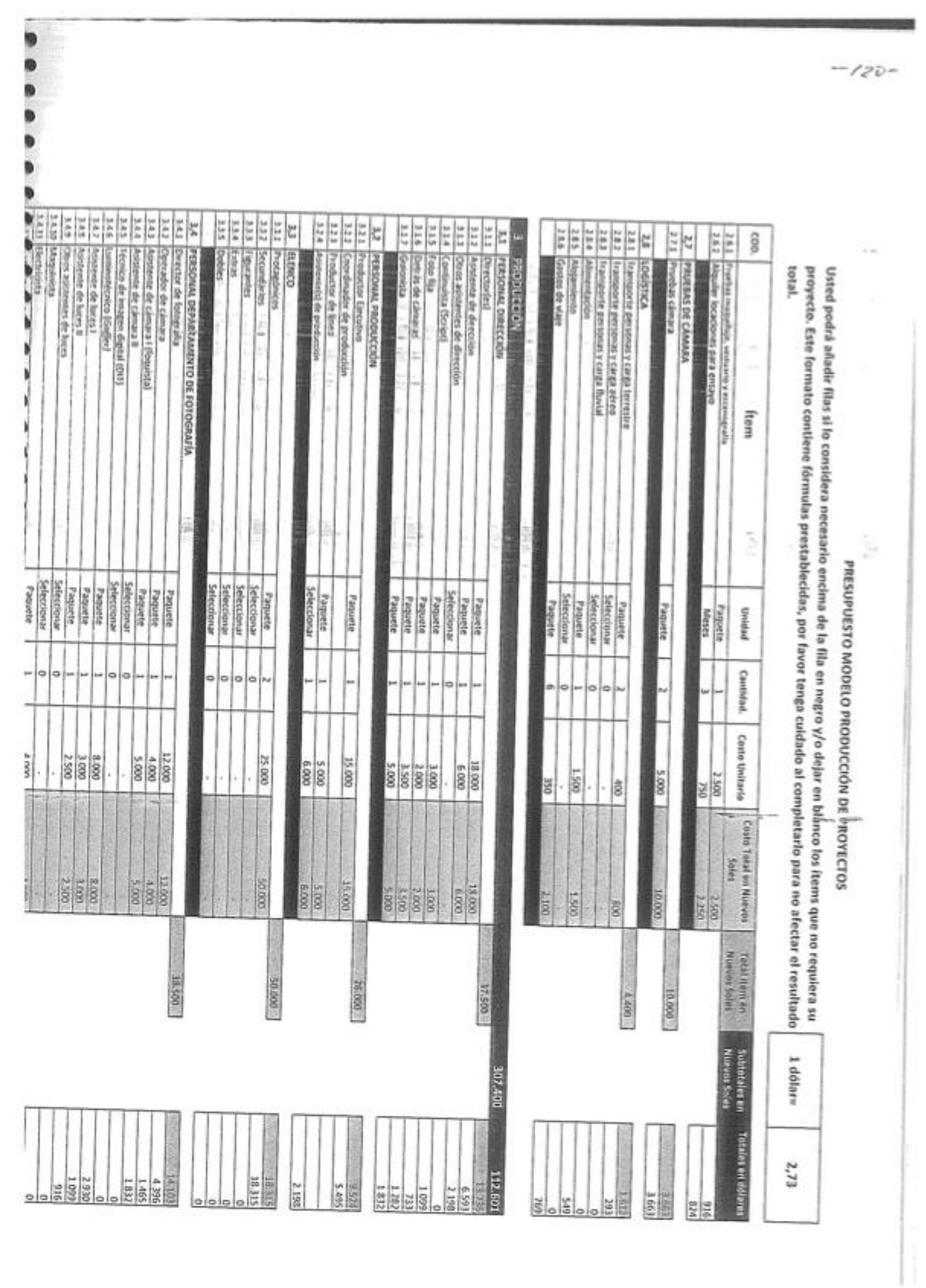




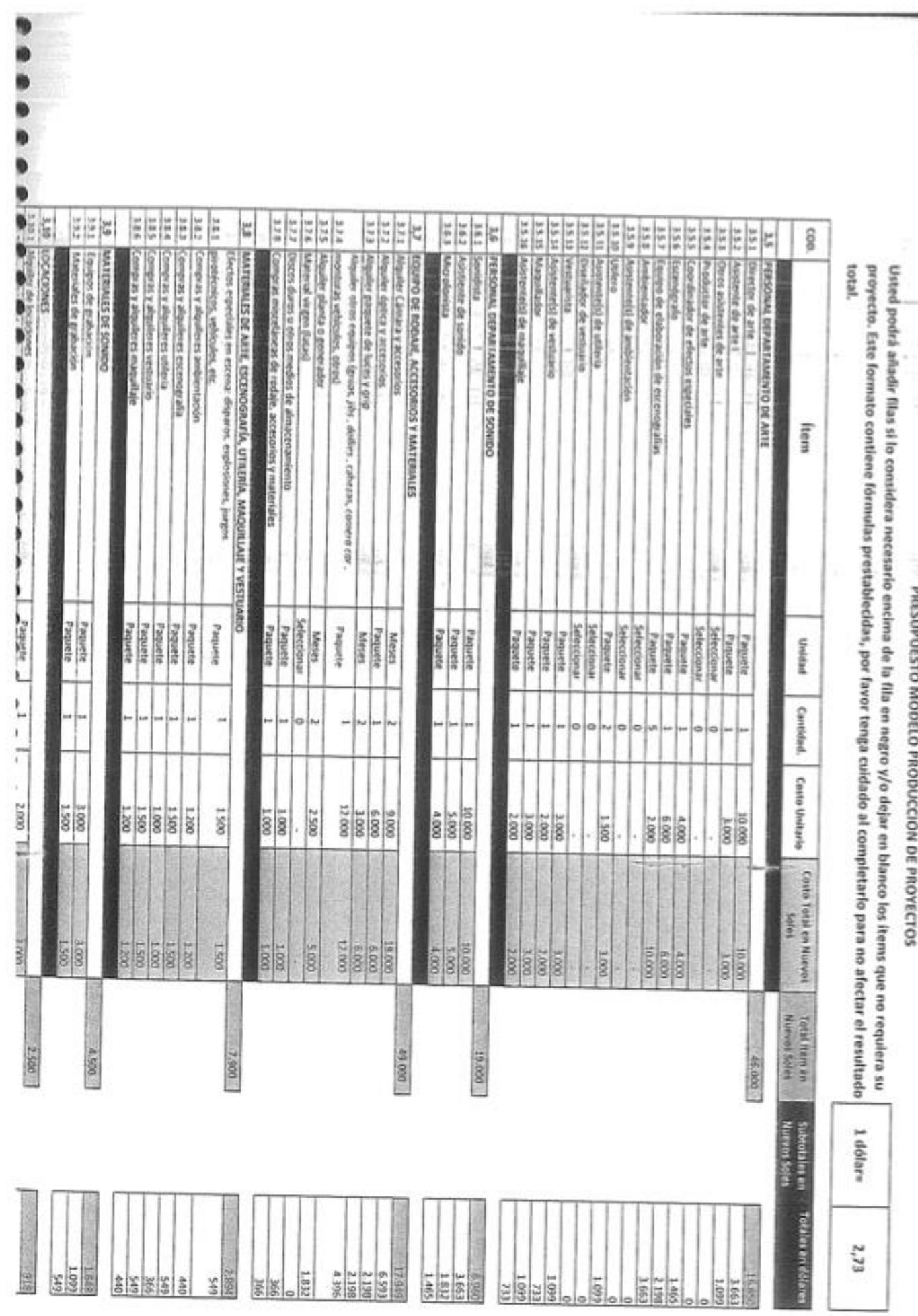




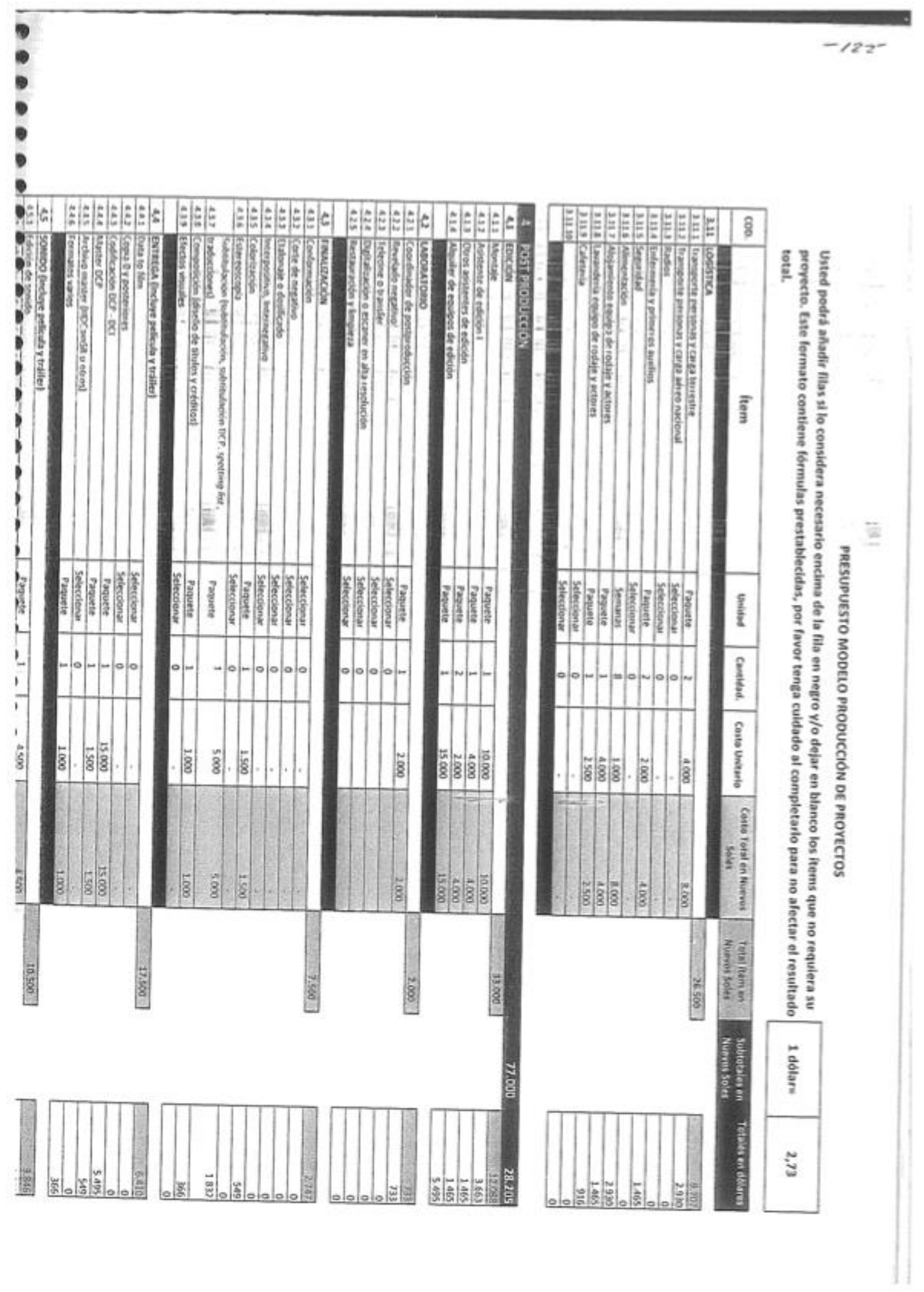




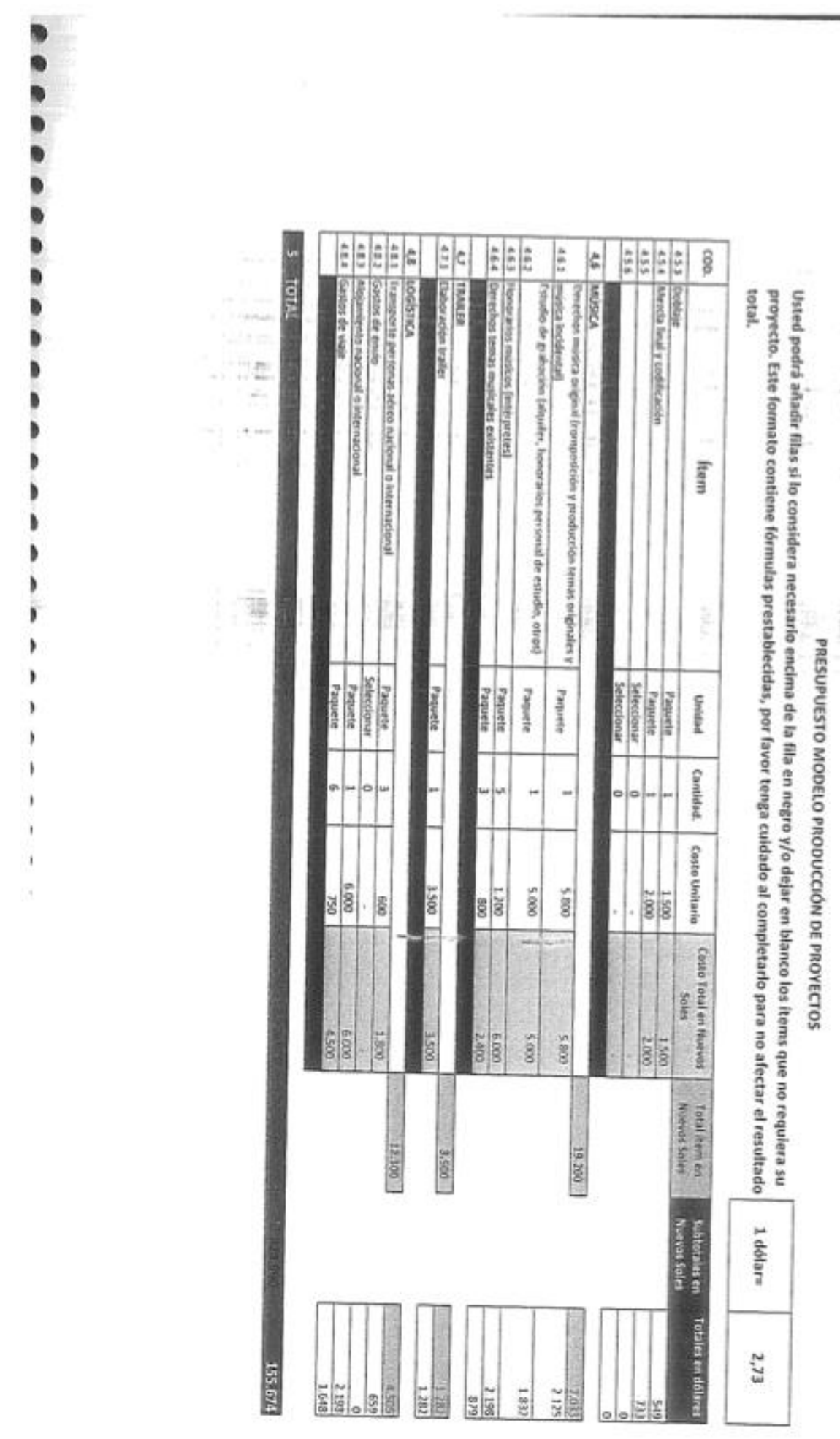


Chicama (2010)

\section{PRESUPUESTO DE PRODUCCION DE LARGOMETRAJE CHICAMA}

Formato de Filmación :

$\mathrm{S} 16 \mathrm{~mm}$

Pre-Producción (P):

Rodaje (R):

Edición(E):

Laboratorio(L):

\begin{tabular}{ll}
$\frac{8}{4}$ & $\begin{array}{l}\text { semanas } \\
\text { semanas } \\
\text { semanas }\end{array}$ \\
\hline$\frac{6}{3}$ & semanas
\end{tabular}

TOTAL DE LA PRODUCCION:

1US\$ $=\mathrm{S} / .3 .00$

21 semanas

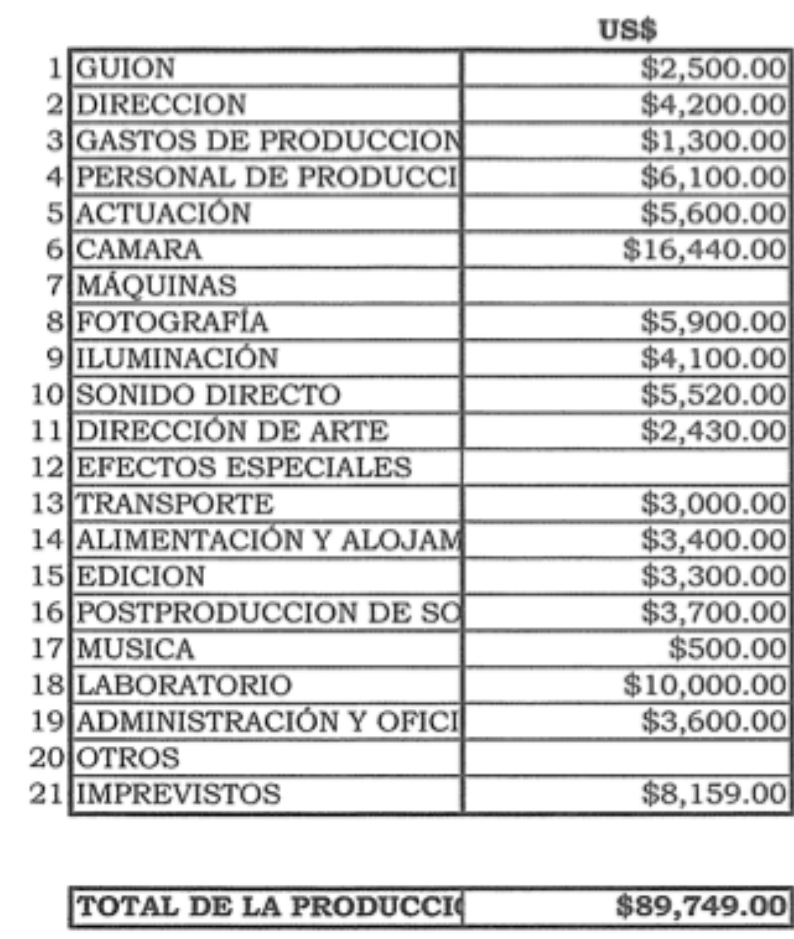

$\mathrm{s} /$.

S/. 7,500.00 S/. 12,600.00 $\mathrm{S} / .3,900.00$ $\mathrm{S} / .18,300.00$ $\mathrm{S} / .16,800.00$ S/. 49,320.00

$\mathrm{S} / .17,700.00$ S/. 12,300.00 $\mathrm{S} / .16,560.00$ S/. 7,290.00

$\mathrm{S} / .9,000.00$ S/.10,200.00 S/. $9,900.00$ S/. 11,100.00 S/. $1,500.00$ S/. 30,000.00 $\mathrm{S} / .10,800.00$ S/. 24,477.00

Porcentaje

\begin{tabular}{|r|}
\hline $2.79 \%$ \\
\hline $4.68 \%$ \\
\hline $1.45 \%$ \\
\hline $6.80 \%$ \\
\hline $6.24 \%$ \\
\hline $18.32 \%$ \\
\hline $6.57 \%$ \\
\hline $4.57 \%$ \\
\hline $6.15 \%$ \\
\hline $2.71 \%$ \\
\hline $3.34 \%$ \\
\hline $3.79 \%$ \\
\hline $3.68 \%$ \\
\hline $4.12 \%$ \\
\hline $0.56 \%$ \\
\hline $11.14 \%$ \\
\hline $4.01 \%$ \\
\hline $9.09 \%$ \\
\hline
\end{tabular}

S/.269,247.00

$100 \%$ 


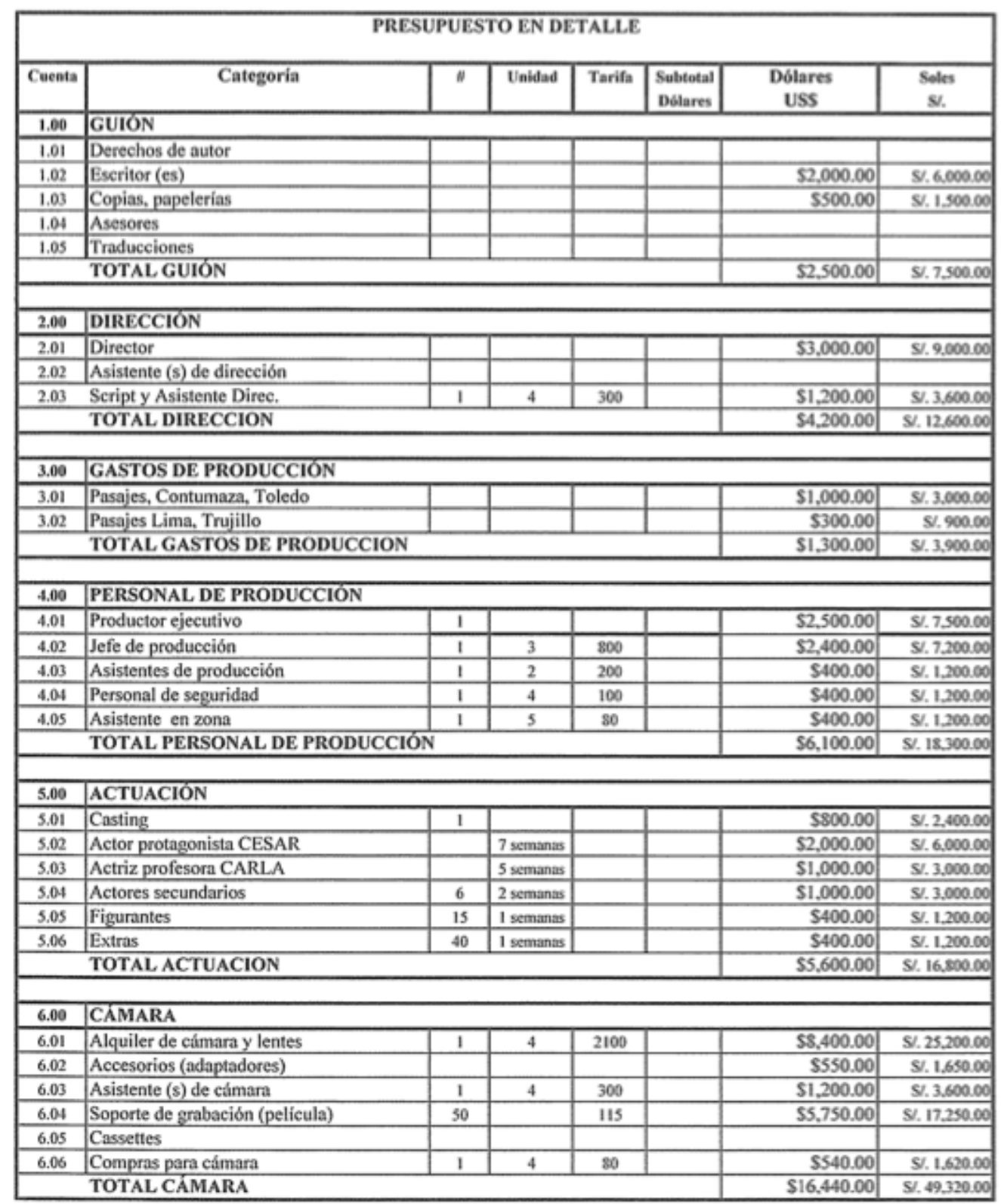




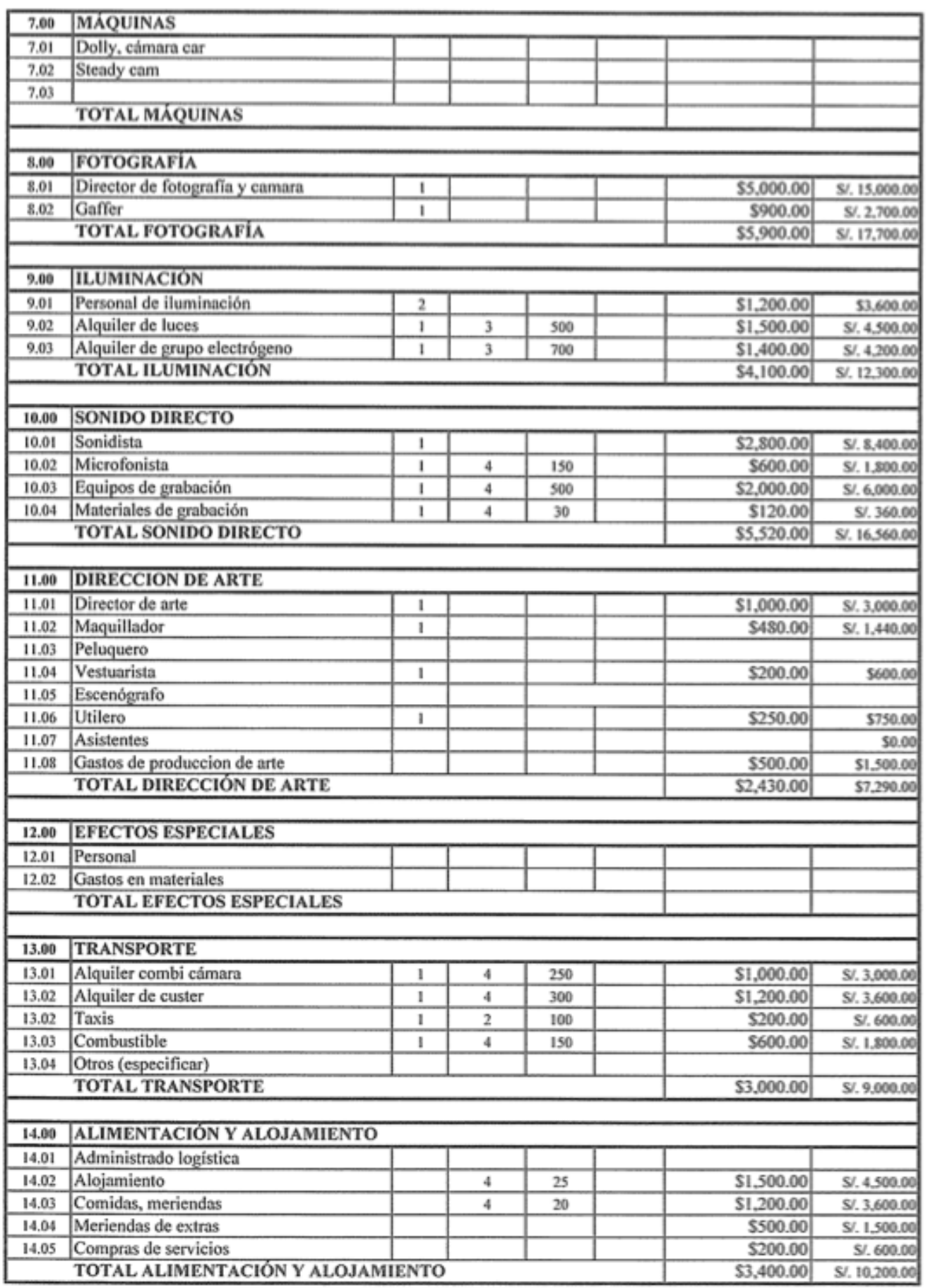


15.60 EDICION

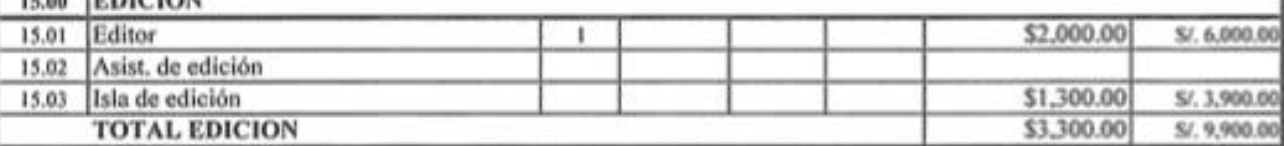

16.00 POST PRODUCCION DE SONIDO

16.01 Post productor de sonido

\begin{tabular}{|c|l|l|l|r|r|}
\hline 1 & & & & $\$ 2.000 .00$ & $\$ .6000 .00$ \\
\hline
\end{tabular}

16.03 Fstudio de pastproduceien

de sonido

16.04 Doblajes y foley

16.05

16.06

TOTAL POST PRODUCCIÓN DE SONIDO

\begin{tabular}{|r|r|r|r|r|}
\hline & & & $\$ 2,000.00$ & $\$, 6.000 .00$ \\
\hline & & & & \\
\hline & & & $\$ 1,200.00$ & $\$, 3.3000 .00$ \\
\hline & & & & \\
\hline & & & & \\
\hline
\end{tabular}

17.00 MÚSICA

\begin{tabular}{|l|l|}
\hline 17.01 & Compositor \\
\hline 17.02 & Musicos \\
\hline
\end{tabular}

\begin{tabular}{l|l}
\hline 17.02 & Músicos \\
\hline
\end{tabular}

17.03 Estudio de grabación y mezcla

17.04 Derecho autoria Músical

17.05

17.06

TOTAL MÚSICA

$\$ 3,700.00 \quad \$, 11,100.00$

\begin{tabular}{|c|c|c|c|c|c|}
\hline 18.00 & \multicolumn{5}{|c|}{ LABORATORIO (detallar proceso hasta primera copia) NUEVOS MONTOS } \\
\hline 18.01 & \multirow{2}{*}{$\begin{array}{l}\text { Revelado y preparado para transfer } \\
25 \text { horas de transfer a spirit }\end{array}$} & 50 & 60 & $\$ 3,000.00$ & $\$ .9 .000,00$ \\
\hline 18.02 & & & & $\$ 7,000.00$ & SI.21.000.00 \\
\hline & \multicolumn{2}{|l|}{ TOTAL LABORATORIO } & & $\$ 10,000.00$ & S. 30.000 .00 \\
\hline
\end{tabular}

19.00 ADMINISTRACION Y OFICINA

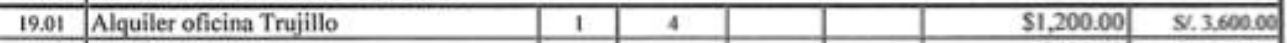

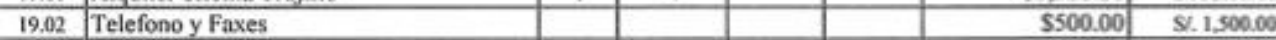

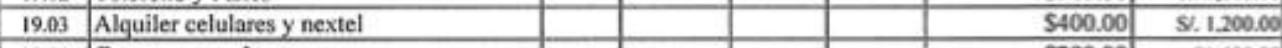

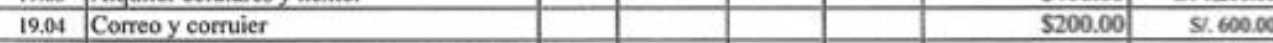

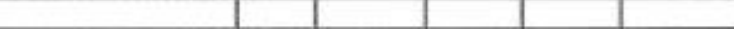

\begin{tabular}{|l|l}
\hline 19.05 & Administrador \\
\hline 19.06 & Contador \\
\hline
\end{tabular}

19.06 Contador

19.07 Compras de oficina TOTAL ADMINISTRACION Y OFICINA

\begin{tabular}{|l|l|}
\hline$\$ 500.00$ & $\$ / 1.500 .00$ \\
\hline 5500.00 & $\$ \%, 1.500 .00$ \\
\hline
\end{tabular}

\begin{tabular}{|r|r|}
\hline 5500.00 & $\$ .1 .500 .00$ \\
\hline 5300.00 & $\$ .90000$ \\
\hline 53.600000 & $\$ .10 .800000$ \\
\hline
\end{tabular}

\begin{tabular}{|c|c|c|c|}
\hline \multirow[t]{2}{*}{20.60} & OTROS & & \\
\hline & $\begin{array}{l}\text { (Búsqueda de coproducción, } 2^{\circ} \text { unidad, } \\
\text { rodaje fuera del pais, ete.) }\end{array}$ & & \\
\hline \multirow[t]{2}{*}{21,00} & IMPREVISTOS & & \\
\hline & & $\$ 8.159 .00$ & $\$ 24,477.00$ \\
\hline \multicolumn{2}{|c|}{ GRAN TOTAL } & $\$ 89,749.00$ & $\$ 269,247.00$ \\
\hline
\end{tabular}


